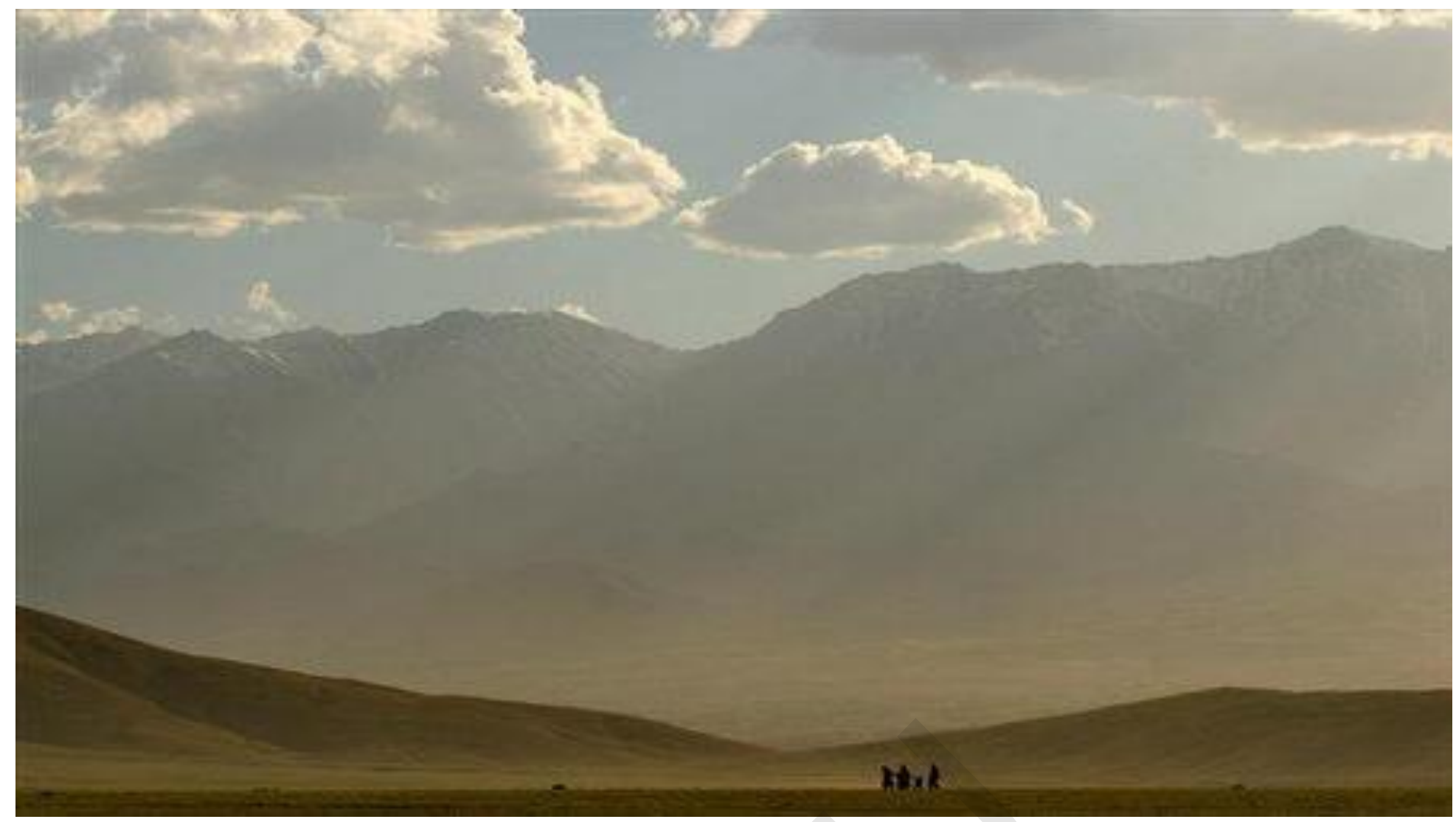

FINAL REPORT@

Department for International Development

Afghanistan

Helmand Justice Mapping Study

PO: 5272

Sarah Ladbury, in association with

Co-operation for Peace and Unity (CPAU)

Deborah Smith

July 2010

\title{
coffey ${ }^{\mathcal{P}}$ international development




\section{coffey ${ }^{\curvearrowright}$ international development

FINAL REPORT (C)

Department for International Development

Afghanis tan

Helmand Justice Mapping Study

PO: 5272

Sarah Ladbury, in as sociation with

Co-operation for Peace and Unity (CPAU)

Deborah Smith

July 2010

Coffey International Development Ltd

The Malthouse 1 Northfield Road Reading Berkshire RG1 8AH United Kingdom

T (+44) (0) 1189566066 F (+44) (0) 1189576066 www.coffey.com/internationaldevelopment

Registered Office: 1 Northfield Road Reading Berkshire RG1 8AH United Kingdom

Registered in England No. 3799145 Vat Number: GB 724530945 


\section{ABBREVIATIONS AND ACRONYMS}

\begin{tabular}{|c|c|}
\hline AlHRC & Afghan Independent Human Rights Commission \\
\hline ANA & Afghan National Army \\
\hline ANP & Afghan National Police \\
\hline ASOP & Afghan Social Outreach Programme \\
\hline CCs & Community Councils \\
\hline CPAU & Cooperation for Peace and Unity \\
\hline DC & District Council \\
\hline DCOP & District Chief of Police \\
\hline DG & District Governor \\
\hline DoWA & Department of Women's Affairs \\
\hline FOB & Forward Operating Base \\
\hline GIRoA & Government Islamic Republic of Afghanistan \\
\hline HIBP & Helmand Institutions Building Programme \\
\hline ICWCR & Independent Commission on Women and Children's Rights \\
\hline IDLG & Independent Directorate of Local Government \\
\hline ISAF & International Security Assistance Force \\
\hline JSC & Justice Sub-Committee (of Community Council) \\
\hline JSSP & Justice Sector Support Programme (US) \\
\hline LKG & Lashkar Gah \\
\hline MOJ & Ministry of Justice \\
\hline NDS & National Directorate of Security \\
\hline PRS & Prisoner Review Shura \\
\hline PRT & Provincial Reconstruction Team \\
\hline TAF & The Asia Foundation \\
\hline WADAN & Welfare Association for the Development of Afghanistan \\
\hline
\end{tabular}




\section{CONTENTS}

1

EXECUTIVE SUMMARY

1.1 Main Findings iii

1.2 Recommendations vii

1.3 A Note on Indicators xiv

$\begin{array}{ll}\text { INTRODUCTION } & 1\end{array}$

$2.1 \quad$ Background 1

$2.2 \quad$ Aims of this Study 2

2.3 The Afghan Policy Context 3

$2.4 \quad$ Evidence Base and Methodology 3

$\begin{array}{lll}2.5 & \text { Acknowledgements } & 4\end{array}$

$2.6 \quad$ Organisation of this Report 4

3 DISPUTE RESOLUTION IN HELMAND: FINDINGS FROM THE MAPPING STUDY

$3.1 \quad$ Terminology 5

3.2 Dispute Resolution: In Government Controlled Areas $\quad 6$

3.2 Dispute Resolution: In Taliban Controlled Areas 8

3.4 What Happens When Women Have a Dispute/Problem? 9

$\begin{array}{lll}3.5 & \text { Summary } & 10\end{array}$

$4 \quad$ PERCEPTIONS OF FAIRNESS OF DIFFERENT SYSTEMS 12

4.1 Perceptions of Fairness (i) Community Based Dispute Resolution 12

4.2 Perceptions of Fairness (ii) the 'Government' System 13

4.3 Perceptions of Fairness (iii) Taliban Dispute Resolution Mechanisms $\quad 15$

$\begin{array}{lll}4.4 & \text { Summary } & 17\end{array}$

$5 \quad$ REVIEW OF CURRENT PROGRAMMES OF SUPPORT 18

$\begin{array}{lll}5.1 & \text { The justice work of Community Council } & 18\end{array}$

$\begin{array}{lll}5.2 & \text { Summary } & 22\end{array}$ 
5.3 Prisoner Review Shuras (PRSs)

$5.4 \quad$ Summary 26

$6 \quad$ IMPLICATIONS OF STUDY FINDINGS: FREQUENTLY ASKED QUESTIONS

6.1 What are the characteristics of the different dispute resolution mechanisms operating in rural Helmand? What is working best and for whom?

6.2 What would persuade people to stop using the Taliban system? 28

6.3 There is clearly a difference between women and men's experience of the 28 justice system. What is the crux of the issue here - and what can be done to increase women's access to justice?

6.4 Are the Justice Sub Committees and Prisoner Review Shuras well thought of and understood? Is current support having an impact on people's ability to access fair justice?

6.5 Is current DFID and PRT supported work on justice in Helmand aligned with the draft national policy? What future approaches/actions might help align UK support even more closely with policy principles?

6.6 Do findings of the mapping study point to any particular issues that the draft policy Working Group might want to consider as the draft policy informs the new law?

6.7 What do study findings say about justice indicators that might be used for the Helmand Institution building Programme supported by DFID?

\section{APPENDICES}

A ADDITIONAL INFORMATION ON TYPES OF DISPUTES AND JUSTICE ACTORS 


\section{EXECUTIVE SUMMARY}

\section{Aims of the Study}

This study maps how men and women in Helmand get justice, focusing particularly on how they resolve disputes. By focusing on the experience and perspectives of men and women in Helmand villages it provides a bottom up view of what has to change if ordinary people are to access justice mechanisms, and see them as fair. The focus is on the 'informal' systems of dispute resolution (involving Elders and Mullahs) and how they link with 'formal' statutory processes (prosecutors, defence lawyers, judges and courts) for both civil and criminal litigation. The mapping study, together with findings from other data sources, enables an assessment of current government and international efforts to strengthen and link community-based and statutory justice mechanisms.

The study concentrates on disputes between non-state parties, (e.g., households, neighbours and villages) rather than disputes between citizens and the state (e.g., the police). Although many respondents commented on disputes involving the police, these are not a primary aspect of the analysis because they do not involve the community based dispute mediation processes that are the focus of this study.

The study also focuses on adults rather than children. Respondents in the mapping study mentioned children's lack of access to justice in two main contexts: with regard to the forced marriage of very young girls and the abduction of young boys for sex with men. We report respondent's attitudes to these practices but do not focus on children's justice more generally.

The study has three specific aims:

- to map how men and women get disputes resolved in rural Helmand;

- to review the contribution of UK support to the justice work of Community Councils (CCs) supported under the Afghan Social Outreach Programme (ASOP), and to Prisoner Review Shuras (PRS); and

- to provide recommendations to inform future action and programming in the justice sector.

\section{Political Context}

Security and justice are priority demands of Afghanistan's population. Although the Taliban provide very few other services, they do provide security and justice in areas they control. This study (confirming the results of prior research) suggests that although Taliban justice is not universally liked, it is accessible, speedy and free, and so it garners a degree of local support. Building the capacity of non-Taliban justice actors, both state and non-state, is therefore seen as an important contribution to wider counter-insurgency strategies.

Building public trust in the government through the provision of a basic service like justice is not straightforward in Helmand. Most ordinary people do not make a distinction between the government and the judiciary and associate the government with practices and behaviours they dislike: the inability to provide security, dependence on foreign military, eradication of a basic livelihood crop (poppy), and as having a history of partisanship (the legacy of Bonn and perceived preferential treatment of northerners). Many years of sporadic but ongoing violent conflict, the loss of Afghan lives, and the fact that many local men are themselves involved in the fighting, including as local Taliban and members of narcotics militia, militates against a sense of central government allegiance. ${ }^{1}$ The fact that the state justice sector also has significant weaknesses and is absent from large swathes of Helmand, and the Taliban provide a non-state alternative, are major additional challenges, but local communities question the legitimacy of government and the intentions of international forces anyway. Study respondents' perceptions of justice processes associated with government should be seen in this light.

\footnotetext{
${ }^{1}$ These recent factors compound an historical lack of allegiance to a central state authority. 


\section{Policy Context and UK Assistance}

The Government of the Islamic Republic of Afghanistan (GIRoA) is currently developing a new law to link community based dispute resolution mechanisms and the statutory justice system. In November 2009, a Ministry of Justice Working Group produced a 'Draft National Policy on Relations between the Formal Justice System and Dispute Resolution Councils', which is now being used as the basis for developing the new law. This study is intended to inform the Core Working Group supporting the development of this law.

The UK assistance programme to Afghanistan now has a significant focus on justice and brings experience from Helmand to the policy process; it participated in the Ministry of Justice working group on the draft national policy. The Rule of Law team in the UK led Helmand Provincial Reconstruction team (PRT) works to strengthen GIRoA's ability to deliver justice through both statutory and community based justice mechanisms, seeking opportunities to bridge the two. This study is intended to inform ongoing PRT justice work, particularly that focusing on community based justice. It does not give a comprehensive analysis of the statutory sector although it is difficult to examine communitybased justice without at least a superficial examination of the statutory system because of links between the two. (A comprehensive analysis of the statutory sector is planned, and is recommended.) This study is also intended to inform baselines around justice for the Helmand Institutions Building Programme (HIBP) - a four-year DFID supported programme begun in December 2009, aimed at helping to build enduring and accountable Afghan institutions in the province.

\section{Evidence Base}

The findings in this report are based on several sources: the mapping study, which interviewed 269 people in rural Helmand, just over half $(51 \%)$ of whom were women; interviews with justice policy makers, providers and partners in Government, civil society and the international community; and existing reports and information on the justice sector in Afghanistan.

The findings of the mapping study should be seen as illustrative rather than representative. Whilst efforts were made to ensure a diverse group of respondents in terms of age and background, the volatile security situation and time available for fieldwork did not permit representative sampling.

\section{Terminology}

In this report, the term 'community-based mechanisms' refers to dispute resolution mechanisms adjudicated by Elders and Mullahs; the term 'statutory system' is used to describe the formal court system. The term 'Taliban mechanisms' refers to dispute resolution processes administered by the Taliban in areas they control.

Respondents in the mapping study used an additional terminological category. They tended to bundle all government and statutory justice actors together and call them 'the government system'. This designation included District Governors and District Chiefs of Police and state justice personnel (prosecutors, judges, defence lawyers, civil dispute mediators). We use the term 'government actors' when reporting what respondents said about this broad category of actors.

\footnotetext{
${ }^{2}$ The tendency of the public to conflate the court system with the executive branch of government in Helmand, with the perception they are one and the same, is also noted by Fearon, 'Informal Justice at District Level in Helmand Province'. June 2010 
MAIN FINDINGS

\subsection{On How Citizens Access Justice in Helmand}

1 Steps in dispute resolution. The first port of call for the vast majority of disputes in Helmand is the community-based system: local (village-based) Elders and Mullahs. They tend to hear all types of civil and criminal cases, i.e. including those where violence and killings have occurred. The community-based system therefore effectively resolves the majority of disputes across the province, in both government and Taliban controlled areas.

\section{If cases are not resolved at a local level then District Governors - and Taliban}

Commanders in Taliban controlled areas - are the next port of call. District Governors resolve some cases personally but will also refer cases to district level Community Councils or to the statutory system. Taliban Commanders will resolve some cases and refer others on, either to designated mullahs, to mobile courts or to Taliban district judicial committees, depending on Taliban justice arrangements in the area.

3 The statutory system - prosecutors, judges and courts - is the final step in dispute resolution for those living in areas under government control. Its presence outside Lashkar Gah is limited but gradually increasing as Prosecutors and the Huquqs (from the civil affairs department of the Ministry of Justice) take up their posts in district centres.

$4 \quad$ There is an additional 'step' for civil cases in some districts. This is provided by the Elders elected to Community Councils under the government-led Afghan Social Outreach Programme (ASOP). Community Councils function as a last chance for civil cases to be resolved before being referred to the statutory system.

$5 \quad$ Links between the different systems. There have always been links between different dispute resolution mechanisms in the sense of referrals between them. They are normally sequenced so that disputants seek community-based mechanisms first, if this does not work, they go to the District Governor and if this does not work, he will refer them to the statutory system. However, cases can also go back and forth between all three groups of actors. Taliban processes also use Elders and Mullahs to resolve disputes. They also allow disputants to come and consult government facilities, particularly Records Offices, in order to collect evidence for their claims.

$6 \quad$ With few exceptions, women have no independent access to justice in Helmand; they take no part in community-based mechanisms or statutory systems as disputants or decision makers. The vast majority of women in Helmand rarely leave their households and dare not take their problems to anyone outside their immediate family for fear of retribution by family members (an honour issue). Only a tiny number of women work in public positions - as teachers, women police or in NGOs. Women's lack of voice in dispute resolution is therefore a reflection of their lack of autonomy in society as a whole but it also reflects on the lack of action by justice bodies, state and non-state, to include them.

$7 \quad$ Many women respondents had strong views about what needs to change for women and children but no channel to express them. Women directed some complaints at reconciliation judgements by Elders and Mullahs, for example, giving a girl in marriage to reconcile parties after a killing (a practice known as bad) or giving a girl to the family of a creditor in lieu of an unpaid debt. More generally, they complained about their lack of access to any form of justice support due to the restrictions imposed by their families and their lack of say about everyday practices that affected their wellbeing - a reflection of the absolute authority of men in defining community and tribal norms. When asked what would have to change for dispute resolution to be fair to women and children many women said 'education', others pinpointed the problem specifically and said 'the attitudes of our men'.

8 The Gereshk 'Women's Shura' is an example of the type of support women need to make their cases public. Currently a women's shura exists in only one district (Gereshk) but the model it provides is positive. It shows women will access dispute resolution processes if they have support from other women to do this. 
9 Principles used to resolve cases. Cases are decided according to principles that take their legitimacy from a number of different sources.

- Judgements by Elders and Mullahs rely on Pashtunwali, Shari'a and local custom/precedence. Pashtunwali and Shari'a can conflict; the first aims to reconcile conflicting parties through restoring a sense of equilibrium between them, Shari'a aims to give individuals their rights under Islam. In Helmand Pashtunwali normally dominates - both because male disputants are familiar with it and place a high premium on reconciliation, and because rural mullahs tend to be insufficiently versed in Shari'a (and sometimes not senior enough in the local hierarchy) to influence decisions. Only when senior Islamic scholars (Ulema) are called in to adjudicate a case is Shari'a certain to be used as the main resolution principle.

- Judgements in the statutory system rely on the many laws and decrees passed in Afghanistan over the last 50 years. Judges in Helmand have access to legal texts but they do not always have the knowledge, competence, or ability to read and interpret them. In this case, they will apply what they know of the law and their own version of Shari'a.

- Although they have no formal justice role, District Governors also mediate cases and sometimes resolve them. They may draw on their own understanding of the law and Sharia but as far as we could ascertain none have any legal training.

10 Human rights. Very few of the thousands of Elders and Mullahs that adjudicate cases in the community system in Helmand have had an opportunity to understand what 'human rights' covers and the extent to which they judgements they make now do or do not conform to Shari'a, Afghan law and international human rights standards. Some of the solutions they currently offer that conform to Pashtunwali principles - the giving of a girl in bad for example - are contrary to all three. Since 2007, there have been a number of training courses on rights for community-based mediators run by different agencies, both state and non-state at provincial level. ${ }^{3}$ However, we could find no information about the outcomes of past courses. The extent to which greater awareness changes dispute mediation practices and outcomes will need to be monitored in future.

A major issue going forward is how to increase awareness of human rights amongst current and future Elders in rural Helmand. This would be most effective if done in a way that builds on rural people's understanding of rights, i.e. framing the discussion in terms of rights under Islam in the community context. ${ }^{4}$

\subsection{On Perceptions of the Fairness of Different Justice Systems}

1. None of the above systems, either singly or in combination, was seen as delivering fair justice to men, women or children.

2. Community-based mechanisms (dispute resolution jirgas held by Elders and Mullahs) are the most familiar and trusted justice mechanisms in Helmand. However, they have weaknesses. Men say that nowadays decisions made by Elders cannot always be enforced; those disliking a solution look around for alternative mechanisms that might result in a different judgement. Women say that although Elders and Mullahs are fair when they resolve disputes over land, water, property claims etc., they are not at all fair when they use women or girls to settle disputes. The statutory system is the least trusted due to lack of access, the frequent need for bribes, and the fact that justice decisions can be influenced by those with money or political power. Government actors (such as District Governors and District Administration officials) were seen as accessible in district centres but also open to bribery and partisanship. Although Taliban justice mechanisms are seen as quick and bribe

\footnotetext{
${ }^{3}$ These have involved different GIRoA departments and both government and civil society trainers and facilitators. For example, the Huquq Department of the MoJ led three Legal Education Shuras in 2009; the regional AlHRC organised a training programme for the Provincial Ulema Shura in late 2008/early 2009; JSSP are about to run a course to build the capacity in criminal justice.

${ }^{4}$ This is consistent with the plan of human rights activities which had been agreed between the Regional Office of AlHRC and the Provincial Governor of Helmand in August 2008, and the initial work carried out on the implementation of the plan.
} 
free, they are experienced as control mechanisms with harsh judgements that do not reflect Afghanistan's Hanafi-based Shari'a traditions. A common view was that the Taliban 'aren't really interested in justice, they just use justice as a means of control'.

3. Men and women want a justice sector that has internal integrity. That is to say they want decisions made by lower level authority (e.g. at village level) to be backed by decisions made by higher-level authorities (e.g. the statutory system). This does not always happen at present: as noted, if one party is unhappy with a resolution offered by the Elders they may go to the DG or even directly to the court in Lashkar Gah hoping to get a judgement that better suits their interests. Respondents wanted decisions to be final.

4. Women and men can have different priorities when it comes to the principles on which they think cases should be adjudicated. The fact that women in Helmand are enormously restricted in their mobility does not mean that they have no opinions on how they think justice systems need to change. The more outspoken women interviewed were strong supporters of rights based justice - this was expressed as support for Shari'a because this is what they know. Men are more inclined to support the principles inherent in Pashtunwali, i.e. reconciliation and the maintenance of group honour.

5. Bad has received a great deal of attention in Afghan and international justice debates, and is still routinely used in some Helmand districts to resolve disputes that involve killings. Most women interviewed wanted the practice to stop and some men also said it should be abolished. They said it was unfair on girls and because they were often badly treated (they were seen as coming from the enemy camp), bad could actually increase rather than decrease enmity between families.

6. However, a single emphasis on bad detracts from the large number of other practices that women feel discriminate against them and disregard their children's wellbeing. For example, domestic violence; forced marriage; multiple marriages (by men) and the unequal treatment of co-wives; being forced to demand inheritance from natal families; marriage to very old men in return for high brideprice payments or to a creditor in lieu of an unpaid debt. Many such practices were not to do with the justice system per se but as some women put it to 'the attitudes of our men'. Nonetheless, the fact that the justice sector does not give women and children accessible channels for support and complaint about such practices makes it a justice sector issue.

\subsection{On the Impact of UK Support to the Justice Work of Community Councils and to Prisoner Review Shuras}

\subsubsection{The Justice work of Community Councils (CCs)}

1. Community Councils comprise elected Elders that meet regularly in the district centre to discuss issues arising in their three designated areas of responsibility, including justice. They are intended as temporary transition bodies, and as the pre-runners of District Councils, which will come into being under a Sub-National Governance Act (based on the current Sub-National Governance Policy).

2. Community Council Justice Sub-Committees are now achieving some of their basic objectives. They are hearing and resolving minor civil cases; one district has shown that if women are elected to CCs it can increase the access of women to justice; and links between the JSC/CC, District Governors and statutory justice actors are strong, indicating that justice actors can link successfully at district level.

3. UK support to CCs to date has focused mainly on getting them up and running as institutions. So far, their members have had little training on legal concepts and human rights issues and the ASOP team have not prioritised women and children's justice to date. Yet Community Council members are an accessible audience for training on basic legal concepts and women and children's rights; a future phase of UK support needs to capitalise on this. 
4. So far, there has been limited outreach to the hundreds of mullahs and elders acting as mediators in villages. A good start was made in reaching out to village Elders in 2008: Legal Education Shuras ${ }^{5}$ were held in Lashkar Gah, Gereshk and Garamsir led by the Huquq Department of the Ministry of Justice but this programme was not continued. Other training on human rights has been provided at provincial level - for example, the Provincial Ulema Shura organised through the regional Afghan Independent Human Rights Commission (AIHRC). However, programmes to date have not reached the vast majority of Elders and Mullahs at district level and in villages. ${ }^{6}$

5. The Justice Sub-Committees of Community Councils represent the supply side of dispute resolution; there also needs to be equivalent emphasis on allowing for expressions of demand. ${ }^{7}$ Two current PRT programmes begin to address this issue: PRT training for women police officers and core and training support to the Independent Commission on Women and Children's Rights (ICWCR). ${ }^{8}$ Both these groups - the ICWRC women's group and women police officers - currently meet and support women and girls who have problems but cannot access justice mechanisms; both groups have a role to play in future PRT programming.

6. There was a perception amongst some village based respondents that the initial Community Council elections were not carried out transparently; some respondents maintained the CC Elders were 'selected' not 'elected'. There were also allegations of financial misconduct in some districts, for example, around the resources given to CCs (wheat seed, fertilizer etc) for distribution by Social and Economic Sub-Committees to the poorest areas of districts. Allegations of unfair distribution practices and financial misconduct are a concern as they lessen the legitimacy of CCs and may undermine public trust in their functions, including justice. If not addressed through transparent procedures they could undermine the ability of CCs to have a watchdog role, and to be seen as fair and impartial dispute mediators.

7. CCs are relatively new institutions. Progress against their wider justice objectives has inevitably been constrained by existing capabilities, the constraints of operating in a highly insecure environment, and the fact that DFID and the PRT provide high quality - but currently only limited support.

\subsubsection{Prisoner Review Shuras}

1. Prisoner Review Shura were set up with PRT support as temporary mechanisms to prevent wrongful arrests, detention beyond legal time limits and mistreatment in custody, as well as to prevent unlawful releases from custody. They involve meetings between Afghan security forces, the District Governor and a community member (JSC where present). The meetings are supported and mentored by internationals (ISAF or District Stabilisation Teams). They usually meet weekly to determine if there any evidence of a serious crime being committed by recently detained prisoners.

2. PRSs have had an impact: prisoners have been released when there is insufficient evidence to hold them and they have allowed for information sharing on suspects thereby preventing some unlawful releases. They have also helped establish certain principles: that the 72-hour detention rule should be respected; that relatives should be able to get information about detainees; that security forces should operate within the law.

\footnotetext{
${ }^{5}$ These shuras brought together village and district-centre level elders to learn, predominantly, about the different statutory sector institutions. Some inputs on women and children's rights and the Constitution were included.

${ }^{6}$ On the criminal justice side, district level training is in the pipeline: the US Justice Sector Support Programme (JSSP) will provide training for 110 statutory justice actors in Lashkar Gah, including some from districts. It is anticipated that this training will then be rolled out to districts, provisionally Nad-e Ali, Sangin and Nawa.

${ }^{7}$ The PRT Rule Of Law Governance Adviser post (Jan 2009-April 2010) included a demand-side remit but the post was discontinued in April 2010.

${ }^{8}$ There were 17 women police officers in Helmand in April 2010. They were playing a social protection role for girls running away from violence at home (in collaboration with the Department of Women's Affairs) and are potential interlocutors for women on justice issues more generally. The ICWRC are currently conducting a survey on women's experience and needs around justice.
} 
3. There were many internal disincentives to overcome in getting PRSs accepted and used. PRT District Stabilisation team members have consequently had to provide a great deal of hands on facilitation and mentoring to keep them going and make them work.

4. In districts where prosecutors have taken up their posts PRSs for criminal cases have stopped operating. However, prosecutors do not always have the political clout to get the cooperation of District Chiefs of Police. In retrospect, PRSs should probably have been continued until it was certain that prosecutors could take over their role. Continued operation would also provide a useful mechanism for ongoing coordination and information sharing between PRS members.

5. PRSs do not operate in Lashkar Gah due to the presence of the statutory justice sector. Arbitrary detention and unlawful releases remain an issue nevertheless.

6. PRSs could be criticised for being a foreign imposed mechanism. (They are not part of the statutory justice system but derive their authority from the participation and legal authority of the participants; they have been subsequently endorsed by the CCs in some districts). However, had community level respondents in the mapping study known about the PRSs (they did not) it is likely that they would have supported them - on the basis that any intervention that decreases arbitrary arrests and detentions by security forces, Afghan and foreign, is welcomed.

\section{RECOMMENDATIONS FOR A FUTURE PHASE OF UK SUPPORT TO JUSTICE IN HELMAND}

The following recommendations build on the extensive programme of support that the Helmand PRT already gives to the justice sector. In addition to support given to JSCs and the Prisoner Review Shuras the PRT supports a programme facilitating the transfer of Prosecutors and Huquq representatives to districts; police training; police mentoring; mentoring and training judges, prosecutors and defence lawyers; and (as mentioned) developing a women's paralegal network with the ICWRC. ${ }^{9}$

Existing UK support to the justice sector in Helmand is provided through the PRT Rule of Law and Governance teams. The community-based dispute resolution aspects form a component of the HIBP, which is DFID supported. The DFID programme in Kabul provides some support to the Rule of Law team and helps to bring the 'Helmand view' to negotiations in the national capital. The same is true of the UK Embassy in Kabul.

There is a need to ensure that future UK support to the justice sector is aligned with US justice sector support initiatives. ${ }^{10}$

Before outlining specific recommendations we suggest what a future programme of UK support needs to be able to do, and what its overall objectives might be.

\subsection{Future UK Support to the Helmand Justice Sector: Basic Requirements}

1. Current support needs to continue - both to Prisoner Review Shuras and the justice work of Community Councils. In addition to their justice functions these institutions provide a communication bridge between justice actors, community and statutory, and are a channel for relations with the PRT on justice issues. However, weaknesses perceived by the public with regard to CCs need to be addressed before District Councils take their place.

\footnotetext{
${ }^{9}$ PRT support to the justice sector also involves infrastructure, the building/completion of the LKG prison, LKG courthouse, LKG prison, and NDS Justice Centre/detention facility. A safe house/refuge for women and girls in LKG has been identified as a priority by the Department of Women's Affairs. This was also identified as a priority by Lashkar Gah women police officers. ${ }^{10}$ The US is by far the largest funder to the justice sector as a whole - USAID, State Department and the US Military are all involved. To date the US has not funded Helmand-specific programmes but Helmandi judges and prosecutors have participated in US supported national training courses. USAID also funded the building of the courthouse in LKG. The JSSP funded course anticipated at the time of fieldwork follows a JSSP supported conference in LKG in March 2010. The PRT Rule of Law team has been closely involved with this ongoing initiative and is in a position to learn lessons, help assess impacts and ensure alignment with future PRT and DFID funded programmes.
} 
2. Although this study has focused on the district level and below, a future strategy for the PRT in Helmand must involve a multi-pronged approach that operates at three levels: provincial, district and village, with links between them. This is essential to ensure that any work taken at one level - at village level for example - is complemented by and consistent with initiatives at district and provincial level.

3. A future programme would need to address both issues of supply - i.e. focus on the competence of dispute mediators, but also of awareness to stimulate demand. It is critical that the men, women and young people of Helmand know what their rights are, and how they can demand and realise them.

4. A future programme of support would be Afghan led and is an opportunity to build on and extend relationships between the PRT and Afghan justice actors. On the government side, this includes the provincial Department of Justice, the Huquq Department, the Attorney General's Office, the judiciary, the Department of Women's Affairs, the Land and Tribal Dispute Commission, the Department for Local Government, and in district centres District Governors, Chiefs of Police and Prosecutors and Huquq personnel. On the civil society side, PRT relations are well established with the Independent Commission for Women and Children's Rights (ICWCR), the Afghanistan Independent Human Rights Commission (AIHRC), WADAN (which provides logistics support for all the CCs) and research organisations with experience of reaching village communities, for example, Cooperation for Peace and Unity (CPAU) and ICWRC, which also operates in a research capacity.

5. Any emphasis on expanding awareness of rights amongst the population (the demand side) means that there is likely to be an important role for civil society in a future programme of justice sector support. There need to be mechanisms, networks and methods of communication that can extend down to village level. The Department of Women's Affairs (DoWA), ICWRC and the Gereshk Women's Shura already have contacts in some villages. Additional civil society contacts might usefully include senior religious figures including Qazi (Islamic judges), teachers, community media, and women police officers.

6. The lack of capacity within some government departments at provincial level and their absence at district level needs to be acknowledged. The same is true on the civil society side. PRT 'partnering' with an institution may therefore also involve - as it does now - helping to build its capacity and the expertise of staff. A participative mapping exercise involving some or all the parties mentioned in point 4 above would be useful. This would enable everyone to identify and share information about their respective mandates, capacity, expertise, level of working (provincial, district, village) and links with other organisations/departments, as well as what support they need to work more effectively.

7. A future programme of UK support in Helmand needs to be developed as part of a joined up UK strategy that involves all UK justice actors. These include the PRT Rule of Law, Governance and Counter-Narcotics teams, DFID Justice and Governance Advisers, the FCO Rule of Law team, and the British Military with regard to insurgency-related detentions and prosecutions. Close collaboration with the UK and US civilian military operation in Helmand and with US organisations already providing inputs (JSSP for example) would also be important.

\subsection{Proposed Objectives for Future UK Support}

Based on the findings of this study we recommend that a future programme of UK support has five objectives. It should aim to:

(i) Continue current support to the justice work of Community Councils and to Prisoner Review Shuras. Continuity of UK support to both institutions is important: they are critical 'bridging' mechanisms and the functions of both will become part of the remit for District Councils. Future support needs to include addressing weaknesses in CCs that lessen their legitimacy and extending PRSs to newly cleared areas. 
(ii) Increase the access of women and children to justice. The vast majority of women in Helmand do not have independent access to dispute resolution mechanisms - the best way to increase their access is through women intermediaries. Programming could build on the model offered by the Women's Shura in Gereshk but would also look for other ways to achieve the same result.

(iii) Increase the awareness of $\mathrm{JSC} / \mathrm{CC}$ and community mediators around human rights and how to apply these in dispute mediation. CCs are an initial entry point for training on legal concepts and human rights, but approaches need to be identified to convey messages and discussions to the large number of Elders and Mullahs at village level. This needs to be done within an Islamic framework as this is what Elders and Mullahs respect and are familiar with.

(iv) Improve links, accountability and oversight between the statutory and community systems. This relates to the Draft National Policy and upcoming law that will outline the links between community-based dispute resolution mechanisms and the statutory justice system. Study findings suggest ways in which these mechanisms might link and how oversight might be applied.

(v) Continue and strengthen UK support to the statutory justice system, particularly around issues of accountability, women's access to justice and countering corruption. Support to community-based mechanisms alone is not enough - there needs to be a strong, reliable and accountable statutory system on which community members can rely, at both provincial and district level. The findings of this study point to the need to improve significantly transparency and accountability in the statutory sector in order to improve public trust in its operation. The mapping study shows that currently, public trust in government and statutory justice processes is low. In particular, the issue of informal payments needs to be dealt with as part of capacity development programmes, and programmes seeking to improve the transparency of systems and procedures.

The paragraphs below take the first three objectives and suggest how they might be achieved through a next phase of programming. The suggestions given are illustrative - given that any future programme would need to be developed following consultations with those who will lead, design, implement and monitor each programme component. Points made under the fourth objective are addressed to the Core Working Group on the Draft National Policy; they are currently supporting the development of the new law that will define the relationship between community-based mechanisms and the statutory justice system. The fifth objective - concerning future support to the statutory system - needs to be the subject of a separate review by statutory justice specialists. The intention here is to highlight its importance and to emphasise that community based and statutory justice are complementary components of the total justice sector - both need strengthening if Helmand's population is to get justice.

\subsubsection{Objective 1: Increase Public Trust in the Justice Work of CCs and Extend Prisoner Review Shuras to Newly Secured Areas}

With regard to CCs, we recommend:

1. The ASOP Planning team ensure that future $\mathbf{C C}$ elections are widely publicised and electoral college procedures made wholly transparent. This will help ensure the public see elections as fair and the Elders elected as representative. The recent election in Nad-e Ali is a positive example.

2. The ASOP Planning team take steps to make all CC financial decisions transparent including the disbursement of seeds and fertilizer that goes through the CC Social and Economic Development sub-committee. Although not a justice issue, allegations of financial misconduct impact on the legitimacy of the whole $\mathrm{CC}$.

3. The ASOP team ensure there is a mechanism for public complaints about CCs (and other activities associated with government). Equally important, they ensure there is a mechanism for complaints to be investigated and solutions proposed and actioned. Identify whether the Gereshk example of a 'Complaints box' is working - and what lessons can be learned from this for other districts. 
4. The ASOP Planning team give much greater emphasis to making JSCs/CCs accessible to women disputants. The ASOP Planning team needs to be closely involved in programmes recommended under objectives 2 and 3 below.

5. The decision to have a woman District Justice Adviser in the PRT whose brief will include leading on gender and community based dispute resolution is welcomed. The following two recommendations relate to the functioning and composition of District Stabilisation teams and are intended to help capitalise on, and extend the value of, the PRT post.

6. Recruit woman to be Stabilisation Advisers and take steps to ensure that every Forward Operating Base (FOB) has at least one woman interpreter. There are currently no women in the District Stabilisation Teams. Without any women in FOBs there will be no-one to support the recommendations in this report that concern women's justice because men will not be able to communicate with rural Helmandi women;

7. Bring Stabilisation Advisers together regularly to meet and exchange ideas and experience (currently they rarely meet). Their knowledge of political and tribal relationships at district level is important in answering the 'yes but will it work?' question that needs to be asked of all new programming, including recommendations contained in this report.

With regard to PRSs, we recommend:

8. Replicate the Prisoner Review Shuras in newly-cleared areas, pending the establishment and effective functioning of a Prosecutor in those districts. The positive outcomes of PRSs in districts (prevention of unlawful detentions and unlawful releases; increased transparency and communication between Security Chiefs) need to be realised in newly cleared and held districts. Transparent processes are also needed in Lashkar Gah - this is the responsibility of the Chief Prosecutor.

\section{Ensure improved record keeping and mentoring of existing PRSs.}

\subsection{2}

Objective 2: Increase the Access of Women and Children to Justice

Changing attitudes around women and children - even to the extent of convincing men that women and children have individual rights that are separate to those of the family/lineage/tribe - will inevitably take a long time in Helmand. No one activity will improve this situation - a number of initiatives need to be tried; some will succeed even if others fail.

On the supply side, we recommend that the PRT work with Afghan partners to:

1. Influence other district CCs to adopt Gereshk's example in ensuring that women are elected to JSCs, and their successor institutions - District Councils. For example, have JSC members from Gereshk plus the DG visit CCs in other districts and talk about their positive experience of the Women's Shura. At the same time have the Women's Shura members visit other districts to talk to women about how their shura operates and the sort of issues women bring to them (to stimulate demand).

We hear from the PRT ASOP team that there was no appetite for a women's shura from men in other districts; nonetheless, it is worth another try.

2. If there is still no enthusiasm for a women's shura from male CC members then consider supporting the creation of independent Women's Shuras in each district. Ask the leading figures in the Gereshk Women's Shura members to advise on how to go about this - given that their shura was set up in Gereshk before the CC. Those organisations with already established networks at village level, e.g. ICWRC members, women teachers and health workers should also be consulted. ${ }^{11}$ Even if new Women's Shuras did not subsequently become integrated into the CCs, they might be useful platforms for women to stand as DC members in future. The PRT Rule of Law and Governance sections need to make it a priority to push for women's involvement in future District Councils.

\footnotetext{
${ }^{11}$ Many professional women - teachers and health workers - who work in LKG have family links back to villages. 
3. Identify a strategy to ensure that women's representation is included in any publicity surrounding the Sub-National Governance Policy - and the new law. The SNG Policy states that $25 \%$ of District Council seats will be reserved for women. On this basis, it is important that male elected bodies support their election. Despite this seemingly strong statement, the SNG policy is weak on women's representation as it says that the $25 \%$ of seats reserved for women will go to men "to the extent women are not available to contest these positions" - a let out clause. ${ }^{12}$ However, it is very important that the SNG policy intention to move towards women's representation on district councils is widely publicised.

On the demand side:

4. Extend the ICWRC network of women intermediaries that are currently working in LKG to women who are able to also contact women in villages. They might work from, or be linked to, places that women visit - clinics for example. The intermediaries themselves could be drawn from ICWRC and Department of Women's Affairs (DoWA) networks; they might also include teachers working in LKG but hailing from villages.

5. Train this group as paralegals - building on the training already received by 15 of the ICWRC group in Kabul in 2009. These women intermediaries would then need to develop a practical strategy through which they could reach and support women at village level.

6. Consider supporting a non-government Afghan community radio station to publicise women and children's rights. Such an initiative should be civil society led (i.e. separate from and additional to, a media-communications strategy that may be launched by the PRT and/or through government media). It is important that women and children's rights do not become associated only with government and foreigners but are also championed by local Helmandis. Such a programme might draw in respected religious figures, members of the Helmand Ulema and, depending on the district, Sayyids. ${ }^{13}$

In addition to recommendations around the justice sector, we also recommend:

7. A wider programme of civil society support for women in Helmand. If the aim is to help empower women in Helmand more generally then this needs a separate programme of support to civil society with this as its principal aim. As noted, the problems women face in getting justice are not just the result of the difficulty they have in accessing and being heard in both community-based and statutory justice systems. It is also, as women respondents said, 'the attitudes of our men'. The customary practices they complained about included multiple marriages, the unequal treatment of cowives, the marriage of very young girls to old men, being forced to ask for one's share of inheritance, and the abduction of young boys for sex with men. Support to organisations working on one or more of these issues would help address the wider issues of discriminatory practice highlighted by respondents in this study.

\subsubsection{Objective 3: Increase Awareness around Human Rights}

The Afghan Constitution reflects many standards that are enshrined in international human rights law. At the same time, Afghanistan is a State Party to many international human rights instruments. ${ }^{14}$ Hence, as noted earlier, a major issue going forward is how to increase awareness of human rights, particularly amongst current and future mediators in rural Helmand but also amongst members of the statutory justice system. This needs to be done in a consistent way rather than through a succession of individual training events, as has been the practice in the past.

We therefore recommend:

\footnotetext{
12 Section on 'Sub-National Elections' in the Sub-National Governance Policy, Islamic Republic of Afghanistan, September

${ }_{11}^{2009}$ CPAU is involved in a rights-based community radio initiative in Helmand and can be contacted directly for details.

${ }^{14}$ These include the Convention on the Elimination of All Forms of Discrimination Against Women (CEDAW) and the International Covenant on Civil and Political Rights (ICCPR). 
1. The UK supports the development of a comprehensive and coherent programme of training and related activities around human rights. Such a programme should include components suitable for community based dispute resolution mediators and components for statutory justice actors (with some mixing of participants in all training/discussion events). Such a programme is likely to involve a number of organisations and both state and non-state actors, depending on their mandates and capacity - a positive thing. However, rather than everyone doing their own thing, which appears to be what has happened to date, the programme should aim for consistency around:

- main human rights messages

- main themes (to include a focus on women's rights and, separately, children's rights)

- how Shari'a, Afghan law and international human rights standards are to be used in the adjudication of cases. Practical examples of both civil and criminal cases, will need to be given to illustrate how to ensure judgements are consistent with all three legal codes.

- who might deliver training and main messages to different group of participants

- who the participants should be (provincial, district, village), and

- how results - in the sense of changed attitudes and practice - are to be measured.

In other words, what is needed is a comprehensive programme of practical education around human rights that is working to a 'core curriculum and approach' which has been developed and agreed by all those involved - but that may be rolled out at provincial, district and village level in different ways and with the help of different combinations of organisations. Agreeing a consistent approach to the above points will aid quality control and should help identify impact.

2. We recommend that such a programme begins with a series of UK supported workshops that would draw together the representative of potential participant organisations to:

- map their interests, mandates, capacity and expertise,

- begin a discussion around overall messages and main themes,

- identify a Working Group that would guide programme development and implementation.

(Note: The PRT is currently facilitating JSSP to carry our training to strengthen capacities in the criminal justice system - this is about to be conducted in LKG and then rolled out to three Helmand districts. It would be helpful to know what its central messages around human rights are, how the course addresses women's and children's rights, and whether there are lessons coming out of the JSSP course that can subsequently inform discussions around such a programme.)

Objective 4: Improve the Links, Accountability and Oversight between the Statutory System and Community Dispute Resolution Mechanisms

This section is addressed to the Core Working Group responsible for developing the 'Draft National Policy on Relations between the Formal Justice System and Dispute Resolution Councils'. The Working Group works under the auspices of the MoJ and includes UK and US justice advisers.

The findings of this study are relevant to the draft national policy in several ways.

1. Recognition of community-based mechanisms. The fact that the draft policy fully acknowledges the role and usefulness of community based dispute mechanisms is positive - in Helmand, these are indeed the most trusted mechanisms for dispute resolution throughout the province, and the first port of call for almost all disputes, including in Taliban controlled areas.

2. Registration. Mandatory registration of all cases resolved through community-based mechanisms with 'a related government authority' is both impractical and unnecessary. Travelling to the district centre to register every small case from outlying villages would be dangerous (due to the security situation) and time-consuming. Moreover, it is unlikely that villagers would see a need if the Elders and/or Mullah had resolved the case to the satisfaction of both parties. However, for larger cases the right of one or both parties to voluntarily register the case might be very useful as a basis for the enforcement of the decisions of Elders and Mullahs in the state system, as well as helping 
prevent dissatisfied disputants shopping around for a decision that is more favourable to them. In other words registration could help to enforce and back the decisions made by Elders - a demand of many respondents in this study. For registration to work in practice, it would need to: a) be the voluntary decision of one or both parties; b) take place after a judgement had been made and both parties had signed saying they would abide by its terms; c) involve a speedy and free process; and d) involve no demand for informal payments.

3. Validation. The same argument applies here as to registration: requiring decisions made by Elders and Mullahs to be vetted by the statutory system and then validated is impractical and unnecessary. That said, preventing the abuse of human rights in community-based decision-making is very important. The issue is how to encourage communities (including, but not only elders and mullahs) to appreciate that giving girls in bad is against Islam and that alternative reconciliation processes exist and are used elsewhere. A combination of processes are needed to achieve this change:

- Make bad illegal under Afghan law (so that the law is consistent with Shari'a and international human rights standards);

- implement a public education campaign accompanied by messages from respected Ulema so that Elders and Mullahs - and the public in general - know that bad is not allowed in Islam and that alternative means of dispute reconciliation must be used instead (typically the transfer of property or money). Communicating this message in terms of Islam and Shari'a will have significant resonance with villagers;

- implement a comprehensive programme of human rights training for community dispute mediators - of the type recommended in this report. As awareness increases amongst community mediators about bad we would expect Elders and Mullahs themselves to stop using girls and women to settle disputes - as is reportedly the case in other provinces, ${ }^{15}$

- instigate and communicate a clearly defined appeals procedure - in order to protect the rights of individuals there must be provision for any party to a decision made by a community based mechanism to refer the case to the statutory system (for example in cases where there are alleged irregularities such as fraud, duress, coercion, bribery, corruption or alleged contravention of Shari'a, Afghan law or international human rights standards).

4. Criminal Cases. The issue of whether the community based dispute resolution mechanisms should be allowed to hear criminal cases is being hotly debated by Afghan and international justice specialists. We report what mapping study respondents said about this issue so that their voices can be taken into account.

Respondents in villages were used to their Elders hearing criminal cases. These usually involved assault or accidental or purposive killings that occurred when civil disputes (over land for example) got out of hand and the parties fought to defend both their property and their honour. The initial dispute may be between individuals but it can quickly broaden out to include a large number of kinsmen.

Respondents did not see prison sentences as 'settling' disputes between two parties. Several respondents noted that imprisoning a man for an accidental killing - or even a purposive one - does not settle the dispute. There were cases of men being imprisoned for years, but the dispute immediately starting up again on their release because there had been no participatory reconciliation process. Nor does a prison sentence take account of the position of the man's wives, children and other dependents and how they are to support themselves during his absence. From the perspective of those interviewed for this study therefore, it was better to allow Elders and Mullahs to adjudicate

\footnotetext{
${ }^{15}$ Respondents in Deborah Smith's Nangahar study report that bad is decreasing (Smith 2009); she finds the same in Kandahar (personal communication, July 2010). The incidence of bad in the five districts covered by this study is discussed in Annex 1. A complicating factor is that whilst men said its incidence was decreasing in some districts (e.g. Gereshk) women respondents disagreed.
} 
cases involving killing when this occurred as a result of a dispute between two parties as it was more likely to stop the escalation of violence, reconcile the two sides, and allow the more guilty party to continue to support their dependents. We might also add - drawing on women's voices in particular that reconciliation should be achieved through an agreement on the amounts of money and property the guilty party should pay to the other; girls and women should never be used in lieu of a monetary payment.

The above observations do not pronounce on the mechanisms of how the issue of criminal cases should be dealt with in the new law. It is, however, clear that it would not appear practical, feasible or in accordance with community desires to try to prevent community mechanisms from dealing with criminal matters. Further, the examples from the study stress the importance to ordinary people of the new law taking account of issues of reconciliation and social protection - which punishment by incarceration does not - both for civil disputes with criminal components and for criminal cases with civil/compensatory components. Study findings indicate that when Elders and Mullahs resolve such cases there is a good chance of achieving long lasting peace.

\section{A NOTE ON INDICATORS AROUND JUSTICE FOR THE HELMAND INSTITUTION BUILDING PROGRAMME (HIBP)}

This study was tasked with helping to establish baselines for the HIBP logframe as they apply to community-based justice.

One way of categorising indicators that could be used to estimate progress on the increased access to fair justice (specifically dispute resolution) in Helmand is to divide them into:

- public perception indicators that measure degrees of trust and perceptions of fairness in different dispute resolution mechanisms;

- supply indicators that measure both the availability of dispute resolution mechanisms to previously excluded groups and changes in practice due to increased awareness of human rights by mediators;

- demand indicators that measure an increased expression of demand for dispute resolution services from groups not using them before.

\section{Public perception indicators}

The HIBP indicative logframe (1/12/2009) already contains provisional indicators based on public perceptions about state courts and community based mechanisms. These have been drawn from The Asia Foundation (TAF) 2008 national survey. However, the two graphs presented in section 3 from the mapping study indicate a very different picture for Helmand, particularly with regard to the state courts. The trust level for 'the government system' which includes state courts, is less than $5 \%$ according to the Helmand mapping study; this contrasts with the TAF national study where $52 \%$ of respondents thought the state courts were effective.

Can responses on perceptions of fairness collected by this study and represented by graphs with percentages in section 3 - be used as a baseline for Helmand? They can - but only in an indicative sense. Although the study achieved a good diversity of respondents, the security situation did not allow representative sampling. However, with that proviso, and until the security situation improves, these figures are as good as one is likely to get for perceptions on different dispute resolution mechanisms from women and men in rural Helmand. Annex 2 on methodology discusses how a more representative sample of respondents could be obtained when the insecurity situation improves. (See 'The Issue of Sampling' under 'Selecting Respondents'.)

Demand and supply indicators have not yet been developed but easily could be. They need to be able to capture trends that are attributable to UK support.

With this objective in mind, we recommend that consideration be given to using the following sorts of indicators in the HIBP logframe as it relates to justice: 


\begin{tabular}{|c|c|c|}
\hline Aim & Measurable Indicator & How Assessed \\
\hline $\begin{array}{l}\text { 1. Community-based dispute } \\
\text { resolution mechanisms and state } \\
\text { justice increasingly trusted and } \\
\text { seen as fair by Helmand population } \\
\text { - and preferred to Taliban justice }\end{array}$ & $\begin{array}{l}\text { i) Percentage of men and women } \\
\text { who say they trust/see as fair } \\
\text { dispute resolution by } \\
\text { community/state/Taliban }\end{array}$ & $\begin{array}{l}\text { Public perception percentages } \\
\text { given in this report. But note: } \\
\text { follow-up assessments would need } \\
\text { to be with an equivalent group } \\
\text { (rural Helmandis, } 50 \% \text { women etc.) }\end{array}$ \\
\hline $\begin{array}{l}\text { 2. JSC/CCs increase access to } \\
\text { justice by women }\end{array}$ & $\begin{array}{l}\text { i) No. women on CC, Women's } \\
\text { Shura (and, in future) District } \\
\text { Councils } \\
\text { ii) No. women acting/working as } \\
\text { support intermediaries and } \\
\text { contacting women } \\
\text { iii) No. women bringing their cases } \\
\text { to public bodies, e.g. the Women's } \\
\text { Shura, DG, CC, Huquqs, } \\
\text { Prosecutors }\end{array}$ & $\begin{array}{l}\text { Baseline data already exists for i) } \\
\text { and ii). WADAN and ICWRC could } \\
\text { establish a baseline for iii). } \\
\text { Subsequent monitoring by WADAN } \\
\text { and ICWRC }\end{array}$ \\
\hline $\begin{array}{l}\text { 3. JSC/CC members increase their } \\
\text { understanding of basic rights }\end{array}$ & $\begin{array}{l}\text { i) No. men attending human rights } \\
\text { education programme } \\
\text { ii) Increased knowledge and use of } \\
\text { human rights principles to } \\
\text { adjudicate disputes }\end{array}$ & $\begin{array}{l}\text { Before and after interviews with } \\
\text { selected elders participating in a } \\
\text { UK supported human rights } \\
\text { education programme }\end{array}$ \\
\hline $\begin{array}{l}\text { 4. Elders in communities stop } \\
\text { using women and girls to settle } \\
\text { disputes }\end{array}$ & $\begin{array}{l}\text { i) Proportion of Elders since human } \\
\text { rights education programme saying } \\
\text { they have not used bad in dispute } \\
\text { settlement for murder cases }\end{array}$ & $\begin{array}{l}\text { i) Survey of all CC members in } \\
\text { Helmand to establish baseline re. } \\
\text { bad } \\
\text { ii) Follow up survey with same } \\
\text { elders post human rights } \\
\text { programme }\end{array}$ \\
\hline
\end{tabular}




\section{INTRODUCTION}

\subsection{Background}

There are several ways in which disputes and crimes are resolved in Helmand. These are referred to in different ways but for the moment we can refer to them as community-based dispute resolution (which involves Elder and Mullahs resolving disputes in communities), the statutory system (meaning the courts and state justice personnel) and Taliban mechanisms (meaning mechanisms run by the Taliban in areas they control).

In Helmand, the focus of this study, the community-based system resolves the majority of disputes in both government and Taliban/militia controlled areas. At district level statutory justice actors (prosecutors, civil rights specialists and judges) are gradually reassuming their posts, after fleeing to the provincial capital around 2004 when fighting escalated. However, in the intervening period other actors have filled the justice void. These include District Governors and, in some districts, the Community Councils of the Afghan Social Outreach programme (ASOP). Both now act as dispute mediators and referral agents. Helmand is therefore an example of a province with, in effect, four groups of dispute resolution actors: Elders and Mullahs in villages (active and used throughout the whole province), a skeletal statutory system (still mainly based in Lashkar Gah but gaining a district presence), a group of 'government' actors which includes the District Governor and ASOP Community Councils, and in Taliban controlled areas, Taliban dispute resolute mechanisms.

None of these processes, separately or together, offer ordinary people in Afghanistan access to clean, fair, timely justice. There are weaknesses in all of them. Because access to fair justice is one of the principal demands of Afghanistan's population providers of fair justice garner popular support. To capitalise on this the justice dispensed in areas under government/international control must be experienced as impartial, bribe free and fair by all parties. Links between community-based mechanisms and the statutory system must also work effectively so it is not a case of citizens shopping around for the mechanism that they think will best suit their interests or which they know they can influence with a bribe - which is what happens now. Rather, there need to be clear pathways that link justice mechanisms so that anyone with a dispute - say over land, an unpaid debt, inheritance or even a killing - knows who they should first approach and to whom they might be referred if the case requires a higher level authority.

From a government and international perspective the justice dispensed needs to be in line with the laws of Afghanistan and international human rights standards. This is critical if Afghanistan's justice system is to have international as well as national credibility.

Currently we are a good distance from this goal; however, the situation is not wholly bleak. Elders and mullahs adjudicating cases at community level have lost some of their stature in the last 30 years of conflict but still retain considerable authority. They handle the vast majority of disputes, both civil and criminal throughout the province. Community-based dispute resolution has significant weaknesses - and this report details these - but it also has enormous strengths, not least the ability to restore equilibrium between the parties and stop the escalation of conflict. Also, as noted, statutory justice actors are slowly returning to district centres. Five of Helmand's 13 districts now have a prosecutor, one has a judge and two have a civil rights mediator (a Huquq) ${ }^{1}$. These individuals have few facilities at present (some not even accommodation) but this is rapidly improving. And those districts with temporary justice mechanisms - the five districts with Community Councils for example are hearing cases, not a lot (2-4 a month), but they are helping. The District Governors are playing an important role, although as we will see, their role as chief referral agents between community-based processes and statutory systems is not without problems from the point of view of local people. The fact that some DGs also take on the role of resolving disputes - rather than just referring them - also raises questions about jurisdictional roles and responsibilities.

\footnotetext{
${ }^{1}$ Huquqs are an Afghan institution with no direct western equivalent. They are state actors from the Huquq (Rights) Department of the Ministry of Justice mandated to mediate rights cases - over inheritance, land, disputes between family, neighbours etc. and to refer them to the courts if necessary. However, their level of activity in Helmand was difficult to gauge as none of the three huquqs currently in post (based in LKG, Gereshk and Nad-e Ali) were mentioned by respondents.
} 
Although there is progress there are also major challenges facing government and international partners supporting the justice sector. These can be captured in two questions:

- Community-based dispute resolution and statutory justice systems both have strengths but also major weaknesses; how to get rid of the weaknesses?

- How might community-based dispute resolution and the statutory system then link - so they give women, men and children access to clean and fair justice - but without a duplication of roles and resources?

\subsection{Aims of this Study}

This study aims to inform discussions around both the above questions by providing a bottom up perspective from Helmand. This is the first study to focus on how people resolve disputes in villages in rural Helmand, i.e. outside district centres. ${ }^{2}$ It asks women, men and young people of both sexes to describe how different justice mechanisms currently operate and how they link, what is working well and what is not, and what needs to change if they are going to get justice. This, together with findings from other data sources detailed below, enables an assessment of current GIRoA and international efforts to bolster both community-based mechanisms and the statutory justice system and to link them.

From a UK perspective the study fits into the ongoing Helmand Institution Building Programme (HIBP) as well as the Helmand Plan. The former aspires to the goal of a critical mass of the population accepting the legitimacy of Helmand's governing institutions and rejecting unlawful alternatives. Its purpose is to improve the capability, accountability and responsiveness of Helmand's governing institutions to deliver basic services, including justice. The HIBP complements the objectives of the Helmand Plan, which can be expressed in broad terms as effecting stabilisation at district level. This study is part of the inception phase of HIBP and expected to contribute to the justice output of the programme.

Specifically, the study was designed to:

- Map how men and women get disputes resolved in rural Helmand;

- Review the contribution of UK support to Prisoner Review Shuras (PRS) and to the justice work of Community Councils (CCs) supported under the Afghan Social Outreach Programme (ASOP);

- Provide recommendations to inform future action and programming in the justice sector.

Although the Terms of Reference for the study specify that the focus should be on the informal (community-based) system it is difficult to separate this out in practice, not least because cases go back and forth between different systems and also involve other actors - District Governors, the Community Councils, the police and security forces. The focus on the study is therefore on dispute resolution at village and district level; we did not follow cases through to the court system in Lashkar Gah and there is no discussion of what happens there. In retrospect this would have been helpful as we would then have a holistic picture of the whole process - from village Elder to the judge and courts in the provincial capital.

It was hoped that a review of the Helmand Provincial Reconstruction Team's (H-PRT) work with the statutory system would have been carried out at the same time as this study. This did not take place, although one is planned in the near future.

\footnotetext{
${ }^{2}$ Kate Fearon's work on dispute resolution in Helmand (June 2010) provides a district centre (rather than village) view of how dispute resolution works in the province and complements the information given in this study in many respects. Deborah Smith's work provides a village-based perspective on dispute resolution in two other provinces - Nangahar and Bamiyan (AREU, December 2009). 


\subsection{The Afghan Policy Context}

At the time of writing the Government of Afghanistan (GIRoA) is developing a new law on how to link community-based dispute resolution and the statutory justice system. There have been ongoing discussions between GIRoA and parts of the international community (the US, the UK, ISAF and parts of the UN) on how such links might work. In November 2009 a Core Working Group produced a 'Draft National Policy on Relations between the Formal Justice System and Dispute Resolution Councils'. This recognised the importance of community-based dispute resolution but held back on setting out how it would link with the statutory system. If the new law builds on the suggestions made in the draft policy it is likely to make provision for the statutory system to have an oversight and monitoring role vis-à-vis community-based mechanisms. 3 The idea of a 'formal' justice system regulating an 'informal' one is sound in principle. The practicality of how this might work in the light of study findings is one of the issues discussed in this report.

\subsection{Evidence Base and Methodology}

This report relies on four main sources of data:

- A 'mapping' - or information gathering - study. This involved individual interviews with 269 men and women drawn from 57 villages across five Helmand districts (Garamsir, Gereshk, Nad-e Ali, Nawa and Musa Qala). ${ }^{4}$ Just over half the respondents $(51 \%)$ were women. All respondents lived in villages/settlements outside the district centres, most in areas under government or semi-government control; ${ }^{5}$

- Interviews with national, provincial and district GIRoA officials (Ministry of Justice, the Afghan Independent Human Rights Commission (AlHRC), District Governors (DGs), District Chief of Police (DCOPs), District Chiefs of the Afghan National Army and National Directorate of Security (ANA, NDS), Prosecutors, the Department of Women's Affairs (DoWA), and Community Council members;

- Reports by, and interviews with, justice specialists focusing on policy debates and justice processes in Helmand and other Afghan provinces. This included DFID and Helmand PRT staff and consultants; the US State Department's Justice Sector Support Programme (JSSP); civil society actors including WADAN and the Independent Committee for Women and Children's Rights (ICWCR);

- The wider literature: including on justice in other Afghan provinces, Helmand agricultural surveys (to understand settlement patterns as a background to land and water disputes), and Helmand tribal and ethnic breakdown by district.

The methodology for the study had to take account of a challenging research environment. Roadside bombs and checkpoints - which can be manned by Afghan National Police (ANP) in the daytime but Taliban or narcotics militia at night - make all road travel a risk. Ad hoc and targeted bombings, including in the bazaar areas of towns under government control, are a frequent occurrence. The Taliban are known to keep a close eye on any organisation or individual seen to be collaborating with the government or foreign security forces; thus, the risk of the Taliban targeting those taking part in this study had to be factored in to study design.

\footnotetext{
${ }^{3}$ The Draft National Policy recommends that decisions made and agreed in the community-based system will be subject to 'validation' by a relevant government department so that any judgements seen to violate human rights or contravene Afghan law can be picked up and overturned.

${ }^{4}$ Early in the study we agreed with DFID to focus on Nawa district rather than Sangin, which is the district specified in the TOR. This was due to the tense security situation in Sangin at the time of fieldwork but also to the support of the then Nawa Stabilisation Adviser who was keen Nawa be included in the study and provided comprehensive details on Nawa's political, economic and social background.

5 The exception to this was Musa Qala where it was important to also get the experiences of respondents living in Taliban controlled areas given that the Taliban control much of the district. This was achieved through recruiting the district vaccinator as the male interviewer - the Taliban had given him 'safe passage' papers so that he could also work in areas they controlled. Annex 2 gives further details on how respondents were selected.
} 
An Afghan research organisation, Cooperation for Peace and Unity (CPAU) undertook the mapping exercise. They identified and trained local Helmandis to interview in villages where they felt safe to travel to (i.e. where they had family connections). Questions were mainly qualitative; they asked for descriptions of processes and actual examples of disputes and their outcomes. There is quantitative data on just one issue: the perceived fairness of different justice systems (responses are presented as graphs in section 3). The open-ended questions that were the core of discussions with each respondent are at annex 2 .

Study findings should be seen as illustrative rather than representative. The volatile security situation, the lack of a sampling frame and the short time available for field research (two months) did not permit representative sampling. That said, careful attention was paid to ensuring respondents were not biased towards any one group but were drawn from different age categories, diverse geographical locations and different occupational backgrounds. ${ }^{6}$ A summary of the key security and logistical difficulties, and the methodology developed to address these is at annex 2 . This annex may be of interest to other agencies or programmes undertaking field research in Helmand.

\subsection{Acknowledgments}

Many people contributed to this study - just two groups are mentioned here. First, our thanks go all those men and women who took part in the mapping study and interviews and to the Helmandi interviewing team who managed to interview equal numbers of men and women and record interviews verbatim, in an exacting field environment. Second, we are grateful to DFID and Helmand PRT justice and governance advisers for previous well-documented work and the support and advice they gave throughout the study period. This study builds on their analyses, insights and questions; this report has been revised following their comments.

\subsection{Organisation of Report}

This report has three main parts:

- Findings from the mapping study. There are two sections here: Section 2 focuses on the steps people take when they have a dispute, whether they live in an area controlled by GIRoA or the Taliban. Section 3 compares people's perceptions of the fairness of different systems and accounts for differences between them.

- Review of current support. Section 4 uses the findings of the mapping study and other interviews and documentation to review aspects of current UK support to the justice sector, focusing on the justice work of Community Councils and Prisoner Review Shura.

- Implications for current and future work. Section 5 looks at the implications for study findings for current and future approaches and programmes. It is organised in terms of a number of 'Frequently Asked Questions' - actual questions raised in the TOR or by colleagues in Helmand and Kabul during the study. Responses to these FAQs provide a useful way of linking the data with issues of concern to those involved in justice sector work.

Recommendations are made throughout the text and summarised in the Executive Summary.

The annexes should be consulted for specific information: on types of dispute and justice actors mentioned by respondents in different districts (annex 1); and on the methodology adopted and lessons learned from this (annex 2).

\footnotetext{
${ }^{6}$ Male informants included elders, mullahs, farmers, shopkeepers, traders, landowners, sharecroppers and daily wage labourers. Women were mostly household based, a very few (four out of 137) had paid employment as teachers or midwives. 


\section{DISPUTE RESOLUTION IN HELMAND: FINDINGS FROM THE MAPPING STUDY}

\subsection{Terminology}

Early in the research we realised that the terms 'informal' and 'formal' do not accurately describe justice processes in Helmand. The so-called 'informal' system, adjudicated by Elders and Mullahs, is quite formal: it is based on known principles, has a referral system, records judgements, and is bribe free. The so-called 'formal' system is, in contrast, a sea of informality with bribes a common feature at every stage of the process. We therefore looked for better descriptors.

Other reports use the term 'traditional dispute resolution mechanisms' or TDR to describe justice adjudicated by Elders and Mullahs. However, the term 'traditional' implies a system that is static and unchanging and, as demonstrated later, community-based dispute resolution, although based on the 'traditional' principles of Pashtunwali (or 'way of the Pashtuns'), is not one thing. The way it is applied can vary between and within districts as well as change over time. 'Traditional' justice is therefore not an accurate descriptor either.

After some consideration we decided on the following terms:

- Community-based dispute resolution mechanisms. This is used in place of 'the informal system' to describe dispute resolution by Elders and Mullahs. As noted, community based mechanisms currently deal with the vast majority of disputes, both civil and criminal in Helmand. ${ }^{7}$

- The Statutory system. This is used in place of 'the formal system' to refer to state justice institutions and personnel - the courts, judges, prosecutors, defence lawyers, and civil rights mediators (Huquqs). At the time of writing the statutory system normally meant 'the court in Lashkar Gah', although as noted, Prosecutors and Huquqs are now present in some districts.

- Taliban dispute resolution mechanisms. This term is used to refer to justice dispensed by the Taliban in areas they control. This either involves mobile courts (uttaq) or Taliban Commanders identifying Mullahs and Elders to hear cases for them and report back on judgements made. There is a two-tier referral system for unresolved cases.

It is important to note that Helmandi respondents used slightly different terminology and categorisations to those above. For example, they called dispute resolution by Elders and Mullahs 'the People's system' (Wolisi) rather than the 'Community-based' system. And the majority did not use the term 'statutory' or even 'state' justice. Rather, they bundled all government law and order personnel together and referred to them as the Government system. This included the District Governor (DG) and District Administration (DA), the Records Office (Amlak), the police, army and security/intelligence services (ANP, ANA and NDS), and statutory actors (prosecutors, judges, courts etc.). Few, if any, respondents had a concept of an independent judiciary. We use the term Government system when reporting the views of informants referring to this broad category of actors.

Interestingly, most respondents also categorised the Justice Sub-Committees (JSP) of the ASOP Community Councils as being part of the Government system. This was because, in their capacity as $\mathrm{CC}$ members, they were seen as paid government employees who worked alongside the District Governor.

\footnotetext{
${ }^{7}$ In donor documents it is often said that the community-based system handles anything from 85 - $99 \%$ of justice cases in Helmand, implying that the remainder (1\%-15\%) are handled by the statutory system. Although the use of percentages sends a strong message, and one that is correct ('community based dispute resolution handles the vast majority of disputes in Helmand') the data is not available to express this in percentage terms. 


\subsection{Dispute Resolution: (i) in Government Controlled Areas}

Every respondent in the mapping study was asked to describe what happened when an individual, household, sub-lineage or larger group had a dispute with another party. Although there appeared to be differences between and within districts in terms of the types and seriousness of disputes, the process was broadly similar across all five districts. ${ }^{8}$ Women in Helmand are rarely allowed to take a dispute out of the household as this implies that the male members of their family are unable to control them - an honour issue. What women do when they have a dispute is discussed separately below.

\section{Steps in Dispute Resolution}

The steps identified through the mapping study broadly reflects the steps identified in previous justice reports by DFID and Helmand PRT staff as well as reports on justice processes in other provinces. ${ }^{9}$ All male respondents, wherever they lived, turned first to people they knew (local Elders and/or Mullahs) when they had a dispute. The principle of subsidiarity was strong, i.e. the desire to resolve disputes at the lowest and most local level possible. In practice this meant a step-by-step process of justice resolution where parties would only move 'up' to the next level if no agreement were reached at a lower one.

The steps outlined below apply to all civil disputes, for example, over land and property boundaries, water sharing, unpaid debts, inheritance, divorce, marriage, children fighting etc. They also apply to disputes that turn violent in the course of events and therefore may include criminal acts (such as killings).

Step 1. Disputants will first try to resolve an argument themselves in order to keep it private. Making a dispute public is avoided if possible - for honour reasons. However, if the parties cannot agree then...

Step 2. They consult their local Elders and Mullahs. They will interview witnesses and collect other evidence (e.g. land records). The disputants may appoint representatives (wakil) to deal with the case in the one or more jirgas (meetings) that are held to review evidence and resolve the conflict. If the Elders negotiate a resolution acceptable to both parties, then the case is recorded and the two parties sign their acceptance of the judgement and its conditions. However, if one side will not accept the solution offered then...

Step 3. At this point the disputants might go directly to the government or to the Taliban, depending on who has control in their area. But they may also decide to stay within the community and seek the mediation of higher-level authorities. This is particularly the case when the dispute is between larger groups - lineages, sub-tribes or tribes. Respected Tribal Leaders, Maliks or Sayyids will be asked to come and mediate/adjudicate. ${ }^{10}$ They are more likely to settle a big case than local Elders because of their high status - the parties will feel honour bound to accept the solution they offer. Many respondents noted that although the authority of such individuals has declined over the last 30 years they still have significant sway; particularly in some districts (for example, Sayyids are highly respected in Garamsir).

\footnotetext{
${ }^{8}$ More information about the districts covered in this study is at annex 1 . This includes a note on apparent differences in types of dispute, which normally have to do with population settlement patterns, position on the canal (head/tail), relations between Kuchis and settled populations, tribal heterogeneity and so on.

${ }^{9}$ See for example, reports by Fraser Hirst and Kate Fearon with regard to Helmand and Deborah Smith's analysis of justice dispute resolution processes in Nangarhar and Bamiyan, AREU, 2009.

${ }^{10}$ The higher level authorities mentioned differed by district - and even within districts. Thus in Garamsir many respondents said they turned to their Sayyids (respected spiritual leaders) as second level referral authorities; in Gereshk they turned to Maliks (respected Elders - originally the person with authority to enlist young men for the army, collect taxes and represent the community to the state). Tribal leaders would be contacted if the dispute involved major disputes between lineages or tribes.
} 
It is worth noting at this point that there are two sets of principles used to adjudicate disputes in community-based dispute resolution in addition to local and tribal practice/precedence. Elders and Tribal Leaders use Pashtunwali principles where the aim is to preserve group honour and to reconcile conflicting parties. Mullahs - if they are knowledgeable about Islamic law - use Shari'a where the aim is to give individuals their rights under Islam. ${ }^{11}$ Thus, the jirgas held to work out a settlement can involve lengthy debates between those adjudicating a case as these two principles of dispute resolution often conflict. ${ }^{12}$ Shari'a is based on a concept of individual rights; Pashtunwali focuses on the need for community reconciliation through the re-establishment of equilibrium and the maintenance of group honour.
"Some people go directly to their local Mullah not to their Elders and some go to Elders first and then the Mullah. The Mullah's advantage is that they have knowledge of Shari'a and can use this to guide each case. However, if you don't want your case to be judged by Shari'a and you think you'll be better off with Pashtunwali then you go to Elders." (Male respondent, Nawa)

However, the presence of a Mullah in a dispute reconciliation jirga does not guarantee a decision based on Shari'a. Local mullahs in Helmand tend to have only a very basic religious education; they can recite some shuras of the Qur'an but are not, by any means, theological scholars (ulema). Because they also tend to be poor and may be beholden for their livelihood to local landlords or Khans the presence of a Mullah in dispute resolution jirgas is primarily for legitimacy purposes. ${ }^{13}$ Respondents gave no examples of a Mullah challenging judgements based on Pashtunwali - even though Pashtunwali based judgements can conflict with Shari'a.

The focus on reconciliation in Pashtunwali, and not on individual rights, can have profound implications for girls and women. In serious disputes involving large debts or killings the Elders will decide on an amount of money, land or other property that the guilty party needs to transfer to the other side. However, if the guilty party is very poor, or if the Elders feel no amount of property will stop the cycle of violence and bring peace, they may decide that an unmarried girl should be given to help seal the reconciliation deal. This practice, known as bad is one of several ways in which girls and women are used to help settle disputes in Helmand. Although respondents indicated its use is now rare in some districts (Garamsir) they reported it remains common in others (Musa Qala). Bad is both a financial transaction (bad marriages incur no brideprice so the receiving party makes a considerable saving) and a social one (the expectation is that renewed conflict is less likely if the parties have a kinship relationship). Women and men's attitudes to bad and other practices are discussed in section 3.

Step 4. If community based mediators are unable to resolve the case then it will be taken to 'the Government'. In Helmand districts this normally means the District Governor (DG) as he is the entry point to the statutory justice system. ${ }^{14}$ This may change as Prosecutors and Huquqs become more visible and active in district centres but at the time of the study these personnel appeared little known, and were not mentioned by respondents.

\footnotetext{
${ }^{11}$ Other factors also inform decisions made by Elders and Mullahs. They will consult land records, witnesses, etc., and consider other relevant factors (e.g. the history of disputes between the parties, economic, tribal or other identity issues relevant to the dispute, whether a killing has left women and children without economic and social protection etc.). They will use all of this information in making a judgement and proposing terms for reconciliation.

${ }^{12}$ Barfield et al make the same point - that Shari'a and Pashtunwali are not the same - yet are often conflated. This conflation fits the view, often held by urban elites and non-Afghan specialists, that because the Afghan population has a reputation for adherence to Islam that customary and religious law must be one and the same. Barfield, T, N Nojumi and J. A. Thier 'The Clash of Two Goods" US Institute of Peace, 2006

${ }^{13}$ This was also a finding in the study by CPAU on religious society. See 'The Role and Functions of Religious Civil Society in Afghanistan: Case Studies from Sayedebad and Kunduz', Cooperation for Peace and Unity 2007

${ }^{14}$ The exception to this is if there has already been an arrest or if the police are a part of the dispute; in this case the District Chief of Police will be the first port of call.
} 
The DG may solve the case himself or he may refer it. Criminal cases will be referred to the Prosecutor where evidence will be prepared for the court in LKG. In districts with a Community Council (a group of elected Elders supported under the Afghan Social Outreach Programme) small scale civil cases will be referred here. Community Councils (CCs) hear two sorts of cases - rural cases that have not be solved earlier and 'first appearance' cases bought directly to the CC by district centre residents. ${ }^{15}$ This means the CCs should be seen as both step 4 and Step 2 of the process. We found no evidence of CCs hearing cases where a civil dispute (e.g. over land) had escalated into violence and involved a murder. If CCs do hear murder cases there was no evidence from this from the selection of records obtained for us by WADAN from Justice Sub-Committee Chairmen. ${ }^{16}$

Step 5. The final stage in dispute resolution for both criminal cases and for serious and unresolved civil cases is the statutory system. If the district has a Prosecutor he will collect the evidence and then send the case to the court in Lashkar Gah. However, as noted, disputants will try and stay out of the court system if they can. This is due to its known weaknesses (bribery, time consuming procedures) but it is also because a court hearing is not necessarily seen as the best way of resolving a civil dispute, even if it has become criminal (e.g. because a killing has occurred). The family of a dead man reaps no practical benefit from his adversary going to jail. Nor will this necessarily resolve the dispute. Indeed hostility may linger until he comes out, at which time conflicts can start up again. A reconciliation payment - or a daughter handed over as bad - is therefore seen as more beneficial for both sides than the 'punishment' of the guilty party through a custodial sentence. As we will see, this is not necessarily a view shared by women - or, indeed, all men, some of whom said that bad can exacerbate enmity between parties. This happens particularly if the girl given in bad is unkindly treated by the family she marries into. Because she represents the 'enemy' camp discriminatory treatment by in-laws, including other wives, can and does occur. Women respondents in the mapping study gave many examples of cruel treatment to girls given as bad (particularly until she bears sons) and some men also commented on this.

The absolute authority of senior men in such transactions must be noted; women and girls have no influence, but neither do boys and young $m$

\subsection{Dispute Resolution (ii) in Taliban Controlled Areas}

As noted previously, everyone with a dispute will first go to local Elders and Mullahs; this is also true for those living in areas under Taliban control.

If local Elders cannot settle the issue then disputants will go to the nearest Taliban Commander. Men feel they have little choice in this matter; it is too dangerous for them to try and get the case heard by the government/state system. As respondents noted, the Taliban use the justice system to exercise control and they don't take kindly to 'their' residents trying to use state justice. Since the Taliban have spies in all the district centres word can get back if parties try to do this.

The local Taliban Commander will either resolve the case himself or designate pro-Taliban Mullahs and Elders to hear it on his behalf. Alternatively, if the district has a mobile court (uttaq) he will ask the court to travel to the village where the dispute is going on and hear the case there. All written judgements will be passed back to him so he can ensure agreements reached are adhered to, by force if necessary.

If one party disputes the judgement then there are two further referral steps. The first is to the Justice Committee of the Taliban District Commission (equivalent to the District Administration on the government side). This Committee will settle most unresolved cases. However, we heard of one long

\footnotetext{
${ }^{15}$ It is clear from an examination of records of CC meetings held by JSC chairman that many cases come directly from bazaar residents. (A sample of cases from four districts was obtained through WADAN and translated from Pashto) Many of these involved minor disputes of an urban character, e.g. about rights of way between houses and disputes between shopkeepers. We are grateful to WADAN, the NGO supporting the ASOP programme, for obtaining a selection of records for us.

${ }^{16}$ There was not one criminal case dealt with in the records we obtained and translated - although it must be emphasised that the records we managed to get hold of were not complete.
} 
running case involving a large area of land that had been referred to the very final Taliban court of appeal: the Quetta Shura. It was still being negotiated.

Although the above account makes it sound as though the Taliban run a completely separate dispute resolution system to those in place in government-controlled areas, there are links in practice.

Respondents gave several examples of the Taliban allowing individuals resident in 'their' areas to go to the Records Office (Amlak) $)^{17}$ in order to check on ownership and boundaries. ${ }^{18}$ More complicated arrangements have to be made when one disputant lives in a Taliban controlled area and the other in an area under GIRoA jurisdiction.

\begin{abstract}
"If one (party to a dispute) lives in a Taliban area and one in a government area then it is up to the person in the government controlled area as to whether he is willing to come to Taliban area to resolve the case. If not then the party who is living in the Taliban controlled area must get permission from the Taliban to go to a Government court. If they allow this then the person must give a relative as a guarantor to stay with the Taliban whilst the man is away.... When he is in the district centre the Taliban intelligence will testify as to whether the person has really gone for a dispute or not."
\end{abstract}

One further point is worth mentioning. Taliban justice is based on Shari'a not Pashtunwali. However, the Taliban's Shari'a is not one that people in rural Helmand necessarily feel familiar with and claim as their own. Elders in one district referred to them as 'Wahhabi' to distinguish the Taliban's interpretation of religious law from their own Hanafi legal system. This association of the Taliban with a form of Shari'a that is unfamiliar and includes harsh punishments significantly affects people's responses to them - as is clear from findings presented in the next section.

\title{
3.4 What Happens When Women Have a Dispute/Problem?
}

The mapping study recorded scores of disputes mentioned by women. These mainly had to do with domestic and family matters - domestic violence, mental abuse, forced marriage of girls and women to settle a dispute or to pay off a debt, forced claims for inheritance, the custody of children, and discrimination against first wives. This concentration on family matters by women respondents is the result of women's lives being so privatised and their movement being so restricted; there are few opportunities for disputes with outsiders as they rarely meet them. Disputes around property with neighbours or kinsmen affect women as household members but men deal with these - women are never called upon to take part in jirga meetings to resolve them. If women have to be involved because the dispute is over divorce or inheritance for example - a male representative (wakil) will be appointed to represent them.

Even when there is a dispute with another family member the vast majority of women interviewed said they do not have the authority to bring their complaints to anyone outside the household; they must settle them internally by appealing to mothers-in-law and other senior women - and sometimes by going to fathers-in-law - or they must suffer in silence. Appeals to their parents may not help; it is against Pashtunwali notions of honour for parents to intervene in the affairs of a married daughter's household. This is extremely problematic as it is normally husbands, in-laws and co-wives that women have disputes with. Respondents gave many examples of violent incidents that women of the household had been told to keep quiet about, including honour killings hushed up or passed off as accidental deaths.

However, in a small number of circumstances girls and women do make their disputes public. One positive example comes from Gereshk district where five women have been elected to the Community

\footnotetext{
${ }^{17}$ The importance of the Amlak for land records depends on the district. In Nad-e Ali and other areas where there have been recent settlement on government irrigated land the settlers all had their plots registered and their records lodged with the Amlak in the 1960s and 70s. In areas untouched by irrigation schemes (e.g. Musa Qala, southern Garamsir) land owners tend to keep their land records at home.

${ }^{18}$ There was even a case (in Gereshk) of a Taliban Commander granting safe passage to Amlak officials to visit the Taliban controlled area and clear up a dispute between two individuals, one of whom was a policeman. The idea of the Taliban offering safe passage to government officers and a member of the ANP went down well with villagers who suggested it showed how much the Taliban's word could be trusted, a quality they found wanting on the government side.
} 
Council; two of them are on the Justice Sub-Committee. The 'Women's Shura' (as they are known) have helped a number of women bring their cases to the CC and have them resolved. This shows that if women intermediaries are available then women can and will bring their problems to public dispute resolution bodies. It is important that such intermediary women are seen as legitimate by men in the community, otherwise they will not be taken seriously, or will be defamed (called prostitutes etc.). The five Gereshk women have been publically elected as CC members so have the authority of government behind them. Unfortunately no other district looks like following Gereshk's lead; there is reportedly no appetite for women members amongst the other four all-male Community Councils. However, this could be also partly due to the ASOP team, which supports the CCs, not yet making women and children's rights a priority.

Widows sometimes also appeal to outside bodies. Unless widows are immediately married off to their husband's brother or another male relative (as is the custom under Pashtunwali) they can be left without anyone to provide food for themselves or their children when their husband dies. Their widowed status - but also their desperate situation - makes them more likely than other women to seek outside help.

The final category of women who try to seek help independently are runaways. Generally these are girls between 9 and 14 who are either to be given as bad or are to be married to older men in exchange for a much enhanced brideprice payment. ${ }^{19} \mathrm{~A}$ number of young girls are so fearful of such unions that they run away. Respondents said that if caught by their families they would normally be killed. Even if they find help, for example if they are picked up at an ANP checkpoint and sent to the women police officers in Lashkar Gah, they are very vulnerable. ${ }^{20}$ They will not become the subject of a formal dispute resolution process as their family will want to keep the event as private as possible. But because there is nowhere in LKG to keep them safe they are inevitably handed back to their families, or, if this is deemed high risk, placed in custody. The best that can then happen is that their families decide to delay the marriage for some time. There is no chance of parents changing their minds to agreeing to marry their daughter to a man of her own age; once betrothed she is counted as her future husbands' property. As noted, neither girls nor boys have any say in the choice of marriage partners.

Of these three groups of girls and women who manage to take their disputes out of the household only the first example - women seeking the help of the Women's Shura members in Gereshk - is positive. The others are seeking help not because it is accessible - it isn't - but out of desperation.

We have focused on girls and women in this section but young boys (12-18) also have little recourse to support or protection if abused. Respondents gave many examples of boys being kidnapped and used for sex with men, including by the police and other government officials. Although homosexuality is shunned in Helmand and treated as a crime against Islam this attitude does not extend to men having sex with boys. Indeed, for the district chief of a security force to have good-looking young boys in his entourage appears to be seen as both normal, and status enhancing. Again there is no form of independent protection for such boys.

\subsection{Summary}

1 Community-based dispute resolution (Elders and Mullahs) is functioning across rural and urban Helmand and is the first port of call for all disputants, including in Taliban controlled areas.

\footnotetext{
${ }^{19}$ A man of 55 or 60 marrying for the third and fourth time in Helmand, and wanting a very young bride, must pay about four times the amount of brideprice to the parents of the girl than for a first marriage to a bride of his own age.

${ }^{20}$ Two runaway young girls (of 12 and 14) were being looked after by some ANP women police officers in LKG when we visited in April 2010. They were about to be taken to hospital for a medical check to see if they had been raped prior to or at the ANP checkpoint (where they had gone for help). The women police officers were in touch with the Department of Women's Affairs about mediating with their parents. There is no refuge for women or girls in LKG yet although the PRT plans to build one. In the meantime women police officers and DoWA have a valuable role in assuring such girls have temporary protection. Currently however, there is nowhere for them to go except back to their families - who are likely to marry them off immediately to salvage family honour.
} 
2 In principle dispute resolution mechanisms are hierarchically linked. Community-based Elders and Mullahs are approached first and resolve the majority of cases. District Governors - and Taliban Commanders in Taliban controlled areas - then function as the gateways into their respective systems.

3 Statutory justice actors (prosecutors and huquqs) are only gradually reassuming their roles in districts. In the meantime other actors have a justice role at district level - the District Governors play a major part in justice and the Community Councils resolve civil disputes in the districts in which they operate.

$4 \quad$ There have always been links between the different dispute resolution mechanisms. Although normally sequenced - disputants go to community-based mediators first, and then the statutory system - cases can go back and forth between them.

Currently, there is no one set of agreed principles or laws used in dispute resolution:

- Judgements in the community-based dispute resolution rely on Pashtunwali and Shari'a and on local or tribal practice/precedence. Pashtunwali and Shari'a can conflict. Pashtunwali aims to reconcile conflicting parties; Shari'a aims to give individuals their rights under Islam. In Helmand Pashtunwali normally dominates as rural mullahs are not sufficiently versed in Shari'a to influence decisions. The exception to this is in Taliban controlled areas where Taliban versions of Shari'a are applied.

- Judgements in the statutory system rely on the numerous and sometimes conflicting laws and decrees passed over the last 50 years.

$6 \quad$ Women in Helmand are not allowed (by male family members) to initiate cases and most women do not dare take their problems to anyone outside the household. In effect this means the vast majority of women have no access to dispute resolution mechanisms in Helmand.

7 The Gereshk 'Women's Shura' is an example of the type of support women need to make their cases public. But currently a women's shura exists in only one district and its reach is currently limited to women in the bazaar area. An Afghan organisation supported by the PRT - the Independent Commission for Women and Children's Rights (ICWRC) - is currently undertaking a study to identify the problems women have in Lashkar Gah and the sort of justice support they want. They are keen to extend this work - and the paralegal support they can provide - to women in Helmand's districts and villages in future. 
This section reports on findings to a question asked of all mapping study respondents: 'Do you trust $X$ system and think it is fair?' 'Why or why not?' Respondents were asked for their views on the fairness of dispute resolution mechanisms in the three systems they identified: the People's system (Wolisi, i.e. Elders and Mullahs), the government system (a conflated category comprising government and statutory justice actors) and the Taliban. Responses have been disaggregated by the sex of respondent. $^{21}$

\subsection{Perceptions of Fairness (i) Community Based Dispute Resolution}

\section{Male Respondents}

As the graph below demonstrates the majority of male respondents said they completely trust community-based dispute resolution; they referred to this as the People's system (Wolisi). This was expected as it was in line with findings from other research. What is interesting however, is that the community system did not have $100 \%$ support from men; over a third of male respondents said they had only partial trust in it, or no trust it at all.

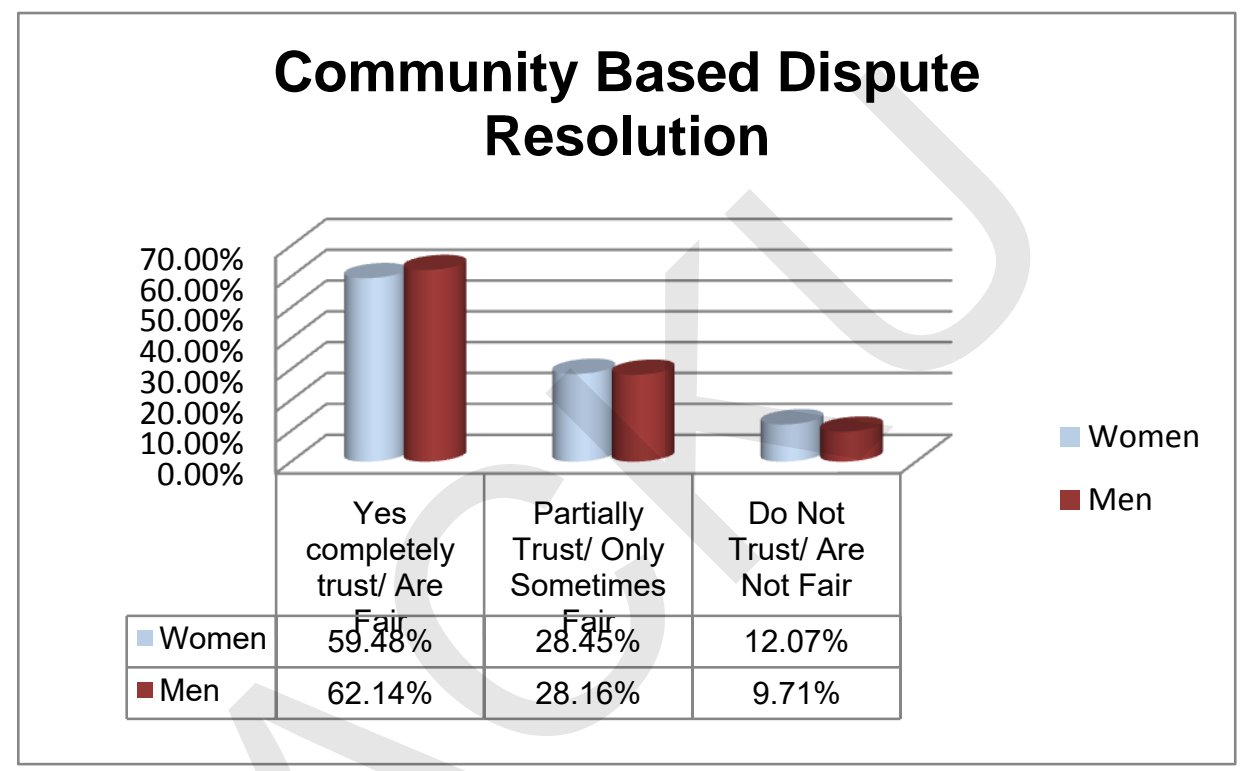

Follow-up discussions indicated that the major drawback with community-based dispute resolution is that the decisions of Elders "cannot be enforced". This may reflect on the authority and status of Elders themselves, i.e. that nowadays they have neither the military might nor the moral authority to make sure their judgements stick. ${ }^{22}$ But it may also say something about changes within communities since the Elders system is wholly dependent on the moral weight of the community ensuring disputants keep to the agreements they sign up to. Hence, whilst the authority of Elders has ebbed and waned over time, the last 30 years of on and off conflict have also undermined the cohesiveness of communities so that their moral force is less now than in the past. In practice - and as respondents were quick to point out - this means that 'opportunist' disputants can agree to the Elders' decision one day but then re-open the case a few months later by going straight to the District Governor and asking him to hear it, pleading a change in circumstance or new evidence.

\footnotetext{
${ }^{21}$ Responses were also disaggregated by district but there is not enough difference in district responses, and in any case numbers are too small, to warrant separate graphs.

${ }^{22}$ This compares to the mujahadin and Taliban times when mujahadin commanders and then the Taliban administration were approached to resolve disputes; both had militia that ensured decisions stuck. Older respondents who could remember the Daoud and Soviet years also remembered decisions sticking because they were backed by the state. Today it seems to depend who you get: some tribal leaders continue to have a militia at their disposal whilst some spiritual leaders have very high levels of moral authority - in these cases decisions stick. But if the community mediators do not command this level of authority then cases can easily be contested and opened up again.
} 
Today's 'shopping' strategies annoyed many male respondents and account for why, when asked what the government could do to help improve access to justice, many said 'The Government must uphold and back decisions made by our Elders.' This shows that respondents want - but haven't currently got - a system with internal integrity so that decisions made at a lower (i.e. village) level are then backed by higher level authorities (the state). What people don't want is a linked system that allows earlier decisions to be overturned and the whole case opened up again; they want decisions to be final.

\section{Women Respondents}

Women respondents had quite different things to say about the community-based system. Those in the 'partial/sometimes' and 'do not trust' category (i.e. almost half) made a distinction between cases around land and property, which they thought the Elders handled fairly, and cases that involved women. In these cases they thought the application of Pastunwali principles allowed men to restore relations between themselves but at the expense of women's and girl's wellbeing. Women respondents talked at length about the ways they were used to settle disputes, pay off debts or 'sold' to old men to amass money for their brothers' brideprice. (The heroin economy has increased brideprice payments overall but particularly for second, third and fourth marriages, and whenever there is a substantial age difference.) Thus daughters are a substantial financial asset for a poor family. Those with personal experience of in-laws treating a bad girl cruelly particularly disliked the practice of bad, but other practices were mentioned more frequently and seen as equally unjust. ${ }^{23}$

Only when Shari'a was used as the basis of a judgment did women say they felt sure of getting fair treatment. However, as we have mentioned Pashtunwali principles normally dominates in rural Helmand. For women however Shari'a was a beacon of hope. They had no knowledge of Afghan law - no woman mentioned the law - but they believed that if Shari'a rather than Pashtunwali was used to adjudicate disputes then women and girls would be better off.

\subsection{Perceptions of Fairness (ii) the 'Government' System}

As mentioned previously we used respondents' own terminological categories when asking their opinions of different justice mechanisms and all respondents, without exception, used the term 'government system' to refer both to district level government representatives like District Governors, and statutory actors, i.e. the court system in Lashkar Gah (given that no respondent talked of meeting one of the newly posted District Prosecutors or the two District Huquqs). This conflation makes it difficult to identify who is being referred to given the many different justice actors in this category, and whether perceptions are based on recent or past experience.

As the graph shows there is little difference between men and women's perceptions of the 'government system': the vast majority saw it as 'not at all trustworthy/fair'. Most women had had no direct contact with government or statutory justice actors, but had heard how they operated.

\footnotetext{
${ }^{23}$ Three other frequently mentioned practices were:

- having to marry a man who already had multiple wives and then being treated badly by the husband and the co-wives (the dread of having co-wives was mentioned by almost every women interviewed)

- being forced to marry old men so their families could get a high brideprice (poor families want their daughters to bring in a substantial brideprice so it can be used for the brideprice/marriage of sons)

- being forced to claim their inheritance. At first glance this sounds a good thing but when women are forced to do this by their husbands it is not. Under Pashtunwali it is customary for a woman to abrogate her share of inheritance to her brother so that property stays within the paternal family; this also means she has a bolt hole to return to. By forcing a girl to ask for her inheritance (which she has a right to under Shari'a) her husband and in-laws benefit financially as the money passes to them. However, it means the girl gives up her right to be buried in her natal graveyard - and the right to call on her family for social protection. Women are therefore very reluctant to claim their inheritance as it is a form of personal insurance. However, they had little choice if their in-laws insisted.
} 


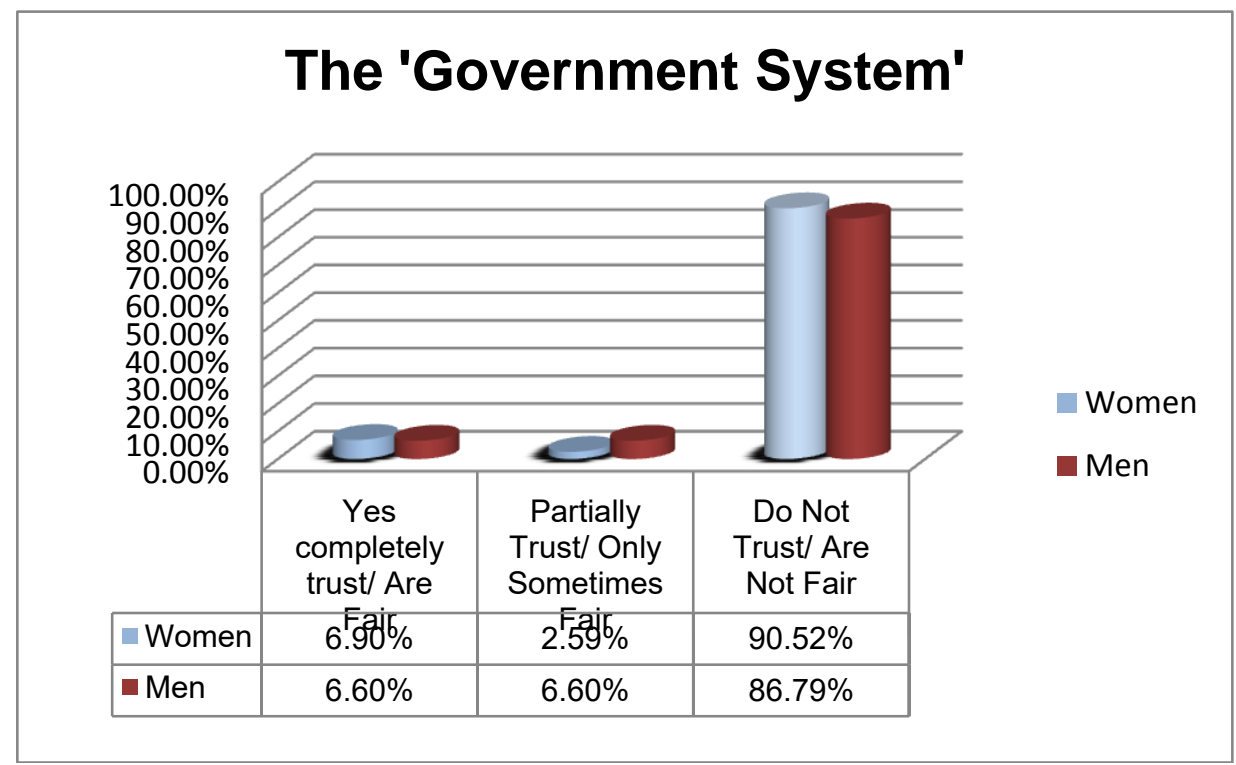

The problem for all respondents with the government system was the same: bribery and associated practices (favouritism, nepotism). Given the ubiquity of this 'bribery' label, and its importance in determining attitudes to the legitimacy of government, we asked respondents to give examples of what they meant. Four main extraction mechanisms were mentioned as commonplace. Although the quotes below relate mainly to what happens at district centre level (with the DG and district administration) respondents were sure that the court system in Lashkar Gah was 'worse'.

(i) Payments to progress cases. In all districts, informal payments in the justice sector start with the registration process. If no payments are made, or the amount is deemed insufficient, then the case stalls.

"Bribes start on the street when you file a complaint. You have to buy a stamp paper. The official price is 3 Afs but they sell it to you for 10 or 15 Afs. And then you need to write a petition and the writer gets money from you and then the first bribe is to the guards so you get in; then you submit your petition and the DG sends his secretary and says 'I will sign only if you pay this much'. So then he signs it and then the clerk asks for money so your case is registered in the book and you get a registration number. Then if you are sent to any other department you again pay the guard and then the head of that department will again ask for money for signing and it goes on and on." (Male respondent, Gereshk)

"If you go to the Government it takes a lot of time. The first day you will be rejected, the DG will be too busy, and will be told to come back. When you come back the Administrator is missing. You know then that they may be trying to fix a bribe amount with one of the parties. They might try to get some from both, hoping that one will then give more in the hope that the judgement will go in their favour." (Male respondent, Nawa)

(ii) Payments to keep the case out of the court system. Respondents in all districts noted that District Governors and their administrators use their pivotal position at the entry to the statutory system to extract rents. This is usually done through presenting disputants with a choice.

"The DG always gives an option, either you pay him and he will help solve it or you register the case and it gets passed to the criminal system where it will cost you more. In some cases it is the DG himself who offers this choice or sometimes the Administrator talks on his behalf.' (male respondent, Nawa) 
(iii) Payments to produce a favourable result for one party. Respondents gave many examples of one party bribing justice actors (the DG, the prosecutor, the judge in LKG) in order to ensure the ruling went in their favour. Hence the often-heard remark: "The government system is only for those with money."

(iv) Payments to get out of jail. Again, respondents gave many examples of a case going to court and the accused receiving a custodial sentence but getting out by paying a bribe.

"They convicted a person for murder from our village and imprisoned him a few months ago. And then a few weeks later we saw him here, in his shop, working as normal."

"Even if a person is found guilty by the court in LKG he won't stay in jail long if he has money. His relatives will come and they will pay and he will be released."

All these payments, although described as 'normal' practice for all government offices, were deeply disliked: they made the justice system time consuming and expensive. Most importantly, they undermined the whole idea of 'justice' because judgements could be bought and sentences shortened or circumvented if a large enough bribe was paid.

The one positive aspect of the government system, mentioned tentatively by a few women, was that they had heard it was fairer to women than the community system because it used Shari'a as a basis for judgements. This may explain why the few cases where women did try to get help they went to the District Governor, not to their Elders.

Although we noted earlier that Community Councils are normally seen as part of the 'government system', a few respondents noted that they were not including the CCs in this designation and did not see their Elders as corrupt. However, others said that once Elders became CC members some 'began to act like government', i.e. started to find ways to enrich themselves. This issue of Elders becoming contaminated by the endemic bribery in the government system when they take on CC member status is discussed in the next section.

It is important to note that despite the many negative comments about government and statutory justice actors those interviewed all wanted effective state justice. They know there are issues that the elders can't solve; they are unsure how well elder's decisions will stick; and there is a memory of when the two systems worked side by side and provided difficult civil and criminal cases with a final authority. In short, the many complaints that respondents had about 'government' was not a vote against statutory justice but rather their perception of how it currently operates.

\subsection{Perceptions of Fairness (iii) Taliban Dispute Resolution Mechanisms}

The majority of respondents, because they lived in government-controlled areas, had no direct and recent experience of Taliban justice. A few had - mainly those living in Musa Qala and Gereshk. Male respondents were nonetheless well informed about Taliban justice from bazaar conversations and women knew about it from hearsay. Everyone could remember the period of Taliban rule 1996-2001. 


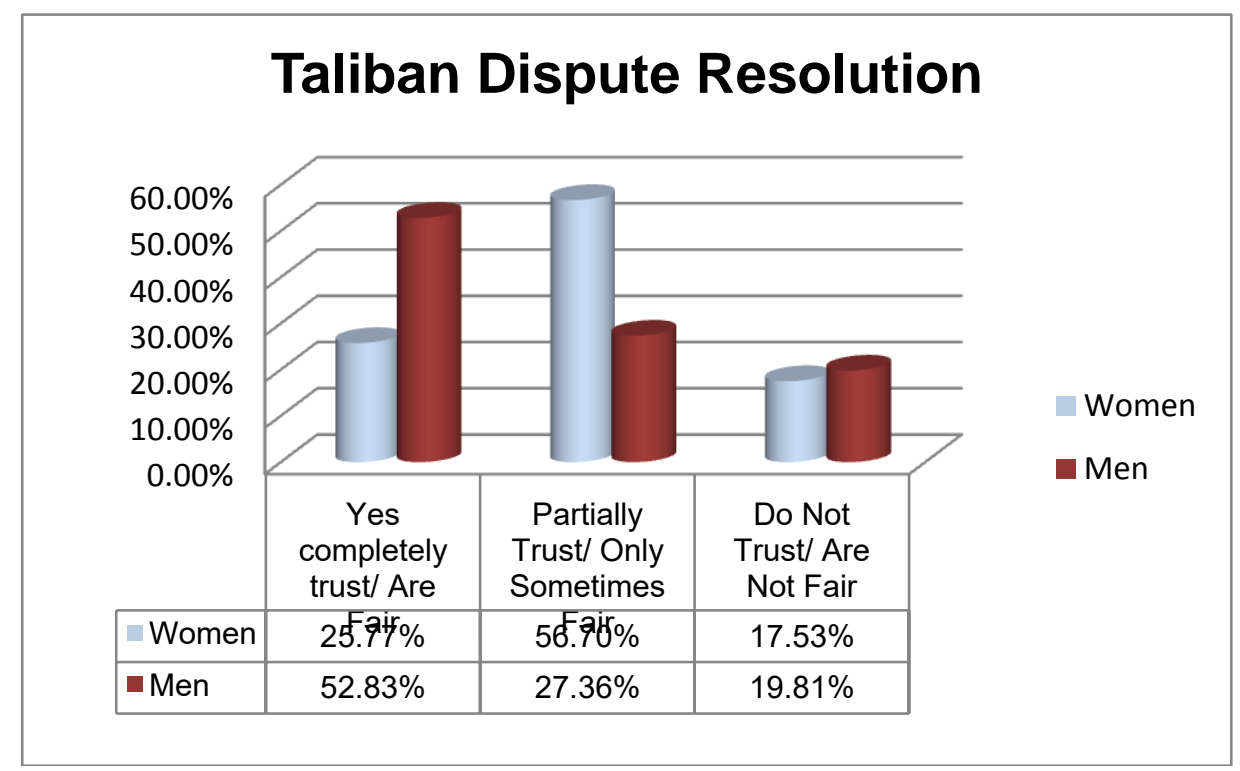

\title{
Male Respondents
}

Just over half of male respondents deemed the Taliban 'completely trustworthy and fair'; the rest were divided between those saying it was sometimes fair and those who said it was not fair.

Those supportive of the Taliban system saw it delivering exactly what the Elders could not judgements that could be enforced. People knew that the Taliban would punish anyone who did not honour the terms of a judgement - whether the case was heard by Taliban designated Mullahs, the Taliban mobile courts or the Justice Committee of the District Commission.

\begin{abstract}
"There was a dispute over land boundaries in Malgir village. They took it to the Elders but they could not resolve it. So they went to the government and both sides had to give a bribe and still they could not resolve the issue. So they went to the Taliban and they resolved it. The Taliban came over to the land and made a new demarcation so the owners now know their boundaries..... If the Taliban decide something then we know the parties will abide by it. There isn't this clarity with government, cases can go on and on." (Male respondent, Garamsir)
\end{abstract}

Other positives were that the Taliban system resolved cases quickly and, like community-based mechanisms, no payments were involved. Interestingly, some respondents noted that when the Taliban were in power their justice system could be as corrupt as that of today's 'government' system. However, they now never asked for payments when resolving disputes. That said respondents noted that they extracted money from people in many other ways - as ushr (agricultural tax), road tolls and zakat (charitable annual donation to the poor).

The downsides identified by male respondents were that decisions were made too quickly, which meant they didn't investigate all sides sufficiently so that judgements were not always fair. Also, punishments were harsh and whilst this had deterrent effect they didn't help reconcile the parties over time. A common view was that the Taliban 'aren't really interested in justice, they just use justice as a means of control'.

\section{Women Respondents}

The fact that the majority of women said that Taliban system was 'sometimes fair' related to what they had heard about Taliban decision-making: cases were dealt with quickly and their judgements were enforced - a good thing. However, women couldn't bring themselves to say the Taliban were 'fair' or that they trusted them in general. Women respondents remembered back to the days of Taliban rule and talked about how they had opposed things women held dearly: education for their children (boys and girls) and their own ability to travel and work if they wanted. Women acknowledged that their own 
family members were currently the ones restricting their movements, not the Taliban; nonetheless they didn't want the Taliban adding to their problems.

Although women had heard that the Taliban used Shari'a as the basis for their judgments - a positive thing from women's points of view - it was not the sort of Shari'a women wanted and felt was right. They had heard about the severe punishments, including of women, and could not believe that the Taliban were using 'real' Shari'a to judge cases.

As noted, very few people actually saw themselves as having a choice between the Government and Taliban systems. Who they went to was determined by where they lived - in a Taliban area you had to go to the Taliban; in a government area you went to the District Governor and from there to the courts.

\subsection{Summary}

1. No system is wholly trusted or seen as fair.

- Community based dispute resolution has strengths but also weaknesses - decisions made by Elders cannot be enforced whilst many women feel Elders' decisions sometimes take no account of women and children's wellbeing.

- The 'government' system (meaning DGs and District Administrations and the court system in Lashkar Gah) is the least trusted due to lack of access, the frequent need for bribes and the fact that it can be influenced by those with money or political power. Men and women want a functioning and fair statutory system.

- Although Taliban justice is quick and bribe free it is experienced as a control mechanism with harsh judgements that do not reflect Afghanistan's Hanafi-based Shari'a traditions.

2. The problem with the 'government' dispute resolution system is not that the Taliban provides an attractive alternative - it doesn't as it also has flaws. The real problem is that it is seen as based on informal payments and favouritism; it therefore has little legitimacy.

3. Men and women want a justice system that:

- is bribe free;

- has internal integrity. This means that decisions made by lower level authority (e.g. at community level) must be backed by, because they are consistent with, higher level authorities (e.g. the statutory system);

- can enforce decisions made. This is to avoid disputants unhappy with one decision shopping around for another mechanism that will favour them. (Basically people want to get on with their lives, not spend their whole time trying to get disputes resolved.)

4. Women and men can have different priorities when it comes to the principles on which they think cases should be adjudicated. The fact that women in Helmand are enormously restricted in their mobility does not mean that they have no opinions on how they think justice systems need to change. They are potentially strong supporters of rights based justice. Currently this is expressed as support for Shari'a because this is what they know. Men are more inclined to support the principles inherent in Pashtunwali, i.e. reconciliation and the maintenance of group honour.

5. Bad has received a great deal of attention in Afghan and international justice debates. However, an emphasis on this one practice detracts from the large number of other practices that women feel negatively affects their rights and wellbeing. The emphasis should not be on getting rid of bad as a stand-alone issue but on the raft of practices women identify as unjust. Currently women do not participate in justice processes as disputants or decision makers so cannot make their voices heard. (The imminent recruitment of a DFID Justice Advisor to the PRT, who will focus on women's access to justice, is important and timely in this regard.) 
This section first reviews the work of the government led and UK supported Afghan Social Outreach Programme (ASOP), specifically, the justice work undertaken by the ASOP Community Councils (CCs). It then goes on to consider the work of the UK supported Prisoner Review Shura (PRS). ${ }^{24}$ The aim of this review is to identify what a future phase of UK support might focus on. The implications of study findings for indicators used to assess the effectiveness of UK support to the justice sector are also considered.

\subsection{The justice work of Community Council}

Community Councils (CCs) operate in four of the districts covered by this study - in Garamsir, Gereshk, Nad-e Ali and Nawa. They comprise elected Elders that meet regularly in the district capital to discuss issues arising in their three designated areas of responsibility: justice, security, and social and economic development. Each of these areas has its own sub-committee but the major issues raised in each sub-committee tend to be discussed by the $C C$ as a whole. For this reason respondents tended to refer to 'the district shura' (i.e. the $\mathrm{CC}$ ) as a body without distinguishing subcommittees. We adopt the same practice in this section although the focus is their justice work.

CC members receive a stipend (currently $\$ 120$ per month - roughly twice the salary of a prosecutor) to cover travel and hospitality costs. Members attend meetings regularly as stipends are paid only on the basis of attendance. The UK also provides funds for projects identified by Community Council subcommittees in support of their district plans (up to $£ 250,000$ per district per year).

CCs in the districts covered by the study have been in operation since 2008 (Gereshk) and 2009 (the other districts). They are intended as temporary transition bodies that will be dissolved once District Councils have been elected under the forthcoming Sub-National Governance (SNG) act. District Councils are due to be phased in from 2010 but the timeline has slipped so the life of CCs may be extended for another year or so. Membership numbers will reduce when they are replaced by District Councils - from 35-45 (the size of CCs now) to 9-15 (the number of DC members envisaged in the SNG policy). District Councils will also have a mandate to hear dispute resolution cases so this aspect of $\mathrm{CC}$ work will be continued by DCs.

\section{The Justice work of Community Councils: Assessment Criteria}

The roles of the Justice Sub-Committee of Community Councils are spelt out in the Community District Plans developed by CC members during their initial training and planning workshops. These roles are reasonably similar across all districts and can be summarised as:

- To hear and resolve disputes,

- to ensure a link between communities, government and justice sector providers,

- to encourage and support those who currently solve disputes in communities,

- to promote respect for basic rights in communities,

- to increase the access of excluded populations to dispute resolution mechanisms.

We first assess the effectiveness of JSC/CCs against these criteria and then look at one other role that JSC/CCs have taken up in some districts: having an oversight/accountability role with regard to government services.

\section{(i) Solving disputes}

JSC/CCs do hear and solve disputes so are meeting this objectives. As mentioned earlier, CCs hear two sorts of cases - those referred by the DG, the police, Prisoner Review Shura and (now) prosecutors. They also hear 'first appearance' cases from residents living close to the district centre. However, the number of disputes heard and resolved is not large (on average 2-4 a month per district)

\footnotetext{
${ }^{24}$ The Independent Directorate of Local Governance (IDLG) is the lead government body co-ordinating ASOP whilst the Helmand PRT (Governance team) funds, trains and monitors the ASOP implementation team. Additional logistical and training support for the CCs is given by WADAN, a national Afghan NGO with offices in Lashkar Gah.
} 
and the number does not appear to be increasing. ${ }^{25}$ Indeed, as and when other parts of the justice system start functioning properly then we might expect the number of cases to decrease rather than increase - as a result of Huquqs and District Prosecutors becoming principal mediation, resolution and referral actors. This is not happening yet, but if it does in future it should be seen as an indicators of success for the justice sector as a whole, not a failure of CCs.

This means that assessing the success of JSC/CCs by the number of cases heard (a current indicator) is unwise as 'success' in other parts of the justice system should limit the need for them to play a major role in dispute resolution. However, it raises the question: by what measure should UK support to the justice work of CCs be judged if 'number of cases heard' is not a good indicator? We return to this question in the following section.

\section{(ii) Ensuring a link between communities, Government and justice sector support}

The idea of Community Councils providing a bridge between people and government is given as a major rationale for the establishment of CCs in UK project documents. However, although CC members themselves link with government it is not clear that this link then extends to people back in villages.

CCs are certainly an effective mechanism for linking the Elders on the CC with government and statutory justice actors. As mentioned JSC/CCs hear cases referred by DGs, Chiefs of Police, Prisoner Review Shura and prosecutors. Some links could be better developed, for example those between JSC/CCs and Huquqs. Because Huquqs advise and mediate on exactly the same cases as CCs (land and property disputes, inheritance and family issues etc.) there should be good links between them. However, although mapping study respondents remembered Huquqs in the past (in the early years of the Karzai regime) they did not mention having any contact with them today. In the future it may be worth the UK considering support for Huquqs given their important role in resolving civil disputes.

CCs have also been good for linking their members with DFID and PRT justice advisers and District Stabilisation teams. A great deal has been learned about justice processes in Helmand, and how communities think and operate, that would never have been gleaned without the CCs.

Whether CCs really provide a bridge between government and people seems to vary depending on who is speaking. Some respondents (who, it will be recalled all came from rural areas outside the district centres) were suspicious of CCs, claiming they were not representative because some senior elders had opted out of elections and that the DG's cronies had been appointed instead. Others felt CC members had been co-opted by government and its international partners by the promise of stipends and access to donor funds for projects. There were frequent comments that these were not being managed in a transparent fashion and that individuals were siphoning off funds or unfairly privileging the areas they came from.

A look at the Pashto blogs on Community Councils in different districts reflects similar concern over the integrity of some Elders once they become CC members. ${ }^{26}$ A TV programme on Gereshk Community Council recently broadcast on a Helmand channel (RTA) reflects comments made by many respondents in the mapping study. ${ }^{27}$ In the TV interview the Deputy of the CC made the point that "This Council is duty bound to bridge the gap between the communities and the government, and luckily, the CC has been successful in achieving this goal." However, this was followed by an interview with a member of the Security Sub-Committee who said "The CC is a showpiece and most of its

\footnotetext{
${ }^{25}$ It is difficult to say if there has been an increase in disputes heard by the JSCs/CCs since their inception. In Community Council records, JSC issues are not separated out from other CC business and it is often difficult to know what is a justice case and what has been bought by another sub-committee. Also, the level of literacy of those recording cases varies and it was difficult to find someone who could decipher some cases well enough to translate them. Note also that CC respondents in most districts said they heard around 2 cases a month but in Gereshk 5-6. Reported by Kate Fearon in 'Now she goes to School', October 2009

${ }^{26}$ See for example the blog on Nad-e Ali where Elders "accuse each other of misconduct, specifically about of having a role in the embezzlement of chemical fertilizer and seed, which was part of a food zone project funded by DfID". See the http://www.gramsar.blogfa.com/post-511.aspx

${ }^{27}$ This interview was broadcast on the Helmand RTA channel in the programme 'What do People say?' on 12th April at 7.30pm. The senior CPAU researcher who happened to be watching the programme took down a verbatim record of the interview.
} 
members, including me, are here only to receive 6000 Afs a month salaries and some other relief items like fertilizers.... This shura has in fact widened the gap between people and the government because it is a mechanism which allows us to grab whatever relief comes to the community from the government". Clearly, there are divided opinions on whether CCs are managing to be a bridge back to communities or whether their close association with government and their own malpractice is draining their legitimacy. ${ }^{28}$

So far, such accusations have been directed at CC Chairmen and/or members of the Development Sub-Committee and not the JSC. However, as noted, outsiders see the CC as one institution so that indiscretion by any one member impacts on the profile of the whole group. ${ }^{29}$

In other districts there is evidence to suggest that despite initial ups and downs, CCs are now bedding down. The recent re-election in Nad-e Ali bought 3000 men from across the district to a jirga to discuss the election process. It was hosted by the District Governor and organised with IDLG, WADAN and PRT support. It might even be that past reports of embezzlement in Nad-e Ali have actually raised ordinary people's interest in ensuring CC election processes are participatory and transparent. This may result in increasing public confidence in $\mathrm{CCs}$, including their justice work.

In summary, there are different opinions on the extent to which JSC/CCs are providing a link between people and government. Whilst CCs, government personnel and statutory justice actors can benefit from close association, they can also both lose legitimacy if malpractices occur and these are not dealt with using proper procedures.

\section{(iii) Supporting those in communities who currently resolve disputes.}

The thinking behind this objective is that if Elders and Mullahs in communities are supported to resolve cases fairly people will turn to them and this will strengthen the community-based system overall. The type of support and strengthening originally envisaged included providing information on legal and rights issues, providing an opportunity for referral of complicated cases, and providing assistance with enforcement of decisions by liaising with state institutions. ${ }^{30}$

To date support has been mainly at district level, to JSC/CC members, there has been very little outreach to the thousands of Elders and Mullahs in Helmand solving disputes in villages. In a future programme it will be necessary to identify and support local Helmandis to do make these contacts as security constraints mean PRT staff and District Stabilisation Team members cannot travel beyond the secured district centres.

\section{(iv) Promoting respect for human rights}

One of the initial ideas for Community Councils was that they would provide an opportunity to enhance the skills and knowledge of members. In the area of justice it was envisaged that training would be given to members of JSCs and the whole CC to extend members' understanding of Afghan law and Shari'a, and of individual rights.

\footnotetext{
${ }^{28}$ It may or may not be related but the Deputy of Gereshk CC was killed shortly after this interview was broadcast.

${ }^{29}$ This leads to another point. From an IDLG and UK perspective the embezzlement of funds by a CC Chairman (for example) could be an opportunity to show that justice can be done, for example, by activating a transparent and consultative procedure to investigate the charge and remove the individual if found guilty. Such action could result in strengthening public faith in CCs (and government) because people would know there are mechanisms in place to ensure they act in the public interest. However, we could not identify accountability mechanisms for CCs. The Provincial Governor has removed at least one CC Chairman for embezzling funds but this has not been done through a transparent process. He was simply removed and replaced. Given the overwhelming need to build public confidence in the government this is an opportunity forgone. A proper complaints and accountability procedure is needed to protect CC and government integrity.

${ }^{30}$ See Fraser Hirst's report 'Support to the Informal Justice Sector in Helmand - April 2009' for a summary of the initial vision for the justice work of CCs and what happened in the period up to mid 2009.
} 
Early reports suggest a large number of potential providers and facilitators for courses and discussions on human rights, including the Huquq Department of the MoJ, the Afghan Independent Human Rights Commission (AIHRC), defence lawyers, the Women and Children's Justice Group (now the ICWCR) and senior religious scholars. It was envisaged that after training for themselves the CCs would arrange a series of shuras in communities to disseminate main messages and lessons learned. ${ }^{31}$

Since 2007 there have been a number of training courses on rights run by different agencies, both state and non-state at provincial level. For example, the Huquq Department of the MoJ led three Legal Education Shuras in 2009; the regional AIHRC organised a training programme for the Provincial Ulema Shura in late 2008/early 2009; a representative from the MoJ conducted basic legal training in the setting up of the Nawa Justice Sub-Committee; JSSP are currently about to run a course to build the capacity in criminal justice. From what we could understand these events have been well attended and well received - the Legal Education Shuras bought together a total of 550 community elders in Lashkar Gah, Gereshk and Garamsir. However, we could find no information about what the outcomes of training had been. It is therefore difficult to say whether they have had any long term impact and have affected the way that disputes are adjudicated either by Elders and Mullahs or by statutory justice actors.

The 'Women's issue' has been raised with male audiences in some training but not in a serious way. One CC member told us that the facilitator of a recent training event in Garamsir had suggested to his male audience that they all say 'salam' to their wife when they returned home that evening. The next day the men confirmed that they had done this and, chuckling, said it had had some very positive results. A story to smile about perhaps but not an indication that CC members have yet engaged in a proper discussion of men, women and children's rights.

With the recent posting of two (soon to be three) PRT District Justice Advisers, and committed support for justice initiatives from District Stabilisation teams, there is now an opportunity to develop a much more comprehensive programme of education on human rights than has been possible in the past. Such a programme would need a comprehensive communication and outreach strategy and could involve several activities: for example, a training/learning course, an interactive radio programme, and visits by Helmandis to other provinces to discuss approaches used elsewhere. It would ideally be led by Afghan civil society and include respected and well-known religious figures. Facilitators of any training/learning events would need a good understanding of Shari'a and Afghan law as this applies to men, women and children's right as well as knowledge of how Pashtunwali is applied in different districts of Helmand.

\section{(v) Increasing access to justice for excluded groups}

As discussed, the $\mathrm{CC}$ in Gereshk district allowed women to be voted onto the Community Council. This was facilitated by two factors: the existence of a women's shura before the CC came into existence and the support given their election by the DG. There had been a woman District Stabilisation Adviser in Gereshk at the time and it was her support that got the women's shura up and running. This indicates the importance of having women on District Stabilisation teams as it is much more difficult for male advisers to communicate with women. The DG's support for the shura was also critical according to women members. The full Women's Shura has a steady membership of about 30 women who meet weekly, although they can muster 600 women to come for elections or specific projects. The Shura has been very influential in supporting women who would not otherwise go 'public' with their cases. By acting as intermediary supporters between individual women and the CC and other justice actors they have increased access to justice for women, albeit only for those who have been able to contact them.

There have been discussions within the PRT and Women's Shura itself as to how to best use the Gereshk experience to encourage men in other districts to also allow women's representation on the $\mathrm{CC}$. The fact that there is no demand from men in other districts for women's representation shouldn't be taken as an indication that this is impossible; women (and men) reported little appetite for women

\footnotetext{
${ }^{31}$ Fraser Hirst, ibid, 2009 
CC members in Gereshk initially too, but DG support helped overrule opposition. In a future phase of UK support consideration should be given to facilitating separate women's shura in as many districts as possible - wherever there is a demand from women for this. This needs to occur now, well before CCs are replaced by District Councils. The PRT Rule of Law and Governance sections need to make it a priority to push for women's involvement in future District Councils - having a pre-existing women's shura before the DCs come into being will provide a platform for women prepared to stand for elections. Hence the importance of getting women shuras established as soon as possible, whether or not the CCs support them.

The women leading the Gereshk Women's Shura now have considerable experience in operating as an active shura and in supporting women to resolve their disputes. They appear to provide an effective interface with different dispute resolution actors (village Elders, the JSC/CCs, the DG, the statutory system). They should definitely be consulted for their advice and experience in how to set up a shura in other districts, how to identify women who might lead it, how to gain the respect of the male community (as far as this is possible) and how to support women who approach the shura for help.

\section{(vi) Establishing the principle of accountability in basic services}

Although accountability work is more often associated with the Security Sub-Committees of CCs than the JSC, some JSCs have also taken this as part of their mandate. ${ }^{32}$ JSC members in Gereshk and Nawa districts have made visits to schools, hospitals and prisons to look at their physical conditions, whether staff are attending, what service is being provided, whether fees are charged and so on. It is not clear from CC reports (as these are patchy) whether these visits have been one-off events or if they take place on a regular basis.

Given that one of the functions of CCs is to provide a bridge between government and people then part of this bridge would ideally be around the issue of accountability. Ideally the CC would refer its findings to a statutory body that could then communicate with the appropriate line ministry/service provider. Although accountability visits by $\mathrm{CC}$ members to local services and facilities do indicate the beginnings of a watchdog role - one that is consistent with the proposed role for District Councils there need to be ways of addressing weaknesses identified if $\mathrm{JSC} / \mathrm{CC}$ visits are to have any positive impact on services.

A final note: the importance of record keeping and reporting has been noted throughout this section. The PRT and District Stabilisation teams have encouraged record keeping for all PRS and CC activities either by appointing Afghan organisations to do this (WADAN provides reports on CC meetings, translating some into English) or by taking this on themselves (PRS meetings). It is important that the PRT and District Stabilisation teams continue to emphasise the importance of record keeping and get intermediary organisations to translate at least some reports into English. In future reports need to capture problems as well as progress so PRT and DSTs can keep in touch with what is really happening.

\subsection{Summary}

1. Community Councils are new institutions; most have been in place for less than 15 months. At the outset they developed ambitious District Community Council Plans and set each sub-committee multiple objectives, including in justice. Progress against objectives is inevitably constrained by existing capabilities, the constraints of operating in a highly insecure environment, and the fact that DFID and the PRT can provide high quality but only limited support.

2. The Justice Sub-Committees are now achieving some of their basic objectives. They are hearing and resolving minor civil cases; one district has shown that if women are elected to CCs it can increase the access of women to justice; and links between the JSC/CC and some government and statutory justice actors are strong, indicating that community and state justice systems can link successfully at district level. This shows that progress has been made.

32 For example, the ANP Community Outreach Programme is supported by the Security Sub-Committees rather than the JSCs.
For a report detailing the work of the ANP Community Outreach Programme see Kate Fearon 'Building Community Confidence
in the Helmand ANP, April 2010
Coffey International Development 
3. UK support to CCs to date has focused mainly on getting CCs up and running as institutions and fulfilling basic sub-committee functions. Justice work has focused on the work of the Justice subcommittees in the district centres; there has been little outreach to the hundreds of mullahs and elders acting as mediators in villages. Local Helmandis will need to do this outreach as the security situation prevents the movement of District Stabilisation team and PRT members beyond the secured district towns.

4. Allegations of financial misconduct and favouritism by some CC members have impacted on public trust in CCs. This is a concern as it lessens their legitimacy and if not addressed through transparent procedures will undermine their ability to have a watchdog role, and to be seen as fair and impartial dispute mediators.

5. CCs are a potential entry point for engagement with Elders and religious leaders on human rights and basic legal concepts. Since 2007 there have been a number of provincial level training courses on rights run by different agencies, both state and non-state. A lack of data on what these courses covered makes it difficult to ascertain what their emphasis or outcomes have been. There is now a need - and an opportunity - to develop a comprehensive and co-ordinated legal and human rights programme of education that will target all three levels of community and statutory justice actors (provincial, district, villages) and to prioritise increasing awareness of women and children's rights amongst dispute mediators - but also the public in general.

\subsection{Prisoner Review Shuras (PRSs)}

Prisoner Review Shuras currently operate in three of the districts covered by this study: Musa Qala, Garamsir, and Nad-e Ali. One used to operate in Gereshk but has now been disbanded.

PRSs are meetings that bring together the Chiefs of Afghan Security Forces (the ANP, ANA, NDS) the District Governor and a community representative to review the evidence against those that have been arrested. The aim of these meetings is to ensure the police, army and intelligence services do not make arbitrary arrests, detain suspects in contravention of the 72 hour rule or order unlawful releases. After discussions in the PRS prisoners are released if there is no evidence against them or if it is deemed to be a minor crime. If there is evidence of a serious crime then PRS meetings provide an opportunity for security agency personnel to share this, thereby increasing the chance of a successful prosecution.

Like Community Councils PRSs were set up with PRT support as a transitional body to provide a transparent procedure for processing detainees in the absence of statutory mechanisms, i.e. a Prosecutor or Judge to process cases. There is a link with CCs - one member of the JSC participates in non-security related PRS meetings to provide community oversight and accountability. ${ }^{33}$ PRSs can and do refer minor cases to JSC/CCs for resolution.

Unlike CCs there is no financial incentive for members of the chiefs of Afghan security forces to participate in PRS meetings.

Assessing how well PRSs have worked, and whether they have achieved their basic objectives, is difficult because of patchy records. Even more than the CCs, PRSs have relied heavily on the presence of PRT and ISAF personnel acting as mentors, convenors of meetings and record keepers. Where international actors have not taken minutes, records have lapsed and it is difficult to find out if meetings occurred, let alone what was agreed/decided.

A brief summary of PRS activity for the four districts covered by this study is given in the table below. ${ }^{34}$ It will be noted that there have come to be two sorts of PRS: those hearing criminal cases and those hearing security/insurgency related cases.

\footnotetext{
${ }^{33}$ Prisoner Review Shura Procedures are given in Fraser Hirst, ibid, 2009, Annex III

${ }^{34}$ Reports by Kate Fearon and Sarah Maquire (Rule of Law team, HPRT) provide the basis for this table.
} 


\begin{tabular}{|l|l|}
\hline District & Brief history of PRS activity in districts covered by this study \\
\hline Musa Qala & $\begin{array}{l}\text { PRS established by ISAF in Nov 08, the oldest one. Excellent start, 54 cases heard up } \\
\text { to 12/09. After that no records due a change in ISAF personnel. Now no PRS as such } \\
\text { but a 'Detention Activity Shura', i.e. a weekly review of all those arrested in the period as } \\
\text { part of a mentoring exercise by Ministry of Defence Police. }\end{array}$ \\
\hline Nad-e Ali & $\begin{array}{l}\text { Heard 15 cases in the first few months of its life but then went defunct due to a change } \\
\text { in Chief of Police. Difficult ANA/ANP relationship and related removal of DCOP and } \\
\text { replacement by someone without sufficient authority meant the PRS did not regain } \\
\text { traction in Nad-e Ali. Capable Prosecutor now in post so criminal PRS has stopped } \\
\text { functioning but meeting held in 3/2010 to discuss reviving the PRS for NDS/insurgency } \\
\text { cases. }\end{array}$ \\
\hline Garamsir & $\begin{array}{l}\text { Records suggest PRS has met } 8 \text { times since July 2009 and dealt with 43 cases, all but } 7 \\
\text { insurgency related. Always attended by members of the District Stabilisation team; } \\
\text { judged to be very successful. }\end{array}$ \\
\hline Gereshk & $\begin{array}{l}\text { Gereshk PRS is not operating now. Met regularly initially, but then only once since Oct } \\
\text { 2009 because the Prosecutor arrived. However he wasn't able to effectively take over } \\
\text { the PRS role. }\end{array}$ \\
\hline
\end{tabular}

Interviews with PRS members in different districts (the District Chief of Police, Head of the ANA and NDS), and with Stabilisation Advisers and the PRT Rule of Law team suggest that when PRSs have operated they have done a good job. PRS members interviewed confirmed that they do result in the release of prisoners when there is insufficient evidence to continue holding them, but also in the continued detention of people against whom there is evidence of a serious crime. Records confirm that this actually happens. PRSs have also allowed for better information sharing on suspects and stopped prisoners being sent to LKG when there is no evidence. As one respondent remarked:

"The Prisoner Shura is good. Like today xx (suspected insurgent) - we needed more information about him - and we all shared our information and ideas. The shura decided we still needed to know more. This is good because it makes us sure we have enough proof (for a conviction)". (DCOP, Garamsir)

PRT and stabilisation advisers familiar with PRSs felt that in addition to the practical benefits of PRSs (ensuing people aren't left to languish in jail, including when there is no evidence against them) PRSs were helping to establish certain principles. These were that:

- Prisoners should not be detained beyond 72 hours. Even though this is not always followed in practice (even when regular PRS meetings are being held) the existence of the PRS sends a message that this is the law;

- relatives, local community and ISAF should be able to ask about detainees and get answers, i.e. PRSs are a step towards transparency;

- there should be no political or other interference in the criminal justice process;

- all security forces should operate within the law and be accountable.

In trying to further assess their value the following points came up in discussions about how PRSs have developed and operated, and what they have achieved. 
First, several of those interviewed remarked that the fact that PRSs have got off the ground at all is extraordinary, given institutional disincentives. Transparency is not a feature of any of the Afghan security services, so information sharing is not a given, indeed the tradition is to jealously guard information about suspects, not share it. Also, each service has its own rules and procedures with regard to detentions; the idea of Security Chiefs being willing to share procedures and therefore give up a degree of autonomy is a first. Also, detentions are an excellent way to extract rents from those detained or from families wanting their family members released; PRSs will have undoubtedly impacted on the amounts of informal money made by security force personnel. Add to this the logistical difficult of getting at least three senior government officials (2 Afghan National Security Force Chiefs and the DG) together in one room for every meeting and it is remarkable that PRSs is some districts have seen extended periods of operation.

Second, and this follows from the first point, PRSs have tended to operate only when there has been committed and active District Stabilisation presence. Thus the Garamsir PRS has operated reasonably consistently for the last 10 months but this is mainly because every meeting is attended by the Stabilisation Adviser and/or the US State Department representative. This inevitably raises the question as to whether PRSs are sustainable without an international presence - but also whether this matters, i.e. whether the PRS principles have become sufficiently inculcated for it not to matter if the PRS 'falls away', for instance, where a Prosecutor is established. We have insufficient data on either question to answer it: the international presence seems essential for record keeping but lack of records does not necessarily mean a PRS has stopped operating. And we have no way of gauging if PRS principles have been inculcated in the Chiefs of Security Forces; our interviews with them suggest this is so, but then they would have been unlikely to say otherwise.

A third point relates to the fact that as soon as a Prosecutor has taken up his post in a district the criminal PRSs have tended to stop operating on the basis that it is the Prosecutor's job to proceed with cases or release detainees. PRSs have therefore, over time, become mainly for suspected insurgency cases not 'ordinary' criminal ones. However, Prosecutors haven't been able to take the place of the PRS in some districts. Either they have not yet established themselves within the district or they have been sidelined by District Chiefs of Police (DCOP) who see them as a threat to their authority. DCOPs can (illegally) deny Prosecutors access to 'their' detainees or, if need be they can label their detainees 'Taliban' and have them transferred to the NDS. Because Prosecutors have no jurisdiction over security detainees this effectively cuts them out of process and puts an end to their watchdog role. It is for this reason that some commentators have suggested PRSs for criminal cases should be continued even when Prosecutors arrive in post.

As noted, the job undertaken by PRSs for criminal cases is legally that of Prosecutors; PRSs were established as interim bodies pending the posting of Prosecutors to districts. Once a Prosecutor is appointed to districts he takes over the PRS role for criminal detentions but the PRS has tended to be kept on to review security cases. No-one from the JSC/CCs sit on these cases as the information is confidential. Although the NDS were as resistant to the idea of PRSs as other Afghan Security forces when they started off some security chiefs (in Garamsir, Nad-e-Ali and Sangin) are showing signs of welcoming the PRS process for insurgency cases. The reasons for this vary: for some, it is a way of staying closely involved with ISAF; others recognise that the PRS supports the local NDS where the latter is weak while others may feel that it gives them the community support and credibility that they need to function effectively. ${ }^{35}$ PRSs for security cases therefore continue to be held in some districts (e.g. Garamsir). In Musa Qala there is no PRS as such but, until recently, there was a weekly review of all detainees as part of the mentoring role by MoD Police Officers. This has ceased with the advent of United States Marine corps control of the area.

\footnotetext{
${ }^{35}$ Reflects discussions with Kate Fearon as to why some NDS personnel seemed to have come round to the idea of PRSs.
} 
A final point: PRSs only operate at district level, not in Lashkar Gah. When suspects are transferred to Lashkar Gah they can still be detained there for long periods without trial and without sufficient investigation of the evidence. What this means for ordinary families (and especially poor ones) is captured by the following quotation from the mapping study. It is a long quote but it captures the misery experienced by parents whose son is detained and to whom they are then denied access.

"I am a very poor woman and my husband is very old and my husband is deaf and we have poor eyesight. We have a son who is driver and he was driving for someone else and he provides our food. One day he was going to take some goods to Gereshk and on his way to the house of the truck's owner he was stopped by Taliban and asked for a lift and since he was not armed he had no option but to stop the car and take them. The Taliban asked him forcibly to take two Punjabi men to a place. After 10 minutes drive they were stopped by Coalition troops and they arrested all of them and they implicated the driver in that as well and imprisoned him. Since that time we have no news from him and do not know where he is. We went to the DG and to the shura and to the NDS and we said 'You all know our son he is poor and he is not involved in such issues'. Then we went to Lashgar Gah and to the court and when the judge saw our poor appearance he asked the guard not to let us in. They even didn't allow us to enter the grounds of the court. Now it is four months since our son was imprisoned and we have nothing to eat because he was our provider and no-one listens to us." (Woman respondent, Gereshk district)

\subsection{Summary}

1. Prisoner Review Shuras were set up as temporary mechanisms to prevent arbitrary arrests and illegal detentions by Security Forces.

2. They have had an impact: prisoners have been released when there is insufficient evidence to hold them and they have allowed for information sharing on suspects. They may have helped establish certain principles: that the 72 hour detention rule should be respected; that relatives should be able to get information about detainees; that security forces are accountable to the law and that there should be no political or other interference within the criminal justice process.

3. There were many internal disincentives to overcome in getting PRSs accepted and used. PRT District Stabilisation team members have consequently had to provide a great deal of hands on facilitation and mentoring to keep them going and make them work.

4. In districts where Prosecutors have taken up their posts PRSs for criminal cases have stopped operating. But Prosecutors haven't always got the political clout to get District Chief of Police cooperation. In retrospect it may have been premature to stop PRSs for criminal cases before it was certain that Prosecutors could take over their role. This is a matter for negotiation between the District Prosecutor and DCOP with support from the District Stabilisation Teams.

5. PRSs do not operate in newly secured areas - but could usefully do so - or in Lashkar Gah due to the presence of the statutory justice system there. There is also problem of transparency and the tracking of cases in LKG.

6. PRSs can be criticised for being a foreign imposed mechanism that has no legal basis. However, had respondents in the mapping study known about the PRSs (they did not) they would very probably have supported them. This is on the basis that any intervention that decreases arbitrary arrests and detentions by security forces, Afghan and foreign, is welcomed. 
This section draws the implications of study findings by responding to specific questions in the TOR and posed by DFID and PRT staff during the study. This section therefore functions as a summary of findings that relate to specific concerns of UK and PRT personnel.

\subsection{WHAT ARE THE CHARACTERISTICS OF THE DIFFERENT DISPUTE RESOLUTION MECHANISMS OPERATING IN RURAL HELMAND? WHAT IS WORKING BEST AND FOR WHOM?}

The characteristics of the different dispute mechanisms as perceived by mapping study respondents are summarised in the table below. What 'works' depends on who is speaking; there are some sexspecific differences in perspective. Overall community-based dispute resolution is currently working best - in the sense of having higher levels of legitimacy than either the state or Taliban. That said it also has drawbacks that must be addressed if women, men and children are to get justice.

Table 1. Characteristics of different justice systems as perceived by respondents

\section{The Community-Based system}

\begin{tabular}{|c|c|c|c|c|}
\hline $\begin{array}{l}\text { Who may be } \\
\text { involved }\end{array}$ & $\begin{array}{l}\text { Basis of } \\
\text { judgements }\end{array}$ & $\begin{array}{l}\text { Perceived end } \\
\text { goal }\end{array}$ & Characteristics & Application \\
\hline $\begin{array}{l}\text { - Senior family } \\
\text { members } \\
\text { - Local elders } \\
\text { - Local mullahs } \\
\text { - Other respected } \\
\text { high status persons, } \\
\text { e.g. Tribal leaders, } \\
\text { Sayeeds, Maliks } \\
\text { Note: can be frequent } \\
\text { interaction with 'Govt' } \\
\text { e.g. DG, Land } \\
\text { Registry, CC, Huquq } \\
\text { Rep, Prosecutor etc. }\end{array}$ & $\begin{array}{l}\text { - Pashtunwali } \\
\text { - Shari'a } \\
\text { - Local custom } \\
\text { (often a } \\
\text { combination; } \\
\text { depends on } \\
\text { the issue and } \\
\text { who } \\
\text { adjudicates) }\end{array}$ & $\begin{array}{l}\text { Pashtunwali: to } \\
\text { preserve group } \\
\text { honour; to } \\
\text { reconcile } \\
\text { disputants } \\
\text { Shari'a: to give } \\
\text { individuals their } \\
\text { rights under } \\
\text { Islam } \\
\text { Local/tribal } \\
\text { precedent: to } \\
\text { preserve } \\
\text { existing } \\
\text { ways/values }\end{array}$ & $\begin{array}{l}\text { - Avoids courts } \\
\text { (public/slow/ costly) } \\
\text { - Adjudicators } \\
\text { (Elders/Mullahs) are } \\
\text { respected } \\
\text { - BUT judgements } \\
\text { don't always stick } \\
\text { - Judgements mostly } \\
\text { considered fair } \\
\text { - BUT women want } \\
\text { Shari'a applied, not } \\
\text { Pashtunwali for rights } \\
\text { cases }\end{array}$ & $\begin{array}{l}\text { - First dispute } \\
\text { resolution step in } \\
\text { Govt and TB } \\
\text { controlled areas. } \\
\text { - In Govt } \\
\text { controlled areas } \\
\text { next step is DG + } \\
\text { statutory system; } \\
\text { in TB controlled } \\
\text { areas next step is } \\
\text { TB mechanisms. }\end{array}$ \\
\hline
\end{tabular}

2. Government actors + the Statutory Justice System (conflated by respondents)

\begin{tabular}{|c|c|c|c|c|}
\hline Who may be involved & $\begin{array}{l}\text { Basis of } \\
\text { judgements }\end{array}$ & $\begin{array}{l}\text { Perceived } \\
\text { end goal }\end{array}$ & Characteristics & Application \\
\hline $\begin{array}{l}\text { a) DG and district Admin. } \\
\text { Includes Land Registry } \\
\text { and JSC/CC } \\
\text { b)Justice personnel } \\
\text { (when present): } \\
\text { prosecutors, judges, def. } \\
\text { lawyers, courts } \\
\text { c) Security institutions } \\
\text { (ANP, ANA, NDS, ISAF, } \\
\text { Marines) }\end{array}$ & $\begin{array}{l}\text { - Afghan } \\
\text { National law } \\
\text { - Formal and } \\
\text { informal } \\
\text { practices of } \\
\text { govt and } \\
\text { international } \\
\text { institutions and } \\
\text { officials }\end{array}$ & $\begin{array}{l}\text { - To extract } \\
\text { money from } \\
\text { disputants and } \\
\text { their families } \\
\text { (govt bodies) } \\
\text { - To punish } \\
\text { wrong doers } \\
\text { (court system) }\end{array}$ & $\begin{array}{l}\text { - Slow, corrupt, } \\
\text { untrustworthy - a } \\
\text { system 'for those } \\
\text { with money' } \\
\text { - But some } \\
\text { individuals can be } \\
\text { trusted } \\
\text { - If it worked well } \\
\text { could/should be the } \\
\text { final arbiter of } \\
\text { disputes }\end{array}$ & $\begin{array}{l}\text { - Accessed by } \\
\text { those in govt } \\
\text { controlled areas - } \\
\text { but little by those } \\
\text { outside } \\
\text { - Note: CC/JSC } \\
\text { seen primarily as } \\
\text { a government } \\
\text { body (a group of } \\
\text { Elders around the } \\
\text { DG) }\end{array}$ \\
\hline
\end{tabular}


3. The Taliban system

\begin{tabular}{|c|c|c|c|c|}
\hline Who may be involved & $\begin{array}{l}\text { Basis of } \\
\text { judgements }\end{array}$ & $\begin{array}{l}\text { Perceived end } \\
\text { goal }\end{array}$ & Characteristics & Application \\
\hline $\begin{array}{l}\text { - Taliban commanders } \\
\text { - Taliban designated } \\
\text { elders and mullahs } \\
\text { In some districts: } \\
\text { - Mobile court (uttaq) } \\
\text { - Justice Committee of } \\
\text { District Commission } \\
\text { - Quetta Shura (final } \\
\text { referral) }\end{array}$ & $\begin{array}{l}\text { Shari'a } \\
\text { (But note: } \\
\text { Taliban } \\
\text { interpretation } \\
\text { of Shari'a } \\
\text { referred to } \\
\text { negatively as } \\
\text { 'Wahhabi' by } \\
\text { some Elders } \\
\text { and feared by } \\
\text { women) }\end{array}$ & $\begin{array}{l}\text { - To maintain } \\
\text { control over } \\
\text { people, } \\
\text { including by fear } \\
\text { and force }\end{array}$ & $\begin{array}{l}\text { - Quick } \\
\text { - No bribe } \\
\text { - Can make } \\
\text { judgement stick by } \\
\text { threat/force } \\
\text { - Based on Shari'a } \\
\text { - BUT process also } \\
\text { based on fear; } \\
\text { decisions can be } \\
\text { too quick; hudud } \\
\text { punishments brutal }\end{array}$ & $\begin{array}{l}\text { - Taliban will } \\
\text { insist people use } \\
\text { their justice } \\
\text { system in areas } \\
\text { they control (no } \\
\text { choice) }\end{array}$ \\
\hline
\end{tabular}

\subsection{What would persuade people to stop using the Taliban system?}

This question assumes that people voluntarily choose to use the Taliban system. We found little evidence for this. Those in Taliban areas must use Taliban justice or risk retribution. Those living in government-controlled areas will generally use government systems because, despite known downsides (need for payments, slow processing of cases), it is accessible (the DGs door is always open) and it is based in the district centre which many men visit anyway - for the records office and more generally for the bazaar. ${ }^{36}$

Lack of public trust and confidence in the non-Taliban mechanisms (both the community mechanisms and the state system) will play into the hands of the Taliban and tend to strengthen the Taliban's role as a justice provider. The key is therefore to increase public trust in non-Taliban mechanisms as a whole. This means that the recommendations in this report for addressing the weaknesses in the community mechanisms must be viewed as a component of a wider justice strategy which must necessarily include the provision of support for the state system and efforts to strengthen links and accountability between the community and state system.

\subsection{There is clearly a difference between women and men's experience of the justice system. What is the crux of the issue here - and what can be done to increase women's access to justice?}

The mapping study has indeed highlighted differences between women and men's access to justice in Helmand and how they experience dispute resolution. Not all of this is about the justice system per se. As the findings show, women (and children) have no independent authority in most of Helmand, they are the 'property' of families, lineages and sub-tribes. Only women who are educated or in jobs (mainly as teachers) have some freedom of movement. The problem here is therefore much wider than the justice system; it is, as women respondents said, 'the attitudes of our men'. If the aim is to help empower women in Helmand then this needs a separate programme of support to civil society with this as its principal aim.

\footnotetext{
${ }^{36}$ The only time we heard of individuals voluntarily using the Taliban was when one disputant thought he would get a more favourable outcome if the Taliban decided the case on the basis of Shari'a. The problem was he had to persuade the other party to use the Taliban system also, which wasn't easy as the other side had realised they would do better staying within the community based system and having the case adjudicated on the basis of Pashtunwali.
} 
The justice sector is also a problem for women and in two main ways. The first is that most women have no direct access to it. They need intermediaries, other women who are more able to operate more publically than themselves to whom they can go for referral advice, and who are also respected by the wider community of men. This is exactly the role played by the Women's Shura in Gereshk. Going forward we need to ask: a) Can other CCs be persuaded to accept women as members? b) If not can women's shura be established independently of CCs in all districts to make it more likely that women will eventually be elected to District Councils? And c) Are there other ways to increase women's access to justice, for example, could intermediary women work alongside male paralegals in locations women visit? In other words, if we want to find ways of supporting women and children get justice then practical ways can be found to do this. The mapping study has been extremely useful in identifying just how restricted women's lives are in Helmand, but also their desire for change and practical ways of supporting them.

The other issue involving the justice system is $b a d^{37}$, and giving daughters to settle a debt. ${ }^{38}$ Practical ways of addressing the bad issue exist and would have the support of some men/elders. ${ }^{39}$ In the mapping study several men said that they thought serious disputes should be resolved by giving money or land to the wronged family, not a girl. We recommend a comprehensive programme of human rights education in the Executive Summary. This would need to involve respected religious leaders who can argue for the use of Shari'a in the mediation of disputes.

\subsection{Are the Justice Sub Committees and Prisoner Review Shuras well thought of and understood? Is current support having an impact on people's ability to access fair justice?}

The justice work of JSC/CCs appeared to be well understood by male respondents - most knew elders on the JSC/CCs and knew they resolved disputes. CC members themselves described CCs as bridges between themselves and government (quoting the words from their district plans). However, as noted, some mapping study respondents were less enthusiastic about CCs and felt their close relationship with government was having a corrupting influence. One thought that CCs were actually widening the gap between people and government.

Study respondents did not mention PRSs. PRSs are closed meetings between security force personnel and there is no reason the general public should know about them. That said it would be extremely useful if they did know about PRSs as it would send a message that Afghan security forces and ISAF were intent on holding themselves to account and abiding by the law. The apparent lack of public knowledge about PRSs indicates that in districts where there is a JSC member on the PRS, he is not proactively publicising the work of the JSCs on detentions. This could be a missed opportunity to advertise efforts to make the security forces accountable and to increase transparency around detentions.

What has been the impact of current support? Insofar as the JSC/CCs are hearing cases in all districts, even if only a few, they are giving people a chance to have minor civil cases heard at district level and stop them being referred to LKG. But as argued earlier the main significance of JSC/CCs for justice is not the number of cases heard. Rather it is their ability/potential to a) bring women into the frame (hence the importance of the model provided by Gereshk) and b) be the main recipients of messages around human rights and a conduit for taking these back to communities. As noted in the main text this potential has not yet been realised but it could be in future.

\footnotetext{
${ }^{37}$ Girls and women are normally used to reconcile parties when there has been one or more killings, thus where there is a lot of murder there tend to be a lot of bad. Hence, its reportedly common use in Musa Qala but rare use in Garamsir, discussed in annex 2.

${ }^{38}$ The frequency of this practice appears to be related to the amount of speculative borrowing against the price of opium. Men borrow money to buy opium in the hope the price will increase; if it doesn't and they cannot repay the loan then the elders will normally decide they have to give a daughter instead. Alternatively a man may decide to give his daughter in marriage to a very elderly man, knowing that the brideprice will be several times its normal amount - this is another way of dealing with unpaid loans.

${ }^{39}$ Some male respondents were themselves against bad, they thought it was a practice that was unkind to girls and did not always work because ill treatment of bad girls further exacerbated enmity between families.
} 
PRSs have impacted positively on people's ability to get justice insofar as they have ensured prisoners have been released if there is insufficient evidence to hold them. They have also made for more frequent communication between security force chiefs - and may have persuaded them that transparency has benefits.

\subsection{Is current DFID and PRT supported work on justice in Helmand aligned with the draft national policy? What future approaches/actions might help align UK support even more closely with policy principles?}

The draft national policy on 'Relations between the formal justice system and dispute resolution councils' (i.e. community-based dispute resolution) basically argues three things. First, Afghanistan's justice system is comprised of both 'informal' and 'formal' systems and access to both needs to increase. Second, informal mechanisms need to be strengthened so they are consistent with Shari'a, the Constitution and other Afghan laws, and international human rights standards; and that women need to participate as disputants, witnesses and decision makers. Third, the two systems need to link effectively.

Is UK support aligned with the draft policy principles? Yes, and this report has highlighted instances: for example, Prisoner Review Shura have increased access to justice for those arrested; support to $\mathrm{JSC} / \mathrm{CCs}$ has provided a mechanism for resolving civil cases at district level. ${ }^{40}$ However, the issue is perhaps not 'whether UK support is aligned with draft policy principles,' but whether UK support can also demonstrate how these principles might be actioned in practice.

This report has recommended how future UK support could help action/pilot two of the draft policy principles in the Helmand context. First, the principle of increasing access to justice for women could be advanced by supporting women to become adviser-intermediaries and disputants (principles 1 and 6). Second, the principle of making community-based mediation more consistent with Shari'a, the Constitution, and Afghan and international law and standards could be advanced by piloting a programme in human rights for elders (principal 2). Details of what these programmes might involve are discussed in the recommendations given in the Executive Summary.

\subsection{Do findings of the mapping study point to any particular issues that the draft policy Working Group might want to consider as the draft policy informs the new law?}

The findings of this study are relevant to the draft national policy in several ways.

1. Recognition of community-based mechanisms. The fact that the draft policy fully acknowledges the role and usefulness of community based dispute mechanisms is positive - in Helmand these are indeed the most trusted mechanisms for dispute resolution throughout the province, and the first port of call for almost all disputes, including in Taliban controlled areas.

2. Registration. Mandatory registration of all cases resolved through community-based mechanisms with 'a related government authority' is both impractical and unnecessary. Travelling to the district centre to register every small case from outlying villages would be dangerous (due to the security situation) and time-consuming. And it is unlikely that villagers would see a need if the Elders and/or Mullah had resolved the case to the satisfaction of both parties. However, for larger cases the right of one or both parties to voluntarily register the case might be very useful as a basis for the enforcement of the decisions of Elders and Mullahs in the state system, as well as helping prevent dissatisfied disputants shopping around for a decision that is more favourable to them. In other words registration could help to enforce and back the decisions made by Elders - a demand of many respondents in this study. For registration to work in practice it would need to: a) be the voluntary decision of one or both parties; b) take place after a judgement had been made and both parties had

\footnotetext{
${ }^{40}$ Many other aspects of PRT work increase access to justice but are not covered in this report. These include the Prosecutors programme (facilitating the transfer of Prosecutors to districts), police training, police mentoring, mentoring and training of lawyers, judges, prosecutors and defence lawyers, support to justice infrastructure including prisons and courthouses. A refuge for girls and women is planned for Lashkar Gah.
} 
signed saying they would abide by its terms; c) involve a speedy and free process; and d) involve no demand for informal payments.

3. Validation. The same argument applies here as to registration: requiring decisions made by Elders and Mullahs to be vetted by the statutory system and then validated is impractical and unnecessary. That said, preventing the abuse of human rights in community-based decision-making is very important. The issue is how to encourage communities (including but not only elders and mullahs) to appreciate that giving girls in bad is against Islam and that alternatives reconciliation processes exist and are used elsewhere. A combination of processes are needed to achieve this change:

- Make bad illegal under Afghan law (so that the law is consistent with Shari'a and international human rights standards);

- implement a public education campaign accompanied by messages from respected Ulema so that Elders and Mullahs - and the public in general - know that bad is not allowed in Islam and that alternative means of dispute reconciliation must be used instead (typically the transfer of property or money). Communicating this message in terms of Islam and Shari'a will have significant resonance with villagers;

- Implement a comprehensive programme of human rights training for community dispute mediators - of the type recommended in this report. As awareness increases amongst community mediators about bad we would expect Elders and Mullahs themselves to stop using girls and women to settle disputes - as is reportedly the case in other provinces; ${ }^{41}$

- Instigate and communicate a clearly defined appeals procedure - in order to protect the rights of individuals there must be provision for any party to a decision made by a community based mechanism to refer the case to the statutory system (for example in cases where there are alleged irregularities such as fraud, duress, coercion, bribery, corruption or alleged contravention of Shari'a, Afghan law or international human rights standards).

4. Criminal Cases. The issue of whether the community based dispute resolution mechanisms should be allowed to hear criminal cases is being hotly debated by Afghan and international justice specialists. We report what mapping study respondents said about this issue so that their voices can be taken into account.

Respondents in villages were used to their Elders hearing criminal cases. These usually involved assault or accidental or purposive killings that occurred when civil disputes (over land for example) got out of hand and the parties fought to defend both their property and their honour. The initial dispute may be between individuals but it can quickly broaden out to include a large number of kinsmen.

Respondents did not see prison sentences as 'settling' disputes between two parties. Several respondents noted that imprisoning a man for an accidental killing - or even a purposive one - does not settle the dispute; there were cases of men being imprisoned for years but the dispute immediately starting up again on their release because there had been no participatory reconciliation process. Nor does a prison sentence take account of the position of the man's wives, children and other dependents and how they are to support themselves during his absence. From the perspective of those interviewed for this study therefore, it was better to allow Elders and Mullahs to adjudicate cases involving killing when this occurred as a result of a dispute between two parties as it was more likely to stop the escalation of violence, reconcile the two sides, and allow the more guilty party to continue to support their dependents. We might also add - drawing on women's voices in particular - that reconciliation should be achieved through an agreement on the amounts of money and property the guilty party should pay to the other; girls and women should never be used in lieu of a monetary payment.

\footnotetext{
${ }^{41}$ Respondents in Deborah Smith's Nangahar study report that bad is decreasing (Smith 2009); she finds the same in Kandahar (personal communication, July 2010). The incidence of bad in the five districts covered by this study is discussed in Annex 1 . A complicating factor is that whilst men said its incidence was decreasing in some districts (e.g. Gereshk) women respondents disagreed.
} 
The above observations do not pronounce on the mechanisms of how the issue of criminal cases should be dealt with in the new law. It is, however, clear that it would not appear practical, feasible or in accordance with community desires to try to prevent community mechanisms from dealing with criminal matters. Further, the examples from the study stress the importance to ordinary people of the new law taking account of issues of reconciliation and social protection - which punishment by incarceration does not - both for civil disputes with criminal components and for criminal cases with civil/compensatory components. Study findings indicate that when Elders and Mullahs resolve such cases there is a good chance of achieving long lasting peace.

\subsection{What do study findings say about justice indicators that might be used for the Helmand Institution building Programme supported by DFID?}

This study was tasked with helping to establish baselines for the HIBP logframe as they apply to community-based justice.

One way of categorising indicators that could be used to estimate progress on the increased access to fair justice (specifically dispute resolution) in Helmand is to divide them into:

- Public perception indicators that measure degrees of trust and perceptions of fairness in different dispute resolution mechanisms;

- supply indicators that measure both the availability of dispute resolution mechanisms to previously excluded groups and changes in practice due to increased awareness of human rights by mediators;

- demand indicators that measure an increased expression of demand for dispute resolution services from groups not using them before.

\section{Public Perception Indicators}

The HIBP indicative logframe (1/12/2009) already contains provisional indicators based on public perceptions about state courts and community based mechanisms. These have been drawn from The Asia Foundation (TAF) 2008 national survey. This survey does contain a breakdown by province but we were unable to obtain the baseline data for Helmand. Unsurprisingly national level figures bear little relation to Helmand. National figures state that $69 \%$ of people nationally thought shuras and jirgas were effective in 2008 and $52 \%$ thought the state courts were effective. However, a look at the two graphs presented in section 3 from the mapping study indicate a very different picture, particularly with regard to the state courts - the trust level for 'the government system' which includes state courts is less than $5 \%$.

Can responses on perceptions of fairness collected by this study and represented by graphs with percentages in section 3 - be used as a baseline instead? They can - but only in an indicative sense. Although the study achieved a good diversity of respondents (in terms of age, sex, village distribution, and the background occupations of men) the security situation did not allow representative sampling. However, with that proviso, and until the security situation improves, these figures are as good as one is likely to get for perceptions on different dispute resolution mechanisms from women and men in rural Helmand.

Annex 2 on methodology discusses how a more representative sample of respondents could be obtained when the insecurity situation improves. (See 'The Issue of Sampling' under 'Selecting Respondents'.)

\section{Supply Indicators}

Currently in the HIBP framework the number of cases heard by JSC/CCs is given as an indicator of success. However, as mentioned, less case referrals to CCs could indicate that other actors in the system - like Prosecutors or Huquqs - are doing their job effectively and do not need to refer cases to them. The number of cases heard by PRSs may also decrease if the principles of PRSs are heeded (i.e. Security Chiefs don't lock people up when there is insufficient evidence to justify this). Thus a decrease in the number of cases coming to PRSs could be an indicator that PRS principles are being taken on board. In both cases the 'number of cases' indicator is not the best. 
Alternative supply indicators exist. For example, if the intention is to measure the availability of dispute resolution mechanisms to previously excluded groups then two indicators might be:

- the number of women elected to CCs or actively participating in Women's Shura (baseline: 5 , all in Gereshk);

- the number of women standing for/voted onto District Councils (an important future indicator);

- the number of women acting as support intermediaries (baseline: however many ICRWC members are playing this role now);

- If the intention is to measure changes in practice due to increased awareness of human rights by mediators then indicators might be:

- the use of property and assets - and not bad - for settling disputes involving killing (baseline: to be established by polling $\mathrm{CC}$ members before and after a human rights education programme).

\section{Demand Indicators}

The indicator here could be:

- the number of women bringing their cases to public dispute resolution bodies (community or state), including via women intermediaries (baseline: to be established by WADAN in districts)

Summary: The above indicators can also be expressed in terms of the aims of the next phase of UK support. They would then look like this:

\begin{tabular}{|c|c|c|}
\hline Aim & Measurable Indicator & How assessed \\
\hline $\begin{array}{l}\text { 1. Community-based } \\
\text { dispute resolution } \\
\text { mechanisms and state } \\
\text { justice increasingly } \\
\text { trusted and seen as } \\
\text { fair (vs. Taliban justice) }\end{array}$ & $\begin{array}{l}\text { i) Percentage of men and women who say } \\
\text { they trust/see as fair dispute resolution by } \\
\text { community, state, Taliban }\end{array}$ & $\begin{array}{l}\text { Public perception percentages } \\
\text { given in this report. But note: } \\
\text { follow-up assessments must be } \\
\text { with an equivalent group (rural } \\
\text { Helmandis in same districts) }\end{array}$ \\
\hline $\begin{array}{l}\text { 2. JSC/CCs increase } \\
\text { access to justice by } \\
\text { women }\end{array}$ & $\begin{array}{l}\text { i) No. women on CC or Women's Shura } \\
\text { ii) No. women acting as support } \\
\text { intermediaries } \\
\text { iii) No. women bringing their cases to } \\
\text { public bodies, e.g. the Women's Shura, } \\
\text { DG, CC, Huquqs, Prosecutors }\end{array}$ & $\begin{array}{l}\text { Baseline data exists for i) and } \\
\text { ii). WADAN and ICWRC could } \\
\text { establish a baseline for iii). } \\
\text { Subsequent monitoring by } \\
\text { WADAN and ICWRC }\end{array}$ \\
\hline $\begin{array}{l}\text { 3. JSC/CC members } \\
\text { increase their } \\
\text { understanding of basic } \\
\text { rights }\end{array}$ & $\begin{array}{l}\text { i) No. men attending human rights } \\
\text { education programme } \\
\text { ii) Increased knowledge and use of human } \\
\text { rights principles to adjudicate disputes }\end{array}$ & $\begin{array}{l}\text { Before and after interviews with } \\
\text { selected elders participating in } \\
\text { a UK supported human rights } \\
\text { education programme }\end{array}$ \\
\hline $\begin{array}{l}\text { 4. Elders in } \\
\text { communities stop } \\
\text { using women and girls } \\
\text { to settle disputes }\end{array}$ & $\begin{array}{l}\text { i) Proportion of Elders since human rights } \\
\text { education programme saying they have not } \\
\text { used bad in dispute settlement for murder } \\
\text { cases }\end{array}$ & $\begin{array}{l}\text { i) Survey of all CC members in } \\
\text { Helmand to establish baseline } \\
\text { re. bad } \\
\text { ii) Follow up survey with same } \\
\text { elders post human rights } \\
\text { programme }\end{array}$ \\
\hline
\end{tabular}




\section{APPENDIX A}

\section{ADDITIONAL INFORMATION ON TYPES OF DISPUTES AND JUSTICE ACTORS (GARAMSIR, NAD-E ALI, GERESHK, NAWA, MUSA QALA) ${ }^{1}$}

The aim of this annex is to give additional information about types of dispute and the main dispute resolution actors mentioned by respondents in each district. It was not possible to draw these out in the main text for space reasons. The impression given by the mapping study is that Helmand is not wholly homogenous province it comes to how dispute resolution works, it is more like a patchwork of practices and attitudes which are location specific but when looked at overall are far more similar than different. Appreciating the differences as well as the similarities may be important in planning future justice support activities.

This annex, like the rest of the study, concentrates on civil disputes between non-state parties households, neighbours, villages, sub-lineages and so on. It does not focus on disputes with government officers, including the police. ${ }^{2}$ Nonetheless, and although we did not ask about disputes with the police, respondents often gave examples of problems they had with them, including around detentions seen as unfair, physical violence by policemen, abductions of young boys for sex, and demands for money. This needs to be the subject of a separate study.

The main data source for this annex is the mapping study but whenever possible points made by respondents have been checked against the information given in interviews with District Stabilisation Advisers and PRT personnel, PRT reports, District Community Council plans, and other studies.

The first section of this annex deals with types of disputes mentioned for all districts. We then look at each district in turn and summarise some of the additional information given by respondents about justice actors. We take the opportunity of this district level discussion to ask whether there is any evidence from the interviews to say whether bad is increasing or decreasing; the prevalence of this practice seems to vary significantly between districts.

\section{Types of dispute - all districts}

These varied to some extent by district but overall were very similar. Land disputes were the most frequently mentioned type of dispute in all districts. Sometimes the argument was between landowners themselves over land boundaries or ownership; sometimes between landowners and sharecroppers (over boundaries, water or crop distribution) and sometimes between the settled population and kuchis (nomadic groups with flocks using marginal grazing lands) or with recent nakilin (settlers).

Water is a major cause of disputes in areas at the tail end of canals (parts of Garamsir for example) or in areas where there can be water shortages at specific times of year (Musa Qala) but in general disputes over water sharing were mentioned less frequently than disputes over land.

Other types of disputes were similar across the five districts. The most serious were killings accidental or purposive. These normally occurred because of a civil dispute that escalated into violence so that one party was killed. A revenge killing might then occur if the Elders (or the Taliban if they controlled the area) did not step in to prevent it.

The incidence of killings appeared to vary significantly by district. For example, out of 61 respondents in Garamsir only two could recall disputes involving a killing whereas all 50 respondents in Musa Qala reported a killing that had happened within their own extended family or settlement. Because bad is usually given to settle disputes after killings it means that the incidence of bad more or less reflects the incidence of killings. Thus, everyone could give examples of bad in Musa Qala but it was rarely mentioned in Garamsir.

\footnotetext{
${ }^{1}$ Garamsir is also spelt Garmsir; the pronounced spelling is used in this report. Gereshk is the name of district centre of Nahr-e Saraj district; but Gereshk is often used, as here, to apply to the whole district.

2 The issue of complaints against government actors, although not a subject of this study, is important. No matter how much work is done to bolster the ability of community-based dispute resolution and statutory justice systems, and to link them, the behaviour of government actors at district level - the District Governor and Administrator as well as the DCOP and other security chiefs - is a yardstick which ordinary people will continue to use to judge the legitimacy of government.
} 
Unpaid debts were also a cause of disputes. These either arose from debts between shopkeepers or debts arising from individuals speculating on the price of opium, borrowing to buy it but then being unable to pay it back if the price of opium had not risen sufficiently. (Borrowers looked forward to eradication programmes as these would normally push the price up and enable them to repay.)

Theft was reported in all districts. This was mainly small scale and mainly involved theft from stalls and shops, occasionally farm animals. It was often associated with drug use, specifically opium (which one needs to buy, as against poppy which almost anyone can obtain for free as most farmers grow it.)

Disputes between family members were common in all districts and involved different issues. Inheritance issues were a major category, both between brothers and cousins and whenever women claimed their share. As noted in the main report, women traditionally abrogate their share of inheritance to their brothers under Pashtunwali and in so doing are able to claim the protection of their natal family should the need arise. There are two circumstances where they will claim their inheritance rights under Shari'a - first, if they are widowed and need to support themselves and second as married women if they are forced to claim their inheritance by their in-laws (who want the money).

Domestic violence is not a type of dispute as such but women frequently mentioned it. This term covers several things from unequal treatment of wives and their children over work duties or how much they are given to eat, to physical beating, torture, and murder - including so called honour killings. However, despite the very large number of examples given of domestic violence by women, only a few cases had been brought to the attention of public dispute mediators.

The most common type of dispute mentioned by women between themselves was over the share of work within the household. This was particularly mentioned in households where there were cowives who would have different amounts of power, and often varied very significantly in age. Such disputes could be mediated by senior mothers-in-law but also exacerbated by them if they favoured a particular daughter-in-law. Such disputes were mediated internally, either by senior women in the household, or occasionally by senior men.

The most often mentioned problem regarding children (apart from opium use) was early marriage in the case of girls and the abduction and rape of boys, from any age but commonly between 12 and 16 . The early marriage of young girls is mentioned several times in the main report but less attention has been given to the rape of boys. Most examples given involved the police abducting the boys concerned but we have little information about what then happened, whether the family made an official complaint or not and what the outcome of this was. In a few cases, the family concerned did not take action as they felt district government personnel - the DG and DCOP - would take no action, and may subsequently victimise them, as their own men were involved.

\section{Perceived impact of the opium economy on disputes}

It is worth mentioning that throughout the study the opium economy formed a constant background to discussions around disputes. It came up in most interviews with women, who were worried that their husbands or sons might become addicts (some women also become addicts). Drug taking by young men was seen as a problem by many and usually attributed to very limited employment opportunities. It led to men stealing but also to frequent demands on their parents for money. Some women reported their sons would threaten them with an ultimatum: 'Unless you give me money I will go and join the police force or the Taliban' knowing this was sometimes to support an opium or heroin habit. Women took this threat seriously. They associated the Taliban with their sons 'staying until they died' and the police with three dangers: access to opium, sexual exploitation, and the possibility of getting killed. The influence of the opium economy on other justice-related issues was mentioned in the main text, in particular the marriage of very young girls to old men in return for high brideprice payments as a result of profits from poppy production, trade or speculation. 
The rest of this section focuses on justice-related information given by respondents in different districts. A brief introduction to the district is given first, followed by a look at the main dispute resolution actors as perceived by study respondents. Note that this focuses on additional information, i.e. details that it was not possible to give in the main text for space reasons. Concluding each district section is brief note on specific observations on the apparent incidence of bad and other practices affecting women and children.

\section{Nad-e Ali}

Nad-e Ali district centre is just $15 \mathrm{kms}$ north-west of Lashkar Gah on the right bank of the Helmand river. The district came into being relatively recently (1954) as the result of the Boghra canal that opened up an area for irrigated agriculture, and therefore settlement, on what was previously desert steppe. ${ }^{3}$ It was systematically settled by the government of the day (Zahir Shah; Daoud Khan was PM) with land given to different groups of Pashtun nomads. Titles to settled land were all registered with the Amlak (Records Office). Initially the new settlers were given good-sized plots (6+ hectares) and start-up packages (houses, seed, credit etc.) and were settled in seven government constructed central villages. Subsequently other tribes were settled in Nad-e Ali though they received smaller plots; by 1973 plot size had decreased to 2 hectares. The continued development of the irrigation system also bought in wage labourers from other parts of Helmand and the country. Although Nad-e Ali is a mainly settled agricultural district, there are also groups of nomads (Kuchis) who graze their animals on the margins of the irrigated lands.

Today, and due to its settlement patterns and subsequent in-migration, Nad-e Ali is one of the most heterogeneous districts in the province: forty-three different tribes are listed in the Community Council District Plan. As elsewhere, there are significant social and economic divisions in terms of landownership and economic status. The proximity of Nad-e Ali to the provincial capital Lashkar Gah also has an impact on the area - schools and health clinics are available in Lashkar Gah and many government officials reside there.

\section{Justice Actors}

Because most land in Nad-e Ali is registered, and most disputes are around land, the Amlak has an important role here - some disputes do not need to go to the Elders.
"(In land disputes) the Amlak certify the ownership. The Amlak has no formal role but can play one, it depends on the qualification/characteristics of the Director. There was one dispute where they went to the DG and he referred it to the Amlak and at the Amlak they decided the dispute without involving local elders." (Nad-e Ali male respondent)

The District Governor in Nad-e Ali was also referred to many times in relation to land disputes, including as an initial point of contact. It is possible that since the Amlak is located in the district centre, and is crucial reference facility, the DG is used as an early point of contact more often than in areas/districts where land is not registered with the government and/or records are kept at home.

The role of Mullahs and, separately, religious scholars (ulema) was mentioned in Nad-e Ali, particularly with reference to cases involving killings or debt. We noted in the main text that when important ulema are involved in dispute resolution principles of Shari'a are applied. An example of dispute adjudicated by senior ulema is below:

\footnotetext{
${ }^{3}$ The Boghra canal was itself part of the massive irrigation scheme supported by the US in Helmand in the 1950s and 60s. The Helmand Arghandab Valley Authority made large investments and following this, the GIRoA had a policy of resettling different tribes and ethnic groups. (Scott 1980) Today the population is about $80 \%$ Pashtun, $8 \%$ Hazara, $5 \%$ Tajik and $7 \%$ Baluch. (Nade Ali CC District Plan). 
"Two years ago, a farmer, SA, sold $35 \mathrm{~kg}$ of opium on credit to another farmer, HMJ. SA sold at the rate of Rps.10,000 per kg whereas the actual price at that time was $4,500 \mathrm{~kg}$ but because he did not have cash and must buy with credit he bought it at a very high price. HMJ had to pay after one year but when SA asked for the money HMJ said 'I can't pay Rps 10,000 to you as there has been no increase in the price of opium. But I can give you back the opium'. The Elders didn't know what to do so they sent for some Ulema members. They decided if he paid Rps.10,000 it would be like paying interest so they said 'You must accept the returned opium'. So SA took the opium back and the conflict was resolved." (Nad-e Ali male respondent)

Respondents also gave examples of how senior ulema had adjudicated cases involving killings and ensured that financial compensation - and not a girl in bad - had been used to settle the dispute. This is an example of the point made in the main text: senior ulema will ensure that bad is not used as a dispute resolution mechanism. However, local mullahs do not necessarily have the authority to argue for a Shari'a based settlement especially if they are clients of landowning Khans - and the latter prefer to forfeit a daughter than give away land.

The ASOP supported Community Council has played a dispute resolution role in Nad-e Ali since its inception in 2009. As in other districts, whilst acknowledging its justice role several respondents also had concerns about its representativeness and its integrity. They reported that the Nad-e Ali CC had been 'selected' rather than 'elected' (i.e. the electoral college for the first election included too many of the DGs own supporters and was not representative). They also reported a serious dispute that had arisen within the CC itself. Apparently, seed and fertilizer had been given to the $\mathrm{CC}$ for distribution across the district but a particular Elder had seen to it that distribution favoured his area. This led to accusations of malpractice and there was a fight; the Elder killed the man accusing him. At this point, the rest of the $\mathrm{CC}$ intervened and solved the dispute - the accused Elder had to give a substantial amount of money to the dead man's family. (Note, again, they did not use bad, financial compensation was given instead.)

Interestingly, and as noted in the main text, it may have been concerns around the CC that bought so many men together to take part in the second election in April 2010. Certainly, the CC has a high profile in Nad-e Ali and was frequently mentioned by male respondents - although not necessarily in terms of its dispute resolution role.

The other justice actors mentioned frequently in Nad-e Ali were the Taliban. Respondents noted there were large areas of Nad-e Ali nominally under government control but where the Taliban were very active. They said in these areas disputants may choose to go to the Taliban and not the government for two reasons: because they were afraid of the Taliban finding out they are using the government system and because they wanted to ensure the case is heard according to Shari'a. Disputants either wait for the mobile uttaq and/or refer their cases directly to the Judicial Committee of the District Commission. As elsewhere the main advantage of the Taliban justice system, at least for the 'winning' party, is that no one dare gainsay their decisions or reopen the case. Their judgement is final.

Note that the formal justice system is well remembered in this district. In the early years of the Karzai regime, the district centre had a functioning court, a prosecutor, and a huquq. There are expectations that this system could function effectively again if the statutory system becomes more accessible, transparent and accountable.

\section{Bad- is this changing?}

Many respondents could cite instances of bad being used to settle a dispute involving a killing. However, others could also cite instances of where financial compensation had been paid instead. A few respondents said that they thought the incidence of bad was decreasing in Nad-e Ali.

Evidence for a somewhat more liberal attitude in Nad-e Ali (and Nawa) comes from women respondents who gave examples of marriages initiated by a girl or boy rather than by the parents. In Nad-e Ali there was even a case of an unmarried girl getting pregnant, of the story becoming public knowledge, and her parents taking her back. (The woman respondent made the point that even 
though her parents made her have a termination they took her back and did not kill her). The following quotes exemplify this perception of change:

\begin{abstract}
"There is a big change in the treatment of boys and girls who love each other. Sometimes now the families will come together and allow their boys and girls to marry each other. There was a boy and girl that were in love and the boy's family liked the girl's family so they sent a proper proposal and after some negotiation they were married to each other. They live happily now and their families also have a good relationship". (Nad-e Ali woman respondent)
\end{abstract}

\begin{abstract}
"About 13 years back two cousins loved each other. The boy's family sent many proposals but the girl's brothers said no. Now both of them remain unmarried. People say that the brothers are still stopping this relationship and refusing to let them marry. But these two are waiting we think so they can marry one day." (Nad-e Ali woman respondent)
\end{abstract}

Whether a greater degree of decision making over marriage is an indicator of wider changes in attitudes to women or to the independence of young people is difficult to say. However, it made some women feel that change was occurring.

\title{
3. Nawa
}

Nawa district, originally known as Shamalan, is across the Helmand River from Lashkar Gah, in the flood plain. Unlike Nad-e Ali, most of this area has been farmed for centuries as farmers used to draw water from irrigation ditches directly linked to the river. After the Shamalan canal was built (also as part of the Helmand Valley Authority scheme), new settlers also moved in to the district. The population therefore represents both established long-term residents and more recent settlers on government-distributed land.

This settlement pattern has led to more homogenous tribal groupings than Nad-e Ali. Half the population are from just one tribal group - Barakzai, with just three other main groupings: Popolzai, Noorzai and Achakzai. Barakzai Elders dominate the returning government presence in the district centre and the Community Council.

Nawa was largely under Taliban/insurgency control until July 2009. Then, following Operation Khanjari a large American presence remained in the district and the security they provide has allowed households that fled to Lashkar Gah, including government personnel, to start returning. Contact between the PRT and Nawa residents is therefore quite recent - just a year.

\section{Justice Actors}

Nawa is an example of a district with a powerful District Shura that predates the Community Council. This group of 12 senior tribal elders were, and continue to be, Nawa's main powerholders in terms of land ownership, wealth and general influence. ${ }^{4}$ Inevitably, there has been some tension between this group and the new Community Council and in the initial stages the 12 stayed away from the CC and all but one refused to stand for nomination. However, they have apparently seen some of their old power erode and are more interested in the $\mathrm{CC}$ now, particularly since it has become the recipient of project funds. At the time of the study, this group of elders was still meeting fortnightly with the District Stabilisation team and formed a sort of parallel CC.

The fact that the ASOP supported Community Council members are slightly younger than in other districts and do not include the 12 most powerful men in the district was not commented upon by mapping study respondents (this information comes from the Stabilisation Adviser). Rather, the issue they raised around the $\mathrm{CC}$ was again around the integrity of individual $\mathrm{CC}$ members. One woman said she knew that some CC Elders had used their last year's relief distribution of lentils and beans as fodder for their animals rather than giving it to the poorest households. As elsewhere there was a perception that once in power the Elders, who are normally greatly trusted, can become self-seeking if given control over resources, particularly if there are no mechanisms in place to prevent this.

\footnotetext{
${ }^{4}$ Discussions with Nawa Stabilisation Adviser, April 2010 
As in other districts, the District Governor played an important mediation and referral role in disputes. In one specific case the DG got the decisions of the Elders implemented, showing how the 'government' can indeed play a positive role in dispute resolution through backing up decisions made by Elders. This is a good example of how the two systems can link. It is also an example of a widow taking her cases to public dispute mediators.

\begin{abstract}
"A woman's husband died of natural causes. After his death she asked her brother in laws to give her husband's property share to her. They refused. She went to the Elders and they decided what her share should be, but the brothers would not give it. She then went to the DG and he got the decision of the Elders actioned. This was possible because it was a simple case - if you have 30 jiribs land and there are 5 brothers then it should be equally distributed. If the huquq had been there then he would have dealt with it and the court would have decided on the basis of Shari'a." Nawa male respondent.
\end{abstract}

The Marines were also mentioned in terms of their dispute resolution role - a few respondents heard that disputants had approached them as 'honest brokers'. The Marines had an infinitely better image than the British in Nawa. According to respondents, this was because they had caused very few civilian casualties during their military campaign to clear the Taliban. They were also seen as more prepared to engage in foot patrols than the British, which was welcomed.

The Taliban were little discussed as justice actors in Nawa probably because they now control very little territory there. Although seen as honest in the justice sphere there were many complaints about how they extract money in other ways -for example, from Nawa farmers through controlling the Mirabs (water/irrigation managers). All farmers with over 30 jiribs of land reportedly have to pay the Taliban money for water and this is collected by the Mirab. This was given as an example of how the Taliban assert control and extract rents even in government controlled areas.

There is no Amlak (Records Office) in Nawa, which accounts for why it was not mentioned by respondents. In the case of land disputes, disputants had no choice but to go to Lashkar Gah.

\title{
Bad-is this changing?
}

There were very few reports of murder in Nawa, which meant there were also few instances of bad reported. As mentioned in the main text however, this did not imply that women felt they were treated fairly as family members. Women respondents gave many examples of domestic violence although we have no reasons to suspect it is any worse in Nawa than anywhere else.

\section{Musa Qala}

Musa Qala is $130 \mathrm{kms}$ northeast of Lashkar Gah in a foothill region. Unlike Nad-e Ali and Nawa, the US funded Helmand Valley Authority irrigation scheme did not create irrigated land here and today the district continues to rely on indigenous irrigation. This means it has had no new settlers and partly because of this Musa Qala is the most homogenous region of Helmand: $97 \%$ of the population are Alizai. ${ }^{5}$ However, within the Alizai grouping there are two main sub-tribes, the Hassanzai and the Pirzai and these two groups are traditional rivals, a factor that underlies many disputes and affects relationships between the main political players at district government level.

\section{Justice Actors}

The Taliban control the majority of Musa Qala district and respondents had a lot to say about them. Reportedly, the Taliban have an active Judicial Committee under the District Commission. At a lower level, there are the mobile uttaqs (courts) that visit villages on different days and hear cases on request. For minor conflicts, people will normally wait until the uttaq comes. Major conflicts are more likely to be referred to the Judicial Committee, which also sits in different places. If this cannot solve the case then the parties to the dispute send their wakils (representatives) to the Quetta shura where three religious scholars sit and listen to both sides, look at documentation, and make a decision. If

\footnotetext{
${ }^{5}$ This percentage was reported by Scott (ibid) in 1980 and a Tribal Liaison Office publication in 2006. 
the case is major and requires additional evidence, they may freeze the case until all the evidence has been collected.

Respondents reported that they might go to the Taliban even if they lived in the district centre simply because the Taliban may otherwise find out about their association with government and ask them to explain themselves. However, the decision to go to the Taliban first - if local Elders could not resolve the case - also seemed to be because they did not trust the main government actors (DG and DCOP) to be neutral arbiters.

There were several cases of referrals to the Quetta shura given in Musa Qala - though none in any other district. The two brief quotes below show that disputes going to Quetta are usually between larger entities like villages, rather than families or individuals.

\footnotetext{
"The case began with children fighting. This escalated into a battle between two villages. Each village approached different uttaqs so it went to the Quetta shura. The Quetta shura dismissed both uttaqs." (for getting involved in different sides of the case and not being impartial) (Musa Qala male respondent)

"There was a fight between two villages over grazing land. This went to the Quetta shura. The shura said that there were also other claims on this land from other villages so we had better freeze the case until we get more information and can make a decision." (Musa Qala male respondent)
}

Respondents noted that although the Taliban do not use physical punishments for civil disputes they do use them for criminal cases. They gave instances of how people had had their hands cut off when found guilty of theft. There was an ambiguous response to such stories, on the one hand, such punishments stopped crime - a good thing - but they were also seen as brutal.

Respondents also talked about other areas of life over which the Taliban tried to exert control. Men talked about how the Taliban had banned dog fighting (a very popular sport amongst men in Musa Qala as in other parts of Afghanistan) as well as kite flying and pigeon keeping. The first time caught disobeying these injunctions a person apparently got a warning, the second time a physical beating.

Respondents indicated that the Taliban appeared to be less interested in domestic disputes, including 'honour killings' and would refer these to designated Elders and Mullahs. The Elders would very often prescribe that a girl be given as bad. Interestingly however, although bad is against Shari'a, and was explicitly banned by Mullah Omar in 1998, we could find no examples of the Taliban overriding a decision by Elders to use bad. One respondent said they 'avoid noticing such issues'. Another thought there had been a small decrease in the use of bad in Musa Qala since Taliban rule, and due to their current presence.

Some respondents mentioned that Elders and Mullahs in Musa Qala who were not firmly aligned with the Taliban were in a difficult position and were often afraid to take on dispute resolution. Two senior Elders reported that three years ago the Taliban and beaten up a number of senior Elders in Musa Qala and following that incident they were disinclined to hear cases or to become associated with government. As one Elder put it, "If I meet with the government I am threatened."

The threat to Elders or Mullahs who associate with the GIRoA and ISAF forces also helps explain why there is no Community Council in Musa Qala. Although an ASOP Commission visited Musa Qala in July 2009 and invited elders to attend a shura to discuss a CC an insufficient number of Elders came to the event to hold a credible election. Many elders were worried about the threat of retribution from the Taliban. It was therefore agreed to postpone the formation of a CC until security improved and the Taliban threat lessened.

The other dispute mediators mentioned by respondents in Musa Qala (though they probably exist everywhere) were Kalonters. These are agreed leaders of a group of tradesmen or shopkeepers thus copper workers will have a kalonter, as will leather workers. These individuals were mentioned as a primary reference for tradesmen in the bazaar area that had disputes between themselves. There is also one Sayyid in the bazaar who also reportedly resolves disputes between shopkeepers. 
As mentioned, there are no statutory justice actors in Musa Qala; the 'government' is represented by the DG and the District Chief of Police. These two individuals are from the two main sub-tribes and are known rivals. Although both resolve disputes, they were mentioned as mediators relatively rarely. There were several examples of disputes that had first been taken to Elders and been referred at some point to the DG or DCOP, but actually been resolved by the Taliban.

\begin{abstract}
"A person in the bazaar had given some money to another person but when the lender asked him to return it the man denied he had borrowed it. The Elders could not resolve this dispute so they went to the DG who also could not. So the man claiming the money went to the Taliban. They said that the man claiming the money should bring witnesses to prove that he had lent the money and the man denying he had taken it must swear on the Qur'an that this was true. The Taliban resolve the case in this way." Male respondent, Musa Qala.
\end{abstract}

\title{
$B a d-$ is this changing?
}

There was no evidence to suggest that attitudes or practices around women and children's rights were changing in Musa Qala. As noted earlier, almost every respondent could cite a killing and an instance of bad being used to resolve the dispute from within their own family or village. This is despite the fact that, as several respondents noted, bad does not necessarily reconcile families; it can exacerbate tensions, particularly if the young girl is treated badly. In one case given the young woman given as bad killed herself by taking opium and then setting herself on fire. This resulted in greatly increasing the enmity between the families.

Women emphasised that the very restricted lives that they and their daughters live in Musa Qala was not due to the insecurity situation as much as custom. They said that girls are confined to their homes as soon as they reach puberty and are no longer allowed to meet anyone who may be in a marriageable relationship to them (e.g. cousins and other male relatives). If there were to be an affair (one was reported), it was certain that both the girl and boy would be killed. This contrasted to some other districts where only the girl would be killed, or even and on occasions (Nad-e Ali and Nawa) both would spared and a marriage arranged.

\section{GARAMSIR}

Garamsir is located just over $60 \mathrm{kms}$ to the south west of Lashkar Gah. Part of the district is in the canal grid area and the rest is composed of indigenous settlements relying on natural river canals. Water was a major dispute issue in Garamsir - partly because of its location at the tail end of the canal system but also because, as in Nawa, the canals need cleaning; due to the conflict and the way this has undermined traditional ways of getting things done the canals remain clogged, which means people get even less water.

The other main source of disputes was over land and particularly land grabbing of government owned land that has not been officially registered. An estimated $30 \%$ of land in Garamsir district is owned by the state and has not been allocated. Disputes mainly arise between indigenous or early settler families and 'nakilin' - those who have come most recently and unofficially to make a living on unallocated government land. Respondents noted it is difficult to go to government when there are disputes over this land as strictly speaking, no one has a right to cultivate it. Indigenous settlers nonetheless feel they have more rights than the nakilin 'land grabbers'.

Only the northeastern part of the province - known as the snakeshead area because of its shape has been 'cleared' of insurgents and is now held by government and ISAF forces. The southwestern area is held by the Taliban and is a major route for the export of poppy, through Safar, to Pakistan. This area also borders a large refugee and military camp from jihad times (Girdi Zangal - the round forest), which is also used as a transit camp for 'foreign' Taliban, mainly Pakistani but also Arab and other nationalities. 
The largest tribal group in Garamsir is the Noorzai (46\%) followed by Alizai (20\%); there are also a significant number of Popolzai and Baluch and 13 other main tribes. ${ }^{6}$ However, despite this heterogeneity or perhaps because of it respondents emphasised that tribal relations were good in Garamsir and tribal affiliation rarely exacerbated conflicts. Outside the district people referred to Garamsir people as having a mild nature except in their relations with nakilin. The mapping study seems to support this characterisation - Garamsir respondents mentioned only a handful of disputes which had led to violence or a killing. Thus, there were few instances of bad.

\section{Justice Actors}

One frequently mentioned group of justice actors in Garamsir was Sayyids. Sayyids are religious figures seen to be directly descended from the Prophet Mohammed and are therefore seen as tribally neutral. Although Sayyids were mentioned occasionally in other districts as dispute mediators, their role in Garamsir is clearly of a different order. Specific Sayyids were referred to by name and place of residence and were clearly highly revered. ${ }^{7}$ Respondents said they would always go to a Sayyids if the case was serious and their local Elders could not solve it. This was only possible however in an area of government control. In areas of Taliban control, they went to the Taliban. The Taliban were known to dislike the use of Sayyids for dispute resolution because it took away their own power - and possibly because a belief in the spiritual qualities of Sayyids and Pirs (Sufi religious figures) runs counter to the Taliban's fundamentalist ideology.

Although the Taliban attempt to keep a tight rein on justice in areas they control the Taliban justice structure in Garamsir appeared to be less organised than in say, Musa Qala. We cannot verify this but several respondents mentioned the lack of an overall organised Taliban structure. They reported there was no Taliban District Commission in Garamsir and ISAF forces had killed the head of the Justice Committee. Thus, local Taliban Commanders hear cases themselves or refer them to Mullahs they see as supporting them.

The District Governor acts both as a mediator and a referral agent as in other districts. However, although seen by some as a neutral arbiter (he comes from the south of the district and was not associated with tribal infighting) he was referred to relatively little in interviews. Overall respondents in Garamsir spent a lot more time talking about their local Elders and Sayyids rather than the government or statutory system. Baluch respondents rarely mentioned the government/statutory system and said they always tried to resolve disputes within the tribe as this was their custom; they never normally approached outsiders.

Fear of Taliban infiltration including in the district centre explains why some respondents felt that the Community Council in Garamsir was not made up of senior elders, but as they called them 'small white beards'. As one respondent explained:
"You see when we were making the $\mathrm{CC}$ there was still a lot of Taliban in Garamsir including in the snakeshead area and these big White Beards (Elders) didn't want to risk their lives to be on the CC. It is easier to hide the little White Beards as they are not so well known and also the Taliban are not so bothered about them...so the whole of the CC is little White Beards.... and (the problem is) they have no real power."

That said there was evidence from respondents that the JSC does hear and resolve civil cases - over public order, land and irrigation issues. The IDLG (Independent Directorate of Local Government) also has an office in the district centre and keeps records of CC meetings.

\footnotetext{
${ }_{7}^{6}$ These percentages are given in a Tribal Liaison Office publication on Garmasir, May 2007.

${ }^{7}$ Some stories about Sayyids had a mythical quality: "Once one Sayeed was travelling to Kandahar and the car ran out of petrol. The Sayeed put some spit in the tank and the car could take them to Kandahar without petrol".
} 


\section{Bad - is this changing?}

Because bad was mentioned rarely we have no way of knowing if its use is decreasing or not. However, the apparently low incidence of bad in Garamsir should not be taken as an indication that there is a greater awareness amongst men that women and children are individuals with rights. Cases given by respondents as examples suggest deeply conservative-rural attitudes, including towards women.

\section{GERESHK (NAHR-E SARAJ)}

The market centre of Gereshk is $48 \mathrm{kms}$ northeast of Lashkar Gah and is located on the main Herat Kandahar highway. This location means it is an important transport route for trade between Iran and Pakistan. Most tradable commodities go to Kandahar except for poppy that (reportedly) goes to Iran. Except for Lashkar Gah Gereshk has also been better served than other district centres for education; seven of the 21 schools were reportedly open and functioning in July 2009 and a school for girls had been opened in Aab Bazan village (an all Baluch village with a strong sense of tribal identify that has pushed back against Taliban incursions). A number of respondents saw themselves as being more open to new ideas than other districts due to Gereshk's location and history.

As with all other districts, agriculture is the mainstay of the Gereshk economy. The district is situated on the flood plain and is served by the canal network as well as indigenous irrigation. Most areas have plenty of water so it is intensively cultivated. As in other districts, the main crops are poppy, wheat and cotton.

Gereshk's population reflects the heterogeneous character of central Helmand, with a majority of the population being Barakzai but with 13 other tribes and some additional incomers from other parts of the country. Study respondents said that the Taliban control large areas of the district and, as elsewhere, run a parallel Taliban administration. As in Garamsir there was a definite distinction made between 'our' local Taliban and 'foreigner' Pakistani and Arab Taliban.

Note that reportedly Hizb-i Islami are active in Gereshk (which makes sense as it constitutes a largish urban centre and Hizb-i Islami support is mainly urban based). How much we are talking about the Talban and how much about Hizb-i Islami in the section on the Taliban below therefore is not clear; it could be one or both.

\section{Justice Actors}

Local Mullahs were often mentioned as a first point of contact for disputes in Gereshk, particularly in villages where households were clustered around, and associated with, the mosque. Respondents noted that in such villages the mullah is a familiar figure as he collects a meal from each household on a rotational basis. The interviewers (who had family in these villages) noted that even if the mullah does not say very much when a jirga is called to discuss a dispute (perhaps because he is a younger man so leaves the talking to the Elders) he gives the jirga additional legitimacy.

In Gereshk, some respondents mentioned Maliks as second order referral mediators for the community-based system, i.e. as the group one sought out if local mullahs or Elders could not resolve the dispute. Maliks were also mentioned in other districts so their role as dispute mediators is not specific to Gereshk. The term Malik is generally used to refer to the head of a village who interacts with the government (in the past Maliks were responsible for identifying young men for conscription to the army and for collecting taxes). However, we could not gather how important their role is in Helmand today and whether references to them were generic in the sense of 'recognised senior elder that interacts with outsiders' or whether it referred to a man specifically recognised as a leader by the government. (GIRoA has tried to revive the function on Maliks in some areas and that 14 districts of Kabul now have a Malik.)

The District Governor was seen as having an active dispute resolution role and respondents mentioned a number of cases where he had resolved an issue between two parties (over land but also divorce) without referring the case either to the CC or to the statutory system. There was some difference of opinion between men and women about the Community Council, and whether it could be neutral as a decision making body or whether it was too close to the DG. As in other districts, male 
respondents tended to complain that the $\mathrm{CC}$ was not representative. Although the election process was explained to them (the field interviewers had been apprised of how CCs had been set up), respondents still insisted there had been insufficient participation in the compilation of the initial Electoral College list. As one put it, this meant: 'The shura is only a formality in the district and is for the DG and his actions'. However, the Women's Shura members had a different view. They were very positive about the $\mathrm{CC}$ as it had given them an opportunity to be elected, to support women who came to them with cases and to have them heard by the JSC/CC. Their attitude to the DG was also positive; they said there had been opposition to their election from many Elders but he had managed to get their agreement.

Several respondents in Gereshk had complaints against the police, but said there was little they could do to get a case taken up and investigated. In the main report, we mention that newly appointed Prosecutors do not always have the political clout to take on DCOPs over detentions, particularly if they have their own militia at their disposal. This point appears to be particularly relevant to Gereshk. Several respondents mentioned the PRT as a neutral and effective arbiter. The interviews give several examples of help by the PRT to address complaints against the police; two examples are given below. Note that the teller of the first story was not personally involved in the incident. As with all reported stories, the point is clear though the actual event may have been more complicated.

\begin{abstract}
"Two months ago there was a police check point in Saraypol on a bridge. These policemen then went to Aub Bazan and they entered into a house and sexually assaulted women. When the women reported this act to their male members people got very angry and they went to the DG and made a report. The DG said the police cannot go there, it is under Taliban rule so it must have been Taliban or bandits, it cannot be the police. People said if we go to the DG nothing happens, he protects his people, so they went to the PRT commander. The PRT listened and asked people to suggest what should be done. People said these police should be dismissed and the check post should be replaced with the ANA and now they have been replaced. People are satisfied with the PRT commander." (Gereshk, male respondent)
\end{abstract}

"The police came to a village and said 'Each household must pay us Rps. 50,000 or we will destroy your poppy crop. So the villagers went to the PRT and they sorted it out. They stopped the police taking the money". (Gereshk, male respondent)

The Taliban are also significant justice actors in areas of Gereshk district that they control. There were numerous stories of how they intimidate 'their' residents who try to seek justice - or other services - from government. As in other districts, the Taliban also had positive attributes as justice providers. As one respondent put it, "Taliban are decisive and they have the power and ability to enforce their decisions and they don't bribe and they are fair in their decisions".

\title{
Bad- is this changing?
}

There was an interesting difference in opinion between men and some women respondents about whether bad and related practices are changing in Gereshk. Men tended to see Gereshk as a modern place, in touch with the wider world, with bad as a practice of the past. They and government officials interviewed (including the DG) said that bad is decreasing in Gereshk. Several examples were given in support of this point:

\footnotetext{
"In cases of murder people nowadays prefer to pay money or give land rather than give bad. If the family behaves badly with the girl the enmity again reignites. There was a case when two men were sitting on the street and they had a debate about government and the Taliban. The one defending the Taliban took out a knife and stabbed the other man. After two days in hospital this man died. The Elders were summoned and they decided the one who did the stabbing should give 12 jiribs of land to the dead man's family. The documentation was drawn up and the family gave the land. The murderer has not yet returned to the village but when he does no-one will say anything to him, the case has been resolved." (Gereshk, male respondent)
} 
"There was an argument on political issued and one side killed the other and then ran away for five years. But then this man went to the Elders and asked for reconciliation. The leaders decided he should give 18 jiribs of land to the murdered man's family. So now the conflict is resolved."

(Gereshk, male respondent)

However, some women respondents disagreed. They cited numerous cases of where bad had been used to settle disputes involving murder. Indeed, in terms of the number of cases of bad reported by respondents Gereshk was second only to Musa Qala. There were also many cases of honour killings, i.e. girls or women being killed for refusing to marry a chosen man or for running away. We discussed this difference in view about Gereshk with the interviewers. The woman interviewer said:

'Maybe the officials want to say we are more modern here and we have a woman's shura etc.. But when you talk to women then you see that out of (this particular group of) 16 women all but one interviewee could report one or two incidents of bad." She went on: "Generally our traditional practices are anti-women. In some of the cases where there is a dispute between men and women they do deal fairly but they do not deal fairly when it comes to forced marriage, or bad or cases where they give daughters and sisters to pay off a debt. And multiple marriages are also not fair." (Gereshk, woman interviewer)

It is also worth mentioning that Gereshk was also the only district where disputes had arisen over prostitution - incidents of women being forced to become prostitutes by male family members. Gereshk was the only district in which prostitution was mentioned at all. This was not an unexpected finding given its location as a major transport hub.

\section{CONCLUDING POINTS}

This annex has aimed to give additional insights into how respondents perceived and experienced dispute resolution mechanisms in their districts. It is clear that there are local-perhaps even more than district - variations in who people go to when they have a dispute, in how much they trust them and in their attitudes to practices like bad.

The one issue that we would have liked to factor in to this analysis but could not was the political economy, particularly the tribal and political party affiliation of the various justice actors. We are aware that had we done this it would have added another level of analysis and understanding to the processes outlined in this annex and the main report.

A final word on bad- and its use as an indicator. One of the issues this annex brings out is that bad is normally used only to reconcile families after a killing; a girl or woman can also be given to pay off a debt but in this case the practice is not referred to as bad. Two points follow from this:

- We cannot assume that a decrease in the rate of bad (were it to occur in one district or generally) automatically reflects an increased awareness by Elders in women and children's rights. It may simply reflect the fact there are fewer killings in that district;

- Even if bad was stopped absolutely it would not mean that women and children's rights were being respected as it is just one of a raft of practices that depress women and deny them (and children) justice. As noted in the main report, women mentioned the inevitability of forced marriage, multiple marriages and the fact that they have no autonomy, independence or choice in almost any aspect of their lives much more frequently than they mentioned bad. Thus, if the aim is to help women and children achieve their rights, including through the justice system, there needs to be a much wider focus than bad. 


\section{APPENDIX B}

\section{FIELD METHODOLOGY}

The fieldwork for the mapping study took place over eight weeks between $15^{\text {th }}$ March and $17^{\text {th }}$ May 2010. 269 villagers were interviewed, $51 \%$ were women. In the same period interviews were held at provincial and district level with government justice level actors and international partners.

The aim of this annex is to outline the methodology used in this study and to identify lessons learned from using the approach. The focus is on the interviews conducted at village level by the Helmandi interviewing team. The annex may be of interest to other organisations undertaking field research in a conflict environment in a limited time period.

The annex is organised as follows:

1 Study team roles; effects of security situation

2 Identifying interviewers

3 Selecting respondents

$4 \quad$ Steps to ensure data quality

$5 \quad$ Lessons learned

\section{STUDY TEAM ROLES; EFFECTS OF SECURITY SITUATION}

The study team was made up of two international consultants, four senior researchers from CPAU (Cooperation of Peace and Unity) and an 11-person Helmandi interviewing team. The internationals undertook interviews at national and district level with GIRoA, NGO and international justice actors; the CPAU team identified, trained and monitored the local interviewing team and debriefed them on each interview; the interview team (5 women and 5 men plus one woman working in a support role for the women fieldworkers) concentrated on finding and interviewing villagers. A summary of roles is below.

\begin{tabular}{|l|l|}
\hline Team members & Roles/responsibilities \\
\hline International consultants & - Design of study with CPAU - management throughout study \\
- National and provincial level interviews with GoA, international actors and \\
NGOs working in the justice sector \\
- District interview with DGs, DCOPs, Prosecutors, Elders on the \\
Community Councils, and the Stabilisation teams in Gereshk, Garamsir, \\
Musa Qala \\
- Analysis of all field interviews with CPAU \\
- Presentations on findings with CPAU \\
- Writing draft and final report
\end{tabular}


The eleventh member of the Helmandi team - the woman support officer - met the women fieldworkers in CPAU's offices in LKG to debrief them on those aspects of the interviews they found it difficult to convey to the male CPAU researchers, for example, descriptions of domestic violence, 'honour killings' of girls and women, and the rape of young boys. She visited the lead international consultant in Kabul to go through this material.

The security situation had a number of impacts on study design; it also affected how frequently the three groups - internationals, CPAU and the Helmandi interviewers- were able to meet physically. For example, normally CPAU would have used its own researchers as interviewers. However, as nonHelmandis CPAU could not conduct the interviews themselves; they had to identify and train local men and women as researchers (non-locals in Helmand arouse suspicion and if identified as outsiders will be stopped and questioned at check posts and roadblocks). Those without a local connection can be seen as potential insurgents if stopped by the ANP, or as government supporters/spies if stopped by the Taliban. Although CPAU had obtained permission from the provincial and district government administrations to undertake the study their papers would not necessarily be understood by local police at checkpoints - hence the ANP was as likely to detain them as the Taliban.)

Although less likely to be questioned at checkpoints, the local field workers faced several risks. They could not openly carry notes or any other material that might associate them with a foreign-funded activity. They had to choose their interviewing locations carefully, sometimes asking informants if they could interview them in their homes to ensure privacy. The most dangerous part of the job from their perspective was getting to and from Lashkar Gah to debrief the CPAU research team due to the threat of IEDs and roadside bombs. As a result the fieldworkers came in to LKG only three times once for two days of training, once for two days to debrief and receive further guidance after a pilot interviewing period, and then for a further two days to debrief after all the interviews had been completed. This was not ideal as it meant CPAU had relatively few opportunities to give them further guidance and training. The interviewers were all professionals (mainly teachers or health workers) but it was the first time that the women had undertaken a research exercise and only the second time the men had (they had previously worked on the FCO human security study). It was first time for everyone of working on a qualitative study where the questions are mainly open ended with the interviewer's role being to stimulate discussion around central questions; and then record respondent perceptions and experience as near to verbatim as possible.

The security situation also affected how often the CPAU team and the international consultants could get together to translate and analyse the interviews. Although the CPAU team and internationals were based in LKG for much of the fieldwork period - the internationals in the PRT; CPAU in their newly opened LKG offices - the risk of being associated with a foreign or government-funded study made it risky for CPAU to come to the PRT. They noticed their offices were being watched and they themselves followed by a car with no registration plate when they left the office. Meeting at the CPAU office was also risky since the internationals would come with foreign military vehicles and close protection teams. We therefore met at CPAU's offices in Kabul to translate and analyse all the interviews.

Travel difficulties hampered the amount the international consultants managed to achieve at district level. Despite determined efforts by the PRT Rule of Law team and logistics personnel to organise travel to Forward Operating Bases (FOBs) we were unlucky: on six different occasions booked seats to FOBs were not available at the last moment, many days and nights were spent at Camp Bastion hoping for onward transport, and on two occasions trips to FOBs had to be cut short due to the unavailability of accommodation or flights. Although planning to visit all five FOBs the international consultants visited only three. Whilst giving us a necessary flavour of district issues these visits needed to be much longer to add significantly to the information and understanding already held by District Stabilisation and PRT RoL and Governance advisers. 
The period available for the field research was just eight weeks from start to finish. To keep to this timescale, we had to adjust normal qualitative study practice. For example, the pilot phase was merged with the fieldwork proper so that the data collected during training was used as part of the overall data set. This was not ideal as pilot phases are important to get the questions 'right' and to ensure that interviewers understand the overall purpose of the study and can ask appropriate supplementary questions. In retrospect, we do not think this affected significantly the overall results, but a longer time for training would have enabled CPAU to build up the capacity of the local team to a much greater extent than was possible in the time permitted. In addition, we would have preferred to gather the team together in Kabul at the end of the study period for a workshop. This would have given the team the opportunity to meet each other (note that the whole team never once met as a group) and share experiences, do some initial analysis and discuss what we could have done better.

Consultants are always said to want more time and to want it however long they are given. In this situation, extending the field research period over three or four months rather than two would have allowed for a less frantic pace and more reflection, even if the number of working days for each team member increased only marginally.

It is worth mentioning that before we began we had a target of just 180 interviews across the five districts and hoped to get $20 \%-30 \%$ of women interviewees. We achieved 269 interviews, with slightly more women respondents than men. Whilst numbers are still small (between 46 and 60 interviews per district), they exceeded our expectations.

\section{IDENTIFYING INTERVIEWERS}

Recruiting the male interviewers for each district in Helmand was relatively straightforward. CPAU was already working on an FCO study (on human security) that required male researchers and members of this group then became the men's interviewing team for this study. Recruiting women interviewers was made possible though the help of the headmistress of a school in LKG. When she heard about the study she identified women from her teaching staff that she thought would be interested and able interviewers. One woman was identified from each of the five districts. All were good - and better at recording than the men. The fact that women in Helmand must always be accompanied by a male relative when they travel meant we actually needed two people when recruiting women - a woman who was used to travelling and a male relative prepared to accompany her. The men accompanying the women interviewers did not take part in the interviews.

Training was undertaken at the CPAU office in LKG in small groups of twos and threes. This was to protect the interviewers. The CPAU office had only recently been established in LKG and it was felt unwise to bring all 11 new fieldworkers to the building at the same time, lest this attract unwanted attention. Training was undertaken in two phases: an initial two days of briefing, role-play interviews and recording practice followed by a second two-day phase after the first batch of interviews.

Recording was a central aspect of the training because, as noted earlier, after the initial training the interviewers returned to LKG to debrief only twice - after the pilot interviews, and then after the main batch of interviewing. The interviewers needed to write good, clear notes in Pashto in order to capture examples of actual cases to exemplify points made. Many interviewers - and all the women - rewrote each (usually very long) interview out a second time before going through it with the CPAU senior researchers.

Each interview was based around 6-7 main questions. These were slightly different for men and women because we knew that they would have different experiences due to their very different levels of public exposure to dispute mechanisms. Men would know about how public disputes were handled; women would know about the problems women had but could not necessarily bring to a public dispute mediator. Both would have examples of actual cases and how they had been resolved, or not. As noted in the main report, only one of these asked respondents to give a Yes/No answer, the rest asked them to give their opinions, and to back these up with examples. 
The two debriefing sessions for each interviewer were an important time for the CPAU team to clarify issues with the interviewers before transferring the data (still in Pashto) onto the computer. The CPAU senior researcher then summarised the data from each batch of 10-12 interviews under each question heading. This summary was translated into English during the feedback meetings with the lead consultant in Kabul. The international consultant and the CPAU senior researchers spent 12 days going through these summaries (which included all the examples of disputes given by respondents to exemplify points they made) and beginning the analysis.

Interviewing individually worked as well as we could hope. It certainly made for more frank responses that some previous experiences of interviewing in focus groups. Ideally, we would have done both, supplementing the individual interviews with focus group discussions to drill down on apparent similarities and differences in responses, and on priorities for change and action.

\section{SELECTING RESPONDENTS}

We needed the interviewers to find respondents quickly but at the same time ensure a spread of respondents in terms of experience and perceptions. We therefore agreed some principles with the interviewers: they should interview whoever they could find in as safe a place as possible but they should ensure that:

- respondents lived in villages, not the district centre;

- no more than four interviews were to be from the same village (to ensure a wide geographical spread);

- respondents should be reasonably equally divided in terms of age categories $(17-25 ; 26-45$; 46-60) and

- there should be some diversity of background (e.g., men should be a mix of landowners, sharecroppers, wage labourers, shopkeepers, traders and mullahs - with some also being recognised elders).

Most of this was achieved: respondents came from 57 different villages across the five districts; the age categories were reasonably equally represented (with a slight bias towards older age groups) and there was a diversity of backgrounds amongst men.

Achieving a geographical spread was partly achieved by interviewing men in the bazaar area of small towns where they had come to visit from outlying rural areas. Women interviewers first interviewed where they lived or had relatives. Some then looked for a public place where women gathered from surrounding villages. They said that one of the only times women leave their households in rural areas is when they or a female family member is ill. Clinics, where they existed and were functioning, were a good place to interview women because their husbands were normally absent. In rural Helmand, men do not normally take their wives for medical treatment but ask their wives' natal family to take them instead - an honour issue. This was positive for interviewing purposes as husbands and in-laws were usually the people women had problems with and wanted to talk about.

Initially interviews tended to be with men and women from older age groups and not with the 17-25 year old group. During the final stage of interviewing, CPAU therefore asked the interviewers to focus on 17-25 age group for both men and women. This age group now represents a quarter of all respondents. However, although we anticipated there would be differences in responses according to the age of respondents, we found no evidence for this.

The issue of sampling. Overall, the study achieved a good diversity of respondents but we do not claim it is in any way representative. In hindsight, we discussed with CPAU whether it would have been possible to have clustered the population - at least the men - into specific groupings and interviewed an agreed number of men from each grouping. If the parameters of the groupings were known and we had a series of sampling frames (say the number of farmers on a watercourse; the number of teachers in a school; the population attending the Friday prayer of $X$ local mosques; the number of shopkeepers in a town bazaar area), then in principle a sampling technique could have 
been applied to identify individuals from each group to interview. A different but equivalent sampling process would need to be devised for women.

The team could then have returned in a year's time and repeated the exercise using the same sampling technique with each cluster population. This would have at least assured us that we were comparing like with like when looking for trends around say, perceptions of the fairness of different justice mechanisms. However, we agreed that even this degree of purposive sampling is currently impossible given the lack of security in districts, including in government-controlled areas. Inevitably, it would have made the exercise more public - and therefore more dangerous - because we would have needed help identifying the cluster populations and then help again in bringing in or visiting those identified for interview.

\section{STEPS TO ENSURE DATA QUALITY}

In an insecure environment with a team new to qualitative research and a tight schedule experience suggests that the best way to get 'good data' is to have a very few questions and to ask interviewers to record responses as near to verbatim as possible. Verbatim recording means that interviewers cannot fill in an answer themselves, the 'worst' they can do is to omit some of the responses given.

Training is a critical means of quality control. Because CPAU debriefed each individual on their own for two days each time there was a lot of time for supportive feedback and mentoring on weaknesses. For example, one of the interviewers had made very muddled notes of initial interviews but appeared to remember the interviews almost as heard. The CPAU senior researcher therefore asked her to role-play the respondent and he interviewed her, making his own notes on the interview. They then went through their two lots of notes together and identified what was lacking in the interviewer's first attempt.

Monitoring the field research was difficult for CPAU due to the lack of frequent meetings and unreliable mobile phone contact. Interviewers would, but could not always, contact the CPAU team back in Lashkar Gah for advice. We were fortunate to have such a committed and capable group of interviewers.

Summary: We used a small number of questions, verbatim recording and individual training to help ensure data quality. Again, it would have been good to meet at the end so that the field team could share their experiences of interviewing and talk about what worked and what could be done differently, and better, in future.

\section{LESSONS LEARNED}

1. Allow Afghan colleagues to determine levels of risk for themselves and ensure that studies are designed on this basis;

2. Don't see interviewers as extraction agents but as an important resource, whose capabilities need building. This means allowing sufficient time within the study period - and ideally specifically requiring - the group to meet together as a team to share experiences, build awareness of good interviewing practice and understand how they work they have done feeds in to policy debates and programmes;

3. (In future) Help link Helmandi researchers with other groups carrying out research or interested in justice - in this case the DoWA and ICWCR group in LKG commented on how they would have liked to get together with the women interviewers involved this study to discuss findings. (Again, there was insufficient time to allow for this.)

4. Recognise there are a group of Helmandi researchers in the making. Taking this study alone there are now five women and five men in Helmand who have received initial training in qualitative research, plus one women support/facilitator. All said they were keen to build on this initial research experience.

The questionnaires used by the field interviewing teams are below. The language used is based on terms and categories used by respondents. 


\section{JUSTICE MAPPING QUESTIONNAIRE GUIDE FOR MALE INTERVIEWERS AT VILLAGE LEVEL}

This is for MALE INTERVIEWERS who are interviewing:

\section{Ordinary villagers (men)}

2. Elders and others involved as dispute mediators

Location (village and district)

Role/occupation/background:

Approx. age:

Other identity characteristic (e.g. tribe, qawm)

1. What do people do when they have a dispute? Who do they go first and why? Then what happens? Get EXAMPLES AND OUTCOMES

2. Do people ever go to anyone else (not mentioned above)? Under what circumstances do you go to other people? Get EXAMPLES AND OUTCOMES

3. Have there been any changes over time in how the community has dealt with dispute resolution? What about in the Soviet period? During the mujahadeen period? Under the Taliban? And more recently, since Bonn? Has the system got better or not? Get EXAMPLES AND OUTCOMES

4. What are the main types of disputes? LIST all they know and find out which are the most common and least common. (If no-one mentions disputes within households then ask them about this specifically.)

- If murder and accidental killing is not mentioned then ask if there has been a case that they can remember. How was it resolved?

- If they mention bad ask their opinions about it.

5. What sorts of dispute/grievances involve women (including as disputants themselves)? What do women do if they have a problem/dispute - who do they go to first - and then what happens? Get EXAMPLES AND OUTCOMES. Has any woman ever gone to any district level authority (e.g. the woliswal, police) - or has anyone gone on her behalf? Get EXAMPLES AND OUTCOMES

6. What sorts of disputes/grievances involve children and young people up to age 18? (If possible: ask what happens if young boys or girls experience violence or abuse by an older person) EXAMPLE

7. What do you think about the following systems...do you trust them/think they are fair? Why? (Record yes or no but if they say 'it depends' or 'sometimes' write down what it depends on)

- The Wolisi system?

- The Government system? (check definition of 'government')

- The Taliban system? (check if personal experience or not) 


\section{JUSTICE MAPPING QUESTIONNAIRE GUIDE FOR WOMEN INTERVIEWERS AT VILLAGE LEVEL}

This is for women interviewers who are interviewing VILLAGE WOMEN

Location (village and district)

Role/occupation/background:

Approx. age:

Other identity characteristic (e.g. tribe, qawm)

1. WHAT DO PEOPLE DO when they have a dispute? EXAMPLE

- If women are not mentioned ask: And what do WOMEN do when they have a dispute/problem? Get EXAMPLES AND OUTCOMES

2. Do women ever go to ANYONE ELSE (not mentioned above)? Under what circumstances do they go to someone else? Has any WOMAN EVER GONE TO ANY DISTRICT LEVEL AUTHORITY (e.g. the Woliswal, police) - or has anyone gone on her behalf? Get EXAMPLES AND OUTCOMES.

3. What are the MAIN TYPES OF DISPUTES? LIST all they know (e.g. land, inheritance, divorce)

- If murder and accidental killing is not mentioned then ask if there has been a case that they can remember. How was it resolved?

- If they mention bad ask their opinion about it

- What types of dispute/problems are women most concerned about? WHY?

4. What sorts of disputes/grievances involve CHILDREN AND YOUNG PEOPLE UP TO AGE 18? If possible ask:

- What happens if young boys or girls experience violence or abuse by an older person? Get EXAMPLES AND OUTCOMES

- What happens if a woman, girl or boy has to marry someone they don't want to marry? Who will they take this problem to? Get EXAMPLES AND OUTCOMES

5. What do you think about the following systems...do you trust them/think they are fair? Why? (Record yes or no but if they say 'it depends' or 'sometimes' write down what it depends on)

- The Wolisi system?

- The Government system? (check definition of 'government')

- The Taliban system? (check if personal experience or not)

6. In your view is the current way that disputes are dealt with FAIR TO WOMEN AND CHILDREN? What needs to happen for women to say they are fair? 


\section{APPENDIX C}

\section{BIBLIOGRAPHY}

Asfura-Heim, Patricio (2010) The Rule of Law in Helmand Province: An Overview [PowerPoint slides], Helmand Provincial Reconstruction Team, 06 May. Unpublished PRT Document.

Azarbaijani-Moghaddam, S., A. Pinney, A. Masefield, D. Kandiotti and E. Hooper, (2008) Understanding Afghanistan: Poverty, Gender and Social Exclusion, DFID Gender Inequality Final Report.

Barfield, T. Nojumi, N. and Alexander J. (2006) The Clash of Two Goods: State and Non-State Dispute Resolution in Afghanistan. United States Institute of Peace, at http://www.usip.org/ruleoflaw/projects/clash two goods.pdf.

Biesheuvel, Piet (2009) Building security \& justice institutions in conflict-affected environments: Learning from Afghanistan, Seminar Report by Libra and CDS - 8 July 2009

Cordesman, Anthony H. (2009) Shape, Clear, Hold, and Build: The Uncertain Metrics of the Afghan War, Center for Strategic and International Studies, at http://csis.org/publication/shape-clear-hold-and-build-uncertain-metricsafghan-war

Dempsey, J. and Noah Coburn (2010) Traditional Dispute Resolution and Stability in Afghanistan. (USIP United States Institute of Peace), Peace Brief 10, at http://www.usip.org/files/resources/PB\%2010\%20Traditional\%20Dispute\%20Resolution\%20and\%20Stability\%20i n\%20Afghanistan.pdf

Dennys, Christian and Idrees Zaman, (2009) Trends in local Afghan conflicts. Synthesis paper. Cooperation for Peace and Unity (CPAU) at http://www.cpau.org.af/Research/Docs our publications/Trends\%20in\%20local\%20Afghan $\% 20$ conflicts\%20Synt hesis\%20June \%2009\%20Final.pdf

DFID (2004) Non State Justice and Security Systems, DFID Briefing, at http://www.gsdrc.org/docs/open/SSAJ101.pdf

DFID Statebuilding Team (2009) Helmand Institution Building Programme: Final Programme Document, DFID Afghanistan. Unpublished DFID Paper.

Fearon, Kate (2009) Now she goes to school: the work of the Gereshk Community Council Justice SubCommittee, Helmand Provincial Reconstruction Team, Unpublished PRT Paper.

Fearon, Kate (2009) The Cow that Ate the Turban: Report of Focus Groups and Interviews on Attitudes to Formal and Informal Rule of Law Institutions, Helmand Provincial Reconstruction Team, Unpublished PRT Paper.

Fearon, Kate (2010) Proximity, Pragmatism and Pashtunwali: Informal Justice at District Level in Helmand Province, Stabilisation Unit. Unpublished DFID Paper.

Fearon, Kate (2010) Building Community Confidence in the Helmand Afghan National Police (ANP), Helmand Provincial Reconstruction Team, Unpublished PRT Paper.

Fearon, Kate and Sarah Maguire (2009) Prisoner Review Shuras Helmand Province April-October 2009, Helmand Provincial Reconstruction Team, Unpublished PRT Paper.

Fearon, Kate (2010) Prisoner Review Shuras Helmand Province November 2009-March 2010, Helmand Provincial Reconstruction Team, Unpublished PRT Paper.

DFID (2009) Helmand Institution Building Programme Final Progress Document, DFID Afghanistan. Unpublished DFID Paper.

Government of Islamic Republic of Afghanistan (2004) Decree of the President of the Transitional Islamic State of Afghanistan on the Adoption of Electoral Law, Number: 28, 27/05/2004 http://www.afghanweb.com/politics/storage/election law.pdf

Government of Islamic Republic of Afghanistan (2009) Draft National Policy on Relations between the Formal Justice System and Dispute Resolution Councils, 10 November 2009, Kabul, Afghanistan. 
Government of the Islamic Republic of Afghanistan (2009) Sub-national Governance Policy, Directorate of Local Governance (IDLG), Kabul, Afghanistan.

Griffiths, Derek (2010) Helmand Province: Afghan Social Outreach Programme (ASOP), Helmand Provincial Reconstruction Team, Unpublished PRT Paper.

Griffiths, Derek and Kate Fearon, (2009) Serving Country and Village: Counterinsurgency Components of the Afghan Social Outreach Programme (ASOP), Planning Workshop, Provincial Reconstruction Team, Helmand, 15-18 April. Unpublished PRT Paper.

Griffiths, Derek and Kate Fearon, (2009) Nawa Community Council Planning Workshop: A Bridge Between Community and Government, Helmand Provincial Reconstruction Team, Unpublished PRT Paper.

Haider, Huma (2009) Helpdesk Research Report: Gender issues in Afghanistan - VAW and voice, Governance and Social Development Resource Centre (GSDRC), at http://www.gsdrc.org/docs/open/HD594.pdf

Hirst, Fraser (2009) Support to the Informal Justice Sector in Helmand, Helmand Provincial Reconstruction Team, Unpublished PRT Paper.

Lee Walker, Elizabeth (2010) Report on: Culturally-Attuned Governance and Justice in Helmand Province, Afghanistan, International Media Ventures, at https://ronnaafghan.harmonieweb.org/Lists/Submitted\%20Content/Attachments/227/Governance\%20and\%20Jus tice\%20in\%20Helmand\%20-\%20WALKER1.pdf

Lister, Sarah (2005) Caught in Confusion: Local Governance Structures in Afghanistan, AREU (Afghan Research and Evaluation Unit), Briefing Paper, at http://unpan1.un.org/intradoc/groups/public/documents/APCITY/UNPAN021665.pdf

Mildred Caudill (1969) Helmand-Arghandab Valley Yesterday, Today, Tomorrow, Lashkar Gah, USAID, at www.scottshelmandvalleyarchives.org/docs/evl-69-08.pdf

Neamatollah, N., D. Mazurana, and E. Stites (2004) Afghanistan's Systems of Justice: Formal, Traditional, and Customary. Medford, MA: Tufts University.

Rule of Law Team Helmand PRT (2009) Land Registration and Land Dispute Resolution Mechanisms in Helmand Province: A Primer for Coalition Forces and Rule of Law Practitioners, Helmand Provincial

Reconstruction Team, Unpublished PRT Paper.

Scott, R.B. (1980) Tribal \& Ethnic Groups in the Helmand Valley, Asia Society, Occasional Paper 21, at http://scottshelmandvalleyarchives.org/docs/sas-80-01.pdf

Smith, Deborah J. and Jay Lamey (2009) A Holistic Justice System for Afghanistan, AREU (Afghan Research and Evaluation Unit), Policy Note Series, at http://www.areu.org.af/index.php?option=com docman\&task=doc details\&gid=727\&ltemid=26

Smith, Deborah J. (2009) Community-Based Dispute Resolution in Nangarhar Province, AREU (Afghan Research and Evaluation Unit), Case Study Series, at http://www.areu.org.af/index.php?option=com docman\&task=doc details\&gid=726\&ltemid=26\&lang=fa

Smith, Deborah J. and Shelley Manalan (2009) Community-Based Dispute Resolution in Bamiyan Province, AREU (Afghan Research and Evaluation Unit), Case Study Series, at www.areu.org.af/index.php?option=com docman\&ltemid=\&task=doc download\&gid $=725$

Smith, Deborah J. (2009) Decisions, Desires and Diversity: Marriage Practices in Afghanistan, AREU (Afghan Research and Evaluation Unit), Issue Paper Series, at http://www.areu.org.af/index.php?option=com docman\&task=doc details\&gid=631\&ltemid=99999999\&lang=fa

Suhrke, A. and Borchgrevink, K. (2009) Negotiating Justice Sector Reform in Afghanistan. Crime, Law and Social Change 51(2): 211-230. 


\section{APPENDIX D}

\section{GLOSSARY}

\begin{tabular}{|c|c|}
\hline AMLAK & Records Office - holds records of registered land \\
\hline BAD & $\begin{array}{l}\text { The Pashtunwali practice of compensating a murder or accidental killing by giving an } \\
\text { unmarried girl in marriage to the victim's family. }\end{array}$ \\
\hline HANAFI & One of the four Sunni legal schools of Islam. Seen as one of the most liberal. \\
\hline HUQUQS & $\begin{array}{l}\text { State actors from the Huquq (Rights) Department of the Ministry of Justice mandated to } \\
\text { mediate rights cases - over inheritance, land, disputes between family, neighbours, etc. - and } \\
\text { to refer them to the courts if necessary. }\end{array}$ \\
\hline JIRGA & $\begin{array}{l}\text { The traditional decision making body of Pashtun areas of Afghanistan and Pakistan. In } \\
\text { Helmand, jirga refers to meetings held for specific tasks, for instance to solve disputes. They } \\
\text { are different to Shuras that refer to meetings held regularly with a specific membership. } \\
\text { However some respondents used the terms interchangeably. }\end{array}$ \\
\hline $\begin{array}{l}\text { LASHKAR } \\
\text { GAH }\end{array}$ & The provincial capital of Helmand. \\
\hline MALIKS & $\begin{array}{l}\text { Respected Elders - originally the person with authority to enlist young men for the army, } \\
\text { collect taxes and represent the community to the state. }\end{array}$ \\
\hline QUAM & $\begin{array}{l}\text { The group that an individual feels she/he belongs to. Mainly used for sub-tribes and lineages } \\
\text { but can refer to extended family or village. }\end{array}$ \\
\hline $\begin{array}{l}\text { PASHTUN- } \\
\text { WALI }\end{array}$ & $\begin{array}{l}\text { 'The way of the Pashtun'. A code of conduct and honour, the principles of which elders apply } \\
\text { to resolve disputes. }\end{array}$ \\
\hline SAYYIDS & Respected spiritual leaders believed to be descendents of the Prophet Muhammad. \\
\hline SHARI'A & $\begin{array}{l}\text { Islamic Law. The Shari'a provides guidance on how to conduct everyday life based on the } \\
\text { Qur'an and Hadith (the authenticated sayings of the Prophet). }\end{array}$ \\
\hline SHURA & Council with regular membership. \\
\hline ULEMA & Religious scholars trained in Islamic Jurisprudence. \\
\hline UTTAQ & Literal translation is 'room' but here used to refer to Taliban mobile courts. \\
\hline WADAN & $\begin{array}{l}\text { The Welfare Association for the Development of Afghanistan. National NGO with office in LKG } \\
\text { providing logistical support to CCs as part of the ASOP support team. }\end{array}$ \\
\hline WAKIL & Representative, including for disputants in a case \\
\hline WOLISI & $\begin{array}{l}\text { Wolisi means 'People' and the 'Wolisi system' is what respondents called Community Based } \\
\text { Dispute Resolution. }\end{array}$ \\
\hline
\end{tabular}




\section{APPENDIX E}

\section{Terms of Reference for International Consultants Informal Justice Mapping Study: Helmand}

\section{Introduction}

1.1 The UK's work on informal justice in Afghanistan has so far focused on Helmand and has been led by the Civil Military Mission in Helmand $(\mathrm{CMMH}$; the British-led Provincial Reconstruction Team in Helmand). DFID's new Country Plan for Afghanistan envisages a significant increase in DFID's level of engagement on informal justice in Helmand and beyond. Along with the new DFID White Paper Four (Building Our Common Future) which establishes security and access to justice as a "basic service" and central to DFID's approach of improving the lives of the poor, this provides the basis for a DFID lead on informal justice in Afghanistan.

1.2 DFID Afghanistan (DFIDA) owns the policy lead for HMG on informal justice and will, as part of a new Helmand Institution Building Programme (HIBP) take over responsibility for CMMH's work on informal justice. Since its beginning in April 2009, DFID has represented the UK on the Core Working Group for developing a national government policy on the linkages between the informal and formal justice sectors. This comprises key stakeholders from Government, Afghan civil society, the United Nations and the US. This process came out of the Government of Afghanistan (GoA) commitment in the Afghan National Development Strategy to develop a policy on this issue. The first draft of the policy was finalised in November 2009 and as DFID takes over the programme responsibility for informal justice work in Helmand, we want to review the approach and ensure its alignment with the emerging policy.

\section{Objectives \\ 2.1 The study has three objectives:}

a. To map the informal justice sector in Helmand and different types of non-formal justice provision, to include an assessment of the strengths and weaknesses of the identified informal dispute resolution systems (including the identification of practices that may conflict with GIRoA human rights commitments and Afghan laws or may discriminate against or violate the rights of women, children or ethnic minorities). This mapping will include an assessment of relations and interactions with the formal justice sector including referrals between the systems, provisions for oversight and accountability of the systems, diversion from the formal system, review of decisions, collaboration and cooperation between the systems, and the availability of choice for users of the justice systems.

b. To review the current programme of support (including an assessment of its strengths, weaknesses, level of support, and risks) and map points of convergence and departure between the informal system as currently constituted (including approaches fostered by current programming), with/from the proposed national policy. The study will also map and review other informal justice support programmes present in the province and will provide a comparative analysis with the UK programme of support

c. To recommend approaches/actions to increase the compatibility of the informal systems and the current programme of support with the emerging national policy. These approaches/actions should be contextualised to the realities of Helmand and be operationally feasible for potential donors and implementers.

\section{Background}

3.1 HIBP will take UK work on informal justice in Helmand into its second phase. Overall, HIBP aims to address the specific governance challenges of Helmand. It aspires to the goal of a critical mass of the population accepting the legitimacy of Helmand's governing institutions and rejecting unlawful alternatives. Its purpose is to improve the capability, accountability and responsiveness of Helmand's governing institutions to deliver basic services and increase the coverage of informal systems of justice. This mapping study is part of the inception phase of SSBH and will help shape the design of the activities to achieve the specific justice output of the programme: 
Links between informal and formal justice sectors clarified, reinforced and improved; as part of the wider CMMH justice strategy, reducing the use of informal justice mechanisms that are not compliant with Afghan law and international human rights standards (e.g. Taliban justice).

Specifically there is a need to i) establish baselines for what has been achieved so far and ii) review our approach to ensure alignment with the emerging GIROA policy.

3.2 With increased international attention to the informal justice sector and involvement in the Helmand province there is also a need for better understanding of the sector and its relationship with the formal system below the district level. This will help inform the international strategy for engagement with the sector in Helmand.

3.3 Justice sector reform in Helmand has been slow and not well-coordinated and the formal justice sector remains very weak. The weakness of the formal justice sector undermines the nascent sub-national governance structures necessary to improve government performance and legitimacy and provide alternatives to Taliban control and influence. The informal justice sector continues to account for the vast majority of justice delivery in Afghanistan, especially for the rural poor and in provinces where the security is poor. In Helmand, we judge that $90-95 \%$ of disputes are resolved through informal justice mechanisms. Over the last 30 years informal justice mechanisms have been weakened by the policies of successive governments and by ongoing conflict. In this context, nonGIRoA influences have flourished, to the extent where justice is viewed as a key battleground between GIRoA and the Taliban.

3.4 It is clear that neither formal nor the informal sectors are meeting justice needs. Linking the two in constructive and systematic ways and having clear strategies for engagement with both, can build trust in the formal justice institutions, improve the accountability of informal mechanisms, and increase access to justice. This is increasingly being recognised by the Afghan government and the international community. The Government is developing a policy on how to link the informal and the formal justice sectors and international community, specifically the US and the International Security Assistance Force (ISAF), but parts of the UN and the rest of the international community are also engaging. Possible linkages include referrals between the formal and informal systems, review and oversight procedures, diversion from the formal system, improved collaboration between the systems, registration of informal justice decisions in the formal system etc. Of course, the state formally recognising informal justice and the international community supporting informal justice mechanisms are not without risk. There are serious concerns about working with Elders and non-Taliban religious leaders whose decisions may potentially violate human rights, including women's rights, and who draw on a variety of legal systems, religious and customary laws to make decisions that are not always predictable. There is also the risk that the informal system will work better independent of the formal system and the possibility that linking the two will make the informal less effective, as well as the risk that inappropriate interventions may do more harm than good.

3.5 The challenge of linking the informal sector to the formal sector is particularly difficult in Helmand due to the high level of insecurity. The Judiciary, the Chief Prosecutor's office and the Ministry of Justice have cited insecurity as a major reason for them not deploying staff in all districts. Only Laskhar Gah ${ }^{1}$. has a functioning court. There are 9 judges in Helmand ${ }^{2}$ of whom only 3 have any formal legal education training and, as of October 2009, two defence attorneys. At present, only one judge operates outside Lashkar Gah. The CMMH Rule of Law team is currently developing a comprehensive formal sector approach, which includes improving the efficacy of formal justice at district level.

3.6 CMMH continues to support the strengthening of the formal justice sector, but has simultaneously also been piloting an approach to supporting the informal justice sector. In all districts,

\footnotetext{
${ }^{1}$ A city that comprises around $14 \%$ of the provincial population

${ }^{2}$ An area of some $58,000 \mathrm{~km}$ sq and 1.4 million citizens
} 
$\mathrm{CMMH}$ have had to operate in the absence of some of the key formal justice actors such as prosecutors or judges although this is starting to change. The approach aims to i) Build confidence in the Afghan state by encouraging it to recognise the role of Elders and work with them to deliver justice; ii) Increase access to justice; iii) Improve the accountability of informal justice mechanisms; and iv) Establish a platform from which to address the most serious human rights issues, including Baad.

3.7 Our support has been rolled out under the government-led Afghan Social Outreach Programme (ASOP). Specifically, we support two initiatives:

a. Prisoner Review Shuras (currently operating in Musa Qala, Garmsir, Nad e Ali, Gereshk ,and Sangin) which involve official agencies and community representatives to reduce levels of arbitrary detention and ensure that the most serious criminal cases are referred to the formal justice system in Lashkar Gah in a timely manner ; and

b. Justice Sub-Committees of the elected ASOP Community Councils (currently in Garmsir, Gereshk Nad e Ali and Nawa) which - though very new - are resolving disputes and encourage equitable and efficient dispute resolution by other Elders, as well as provide advice and information to communities on basic human rights. They have no power to order imprisonment or financial or physical punishments, and have close links with GIROA through the District Governor.

\section{Scope of Work}

4.1 It is envisaged that one international lead consultant, one locally engaged international consultant and a local partner organisation will deliver this work. It is expected that the lead consultant will sub-contract the local partner organisation. The team will undertake a mapping of the relationship of the informal justice sector with the formal sector, the current status of informal justice sector (including the status and effectiveness of the current $\mathrm{CMMH}$ programme of support) and an assessment of the strengths and weaknesses of the various informal systems including the extent to which the informal sector engages in human rights abuses in at least one local community in all accessible districts of Helmand.

4.2 The international consultant is required to lead a team that will:

- Assess the progress of the CMMH pilot roll-out in the five districts of Musa Qala, Garmsir, Nad e Ali, Sangin and Gereshk and specifically consider the contribution of the CMMH pilot roll-out to:

- improved access to justice;

- increased respect for human rights in shura decision-making, including women and children's rights;

○ improved links to the formal justice sector

- Establish baselines for HIBP logframe and if necessary recommend adjustments to the logframe, including baselines for:

- Approximate number and type of cases referred to the formal justice sector by existing Prisoner Review Shuras;

- Approximate number and type of cases handled by the Justice Sub-Committees;

- The extent and nature of human rights violations by the informal justice sector (including domestic violence and Baad practice);

- The level of capacity of informal justice actors that are involved in resolving community disputes (including details of their strengths, weaknesses, levels of support and legitimacy etc.), with specific reference to their understanding and application of basic legal concepts and human rights standards.

- Assess the compatibility of the current $\mathrm{CMMH}$ approach with the draft national informal justice policy and make recommendations for further aligning the design of the new programme to the said policy, including additional activities. 


\section{Methodology}

5.1 The international consultant will work with a locally engaged international consultant and a local partner research organisation. The local partner will be primarily responsible for data collection in Helmand through their visits to project sites and consultations with national stakeholders (e.g. community members, implementers, Provincial and Municipal governments and line ministries). The international consultants will oversee the data collection and analyse the data.

5.2 The international consultants will be responsible for designing the methodology and for ensuring that the local partner is appropriately trained to apply it. The local partner will as required feed into the methodology design process. The lead consultant will be responsible ensuring that the research team undertakes:

- Pre-field work methodology training for local researchers.

- Desk based review of existing literature on informal justice mechanisms in Helmand, including $\mathrm{CMMH}$ reporting on the informal justice pilot project and the draft informal justice policy.

- Desk based review of existing literature on informal justice in other provinces in Afghanistan where there are significant programmes on informal justice.

- Desk-based review of relevant documents relating to the formal justice system in Helmand.

- Review existing data and as necessary, collect additional data on the existing programme of support, including but not limited to interviews of parties to disputes resolved by JSCs

- Comprehensive data collection in 5 districts in Helmand on linkages between the formal and informal sector and human rights abuses,

- At national level, consultation with DFIDA, FCO Rule of Law Team, Ministry of Justice, Ministry of Women Affairs, Afghanistan Independent Human Rights Commission, US Embassy (State and USAID), US Institute for Peace and other key national and international actors.

- Assessment of the up-scaling of recommended programme design in partnership with other donors, principally the US.

- A Helmand and a Kabul workshop with all relevant stakeholders, as defined by DFIDA and $\mathrm{CMMH}$, to present findings.

5.3 The local partner will visit a selected sample of communities and as required Prisoner Review Shuras (PRS) and Justice Sub-Committees (JSC). Methods of data collection are likely to include individual semi structured interviews and research amongst small focus groups and interview:

- People who have had a case resolved by a JSC, including as many women as possible.

- Relevant partners to these bodies in all districts where they are operational.

\section{Reporting and outputs}

6.1 The recipient of the work will be DFIDA and CMMH, and specifically the HIBP programme team. The team will report to the DFID Justice Adviser and be supported by advisory input from $\mathrm{CMMH}$ Rule of Law Governance and Justice Advisers, DFIDA Governance Adviser and DFIDA Justice Adviser, as well as UK Governance and Rule of Law Strand Lead and the informal justice subteam lead. 
6.2 The main outputs from this assignment will be:

\subsubsection{Inception report/methodology:}

An inception report (max 5 pages) will be produced within 5 days of the start of the assignment. The report will outline the proposed methodology, workplan and time table for conducting the field work as well as the analysis. This will be presented to and agreed by the DFIDA and $\mathrm{CMMH}$.

\subsubsection{Final report on findings and recommendations:}

The final report will be delivered within four months of the start of the assignment. The final report will provide i) an assessment of the achievements of the $\mathrm{CMMH}$ pilot roll-out and establishment of baselines in line with the HIBP logical framework; ii) an assessment of the compatibility with the $\mathrm{CMMH}$ approach with the draft national policy; and iii) a full programme design for an adjusted approach that is further aligned with draft national informal justice policy.

\subsubsection{End of mission presentation:}

Before finalising the report, the team will present a draft report to DFIDA and CMMH. The final report shall be presented to key stakeholders in Lashkar Gah and Kabul which will include, but not be limited to, the Ministry of Justice, the Afghanistan Independent Human Rights Commission, the US Embassy and ISAF.

\section{Time frame}

7.1 The consultancy will commence in February 2010 and the final output must be delivered by end of May 2010.

\section{Background reading}

8.1 A list of the consultant's essential and suggested background reading will be made available in due course.

\section{Team profile}

9.1 A team of up to two international experts and ten local researchers are required for this assignment (two for each district).

9.2 The Team Leader (the lead international consultant) will have at least 5 years experience with informal justice mechanisms in developing countries, ideally in fragile states, countries emerging from conflict and Islamic contexts. He/she will have some experience of designing and / or implementing and / or reviewing programmes that seek to strengthen informal justice mechanisms and ideally also the links between the informal and the formal justice sector. Pastho language skills and familiarity with working with donors in fragile states would be an advantage but are not essential.

9.3 The Locally Engaged International Consultant will have at least three years of experience of conducting research in Islamic contexts, ideally in Afghanistan. It is essential that he/she has demonstrated experience of leading research teams and working with local partners to undertake research. He/she will have experience of conducting research that looks into the relationship between informal and formal justice mechanisms and the assessment of strengths and weaknesses of informal justice systems (ideally experience will include the analysis of the treatment of women, children and other marginalised groups by informal justice systems). Pastho language skills would be an advantage but is not essential.

9.4 The local partner research organisation will have a demonstrated experience of conducting research in insecure environments. 